\title{
Characterization of exhaust emissions from palm oil-based and soybean oil-based biodiesel fueled heavy-duty transit buses
}

\author{
Trampas Jay Efaw \\ West Virginia University
}

Follow this and additional works at: https://researchrepository.wvu.edu/etd

\section{Recommended Citation}

Efaw, Trampas Jay, "Characterization of exhaust emissions from palm oil-based and soybean oil-based biodiesel fueled heavy-duty transit buses" (2009). Graduate Theses, Dissertations, and Problem Reports. 2039.

https://researchrepository.wvu.edu/etd/2039

This Thesis is protected by copyright and/or related rights. It has been brought to you by the The Research Repository @ WVU with permission from the rights-holder(s). You are free to use this Thesis in any way that is permitted by the copyright and related rights legislation that applies to your use. For other uses you must obtain permission from the rights-holder(s) directly, unless additional rights are indicated by a Creative Commons license in the record and/ or on the work itself. This Thesis has been accepted for inclusion in WVU Graduate Theses, Dissertations, and Problem Reports collection by an authorized administrator of The Research Repository @ WVU. For more information, please contact researchrepository@mail.wvu.edu. 


\title{
Characterization of Exhaust Emissions from Palm Oil-Based and Soybean Oil-Based Biodiesel Fueled Heavy-Duty Transit Buses
}

\author{
Trampas Jay Efaw \\ Thesis submitted to the \\ College of Engineering and Mineral Resources \\ At West Virginia University \\ In partial fulfillment of the requirements \\ for the degree of \\ Master of Science \\ in \\ Mechanical Engineering \\ Mridul Gautam, Ph.D. Chair \\ Benjamin C. Shade, Ph.D. \\ Gregory J. Thompson, Ph.D.
}

Department of Mechanical and Aerospace Engineering

\author{
Morgantown, West Virginia
}

2009

Keywords: Bio Diesel, Chassis Testing, PEMS, In-Use Testing, Alternative Fuels 


\section{ABSTRACT \\ Characterization of Exhaust Emissions from Palm Oil-Based and Soybean Oil-Based Biodiesel Fueled Heavy-duty Transit Buses}

\section{Trampas Jay Efaw}

Biodiesel blends offer a renewable energy fueling option for compression-ignition internal combustion engines. Typically, biodiesel blended at or less than $20 \%$ (B20), by volume, will exhibit substantial reductions in diesel particulate matter (PM), while not significantly impacting oxides of nitrogen $\left(\mathrm{NO}_{\mathrm{X}}\right)$ emissions. Additionally, operation on biodiesel blended at B20 levels or less has not been associated with substantial fuel economy penalties.

A study was conducted, wherein two transit buses were utilized to quantify the emissions and performance effects associated with the use of biodiesel fuels, derived from palm oil and soybean oil. Evaluation of the two fuels was accomplished through chassis dynamometer, using West Virginia University's Transportable Heavy-Duty Vehicle Emissions Testing Laboratory (THDVETL) as well as on-board, in-use testing, using WVU's Mobile Emissions Measurement System (MEMS). Performance, fuel economy, and emissions data were collected from both test vehicles, while they were each operated on three candidate fuels - ultra-low sulfur diesel (ULSD - baseline), soybean oil-based B20 biodiesel, and palm oil-based B20 biodiesel. Two buses, unit 04208, powered by a 2004 DDC Series 60 engine, and unit 05108, powered by a 2005 Cummins ISM engine, were utilized for the evaluation. Both vehicles were outfitted with exhaust oxidation catalysts, and the engines employed exhaust gas recirculation (EGR) as a $\mathrm{NO}_{\mathrm{X}}$ reduction strategy.

Vehicle chassis dynamometer tests indicated that B20 blends exhibited 5-7\% improvement in fuel economy, with similar vehicle-averaged reductions in fuel consumption realized for both biodiesel blends. $\mathrm{NO}_{\mathrm{X}}$ emissions measured from the tests for the Cummins bus were actually lower for B20 fuels than for the ULSD baseline fuel. $\mathrm{NO}_{\mathrm{X}}$ emissions recorded for the DDC bus were slightly higher for B20 biodiesel operation (1-2\%). PM was reduced substantially (20$30 \%$ ) for operation on both biodiesels for both vehicles, with slightly higher reductions in PM being realized for operation with palm oil-based B20. Hydrocarbon (HC) and Carbon Monoxide (CO) data were inconclusive due to the presence oxidation catalysts.

During in-use vehicle evaluations, both biodiesel blends exhibited slight differences in fuel economy when compared to ULSD. An anomalous result for the DDC bus was reported, wherein fuel economy for the palm oil-based B20 was 20\% improved over the ULSD baseline. However, brake-specific fuel consumption was consistent with other tests, indicating that much less work was performed by the vehicle during that particular instance of operation. Similar to the results obtained during vehicle chassis dynamometer evaluations, $\mathrm{NO}_{\mathrm{X}}$ emissions were actually reduced when operating with B20 blends for the Cummins bus, and only slightly increased for the DDC bus 


\section{ACKNOWLEDGEMENTS}

First I would like to thank my committee members Dr. Ben Shade, Dr. Gregory Thompson and Dr. Mridul Gautam for not only being professors but also being friends of mine for the past five years. Every one of you have helped me to grow as an engineer both in the classroom as well as in the workplace. Thank you for your devotion to teaching as well as you devotion to me as a graduate student.

I would also like to thank the entire mobile lab crew Jason England, Chris Rowe, Ron Jarrett, Petr Sindler and Curt Lessor, all of you have been like family to me. Working with you guys made things fun, whether it was 2 o'clock in the morning finishing up a project or whether we were a thousand miles from home it was always fun. As I move on in my engineering career I will always remember how to do things in mobile lab style (MLS). I also want to thank the late Gary England who was not only a co-worker but a friend. My heart goes out to the entire England family, Gary is often on my mind and I miss him dearly.

To my family I want to say thank you! Mom and dad thank you for giving me the support and motivation I needed even when things were not going as planned without you none of my education would have been possible. Thank you for being so involved in everything I did throughout the years you will never know how much it meant to me. To Misty, Rylee and Gracelyn - I want to say, you are the best thing that has ever happened to me and thank you being so understanding through the late nights of studying and the days upon days of not being home. I know it was hard on us all, and now we are finally done.

Last but certainly not least I want to thank the most influential person in my entire college career Dan Carder. Dan I learned more from you then anyone else. You took my education personal and pushed me to do better and achieve more. You taught me to think differently about life as well as school. I cannot imagine where or what I would be doing if it was not for you. No matter what the situation was, you were always there to help me through, and for that I want to say thank you. I hope one day I can repay you for all that you have done for me. Dan you truly are one of a kind. 


\section{TABLE OF CONTENTS}



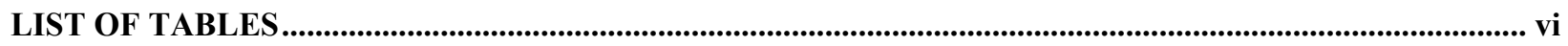



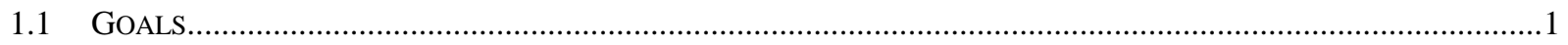

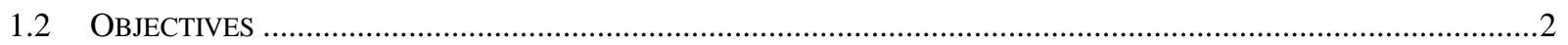

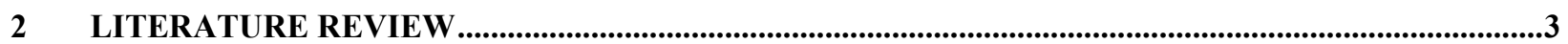

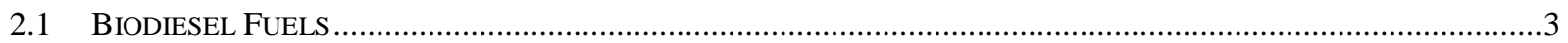

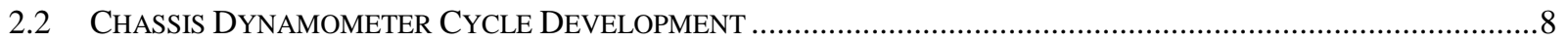

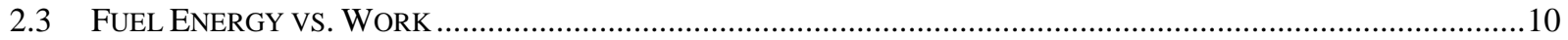

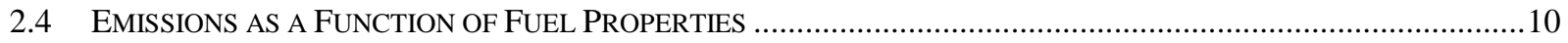





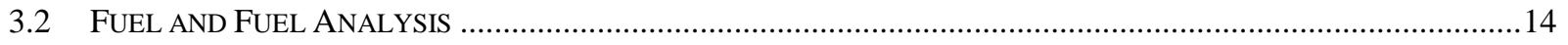

3.3 WVU'S TRANSPORTABLE HEAVY DUTY VEHICLE EMISSIONS TESTING LABORATORY (THDVETL) ............15

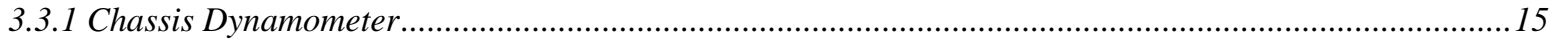

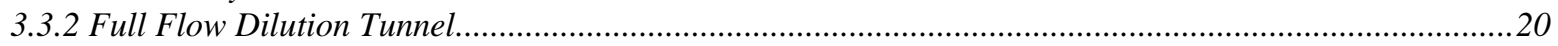

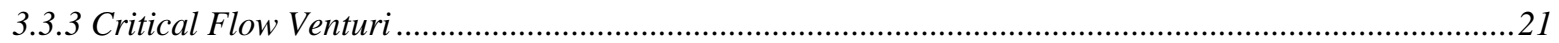

3.3.4 Secondary Dilution Tunnel and Particulate Sampling ...........................................................................21





3.3.7 Gravimetric PM Media Conditioning and Weighing ........................................................................25

3.3.8 Chassis Dynamometer Emissions Testing Procedure ………..............................................................26



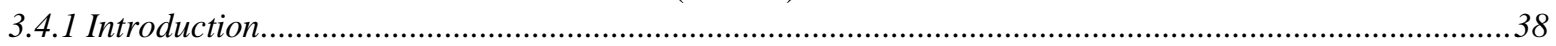

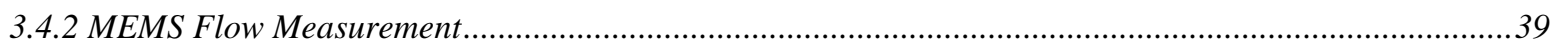

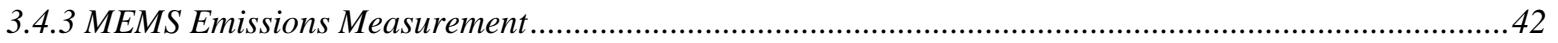

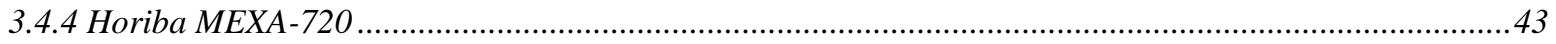

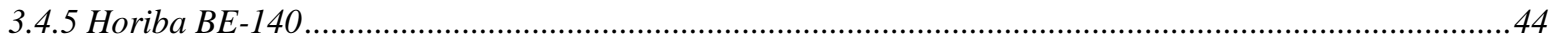

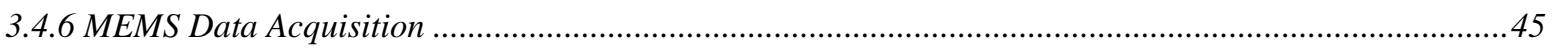

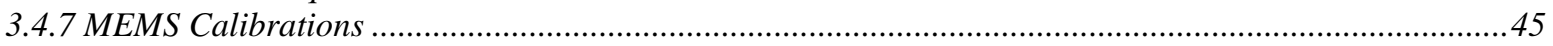

3.4.8 Emissions Test Procedures - On-Road Testing ............................................................................... 49

$4 \quad$ EXPERIMENTAL PROCEDURE .................................................................................................................52

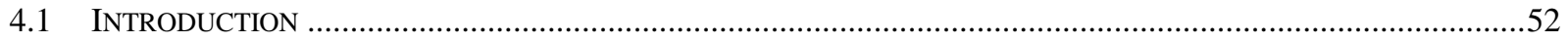

4.2 DEVELOPMENT OF MIAMI-DADE TRANSIT (MDT) CYCLE .....................................................................52

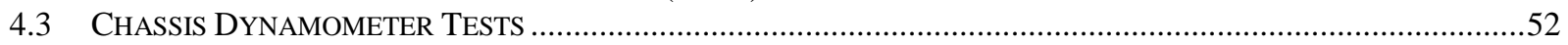



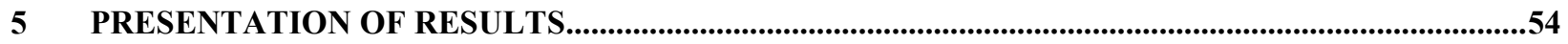

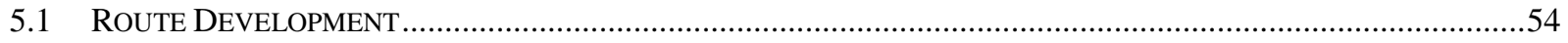

5.2 RESULTS FROM CHASSIS DYNAMOMETER TESTING ..................................................................................59

5.2.1 Chassis Dynamometer Emissions and Fuel Economy Test Results - MDT Cycle ................................60

5.2.2 Chassis Dynamometer Emissions Test Results - Acceleration Cycle …...............................................61

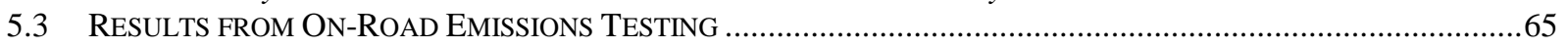

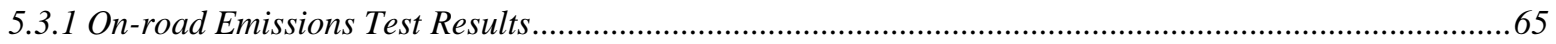

5.3.2 On-road Fuel Consumption Results ..........................................................................................66 




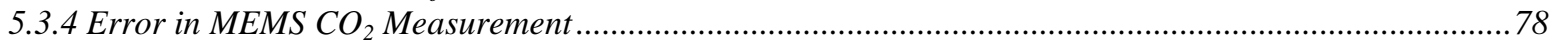

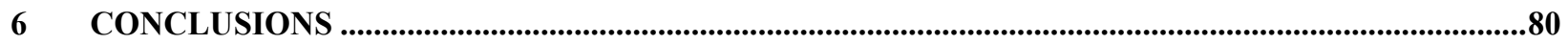

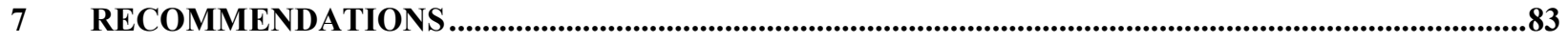

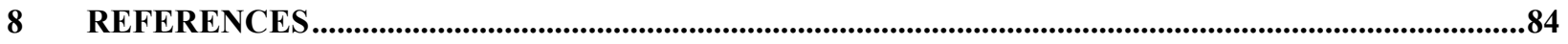

APPENDIX A. SUMMARY SHORT REPORTS OF CHASSIS DYNAMOMETER TESTS ................... A-1 APPENDIX B. SUMMARY SHORT REPORTS OF CHASSIS DYNAMOMETER ACCELERATION

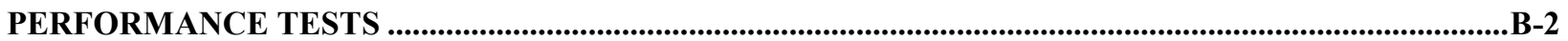

APPENDIX C. SUMMARY SHORT REPORTS OF IN-USE TESTS .................................................... C-2 


\section{LIST OF TABLES}

Table 1 Vehicle Test Weight Information ...................................................................... 27

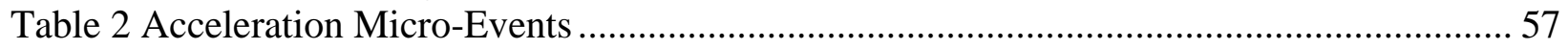

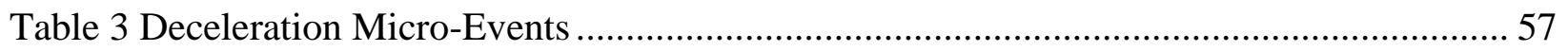

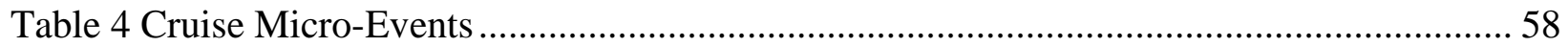

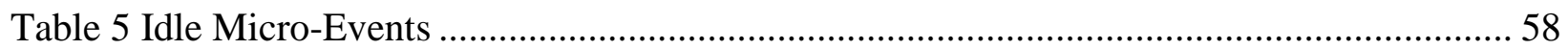

Table 6 Summary of Maximum Accelerations for Bus 04208 - DDC S50 ............................ 64

Table 7 Summary of Maximum Accelerations for Bus 05108 - Cummins ISM 280 ................ 65

Table 8 Averaged On-Road Emissions Results From Bus 04208 - DDC S50 ......................... 66

Table 9 Averaged On-Road Emissions From Bus 05108 - Cummins ISM 280 ...................... 66

Table 10 ECU and Gravimetric Fuel Economy Results for On-Road Tests ............................. 67

Table 11 Estimated Work Over the Test Route ................................................................... 68

Table 12 Summary of Vehicle/Fuel Performance Data from Chassis Dynamometer Tests with



Table 13 Summary of Vehicle/Fuel Performance Data from Chassis Dynamometer Tests with Cummins Bus (Bus 05108).............................................................................. 81

Table 14 Summary of Vehicle/Fuel Performance Data from In-use Vehicle Tests with DDC Bus



Table 15 Summary of Vehicle/Fuel Performance Data from In-use Vehicle Tests with Cummins

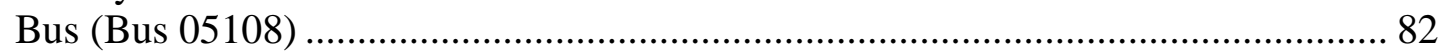




\section{LIST OF FIGURES}





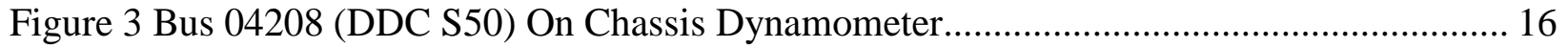

Figure 4 Driveline of the Chassis Dynamometer.................................................................. 18

Figure 5 Vehicle Connection and Support of the Chassis Dynamometer .................................. 19

Figure 6 Schematic of the Annubar Flow Rate Measurement Device......................................... 40



Figure 8 Flow Measurement Transducer Enclosure ............................................................... 41

Figure 9 Emissions Sample Conditioning and Measurement System .................................... 43

Figure 10 Horiba MEXA-720[Error! Reference source not found.] ........................................ 44

Figure 11 BE-140 Gaseous Emissions Measurement Micro-bench [Error! Reference source not

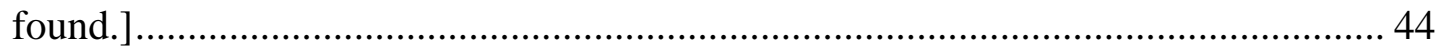

Figure 12 MEMS System Installed on MDT Bus............................................................. 50

Figure 13 MEMS Exhaust Flow Measurement Device and Exhaust Sample Tube Installed on

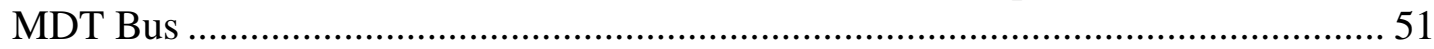

Figure 14 Map of Transit Route Used for MDT Cycle Development ....................................... 54

Figure 15 Speed vs. Time Trace of the Original Transit Route Used for MDT Cycle

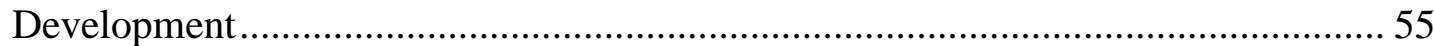

Figure 16 MDT Cycle with Bus Stop Idle Activity Included ................................................. 56

Figure 17 Speed vs. Time trace of the WVU MDT Transient Chassis Dynamometer Cycle ...... 59

Figure 18 Acceleration vs. Time Trace of the Acceleration Test for Bus 04208 - DDC S50 with



Figure 19 Acceleration vs. Time Trace of the Acceleration Test for Bus 04208 - DDC S50 with

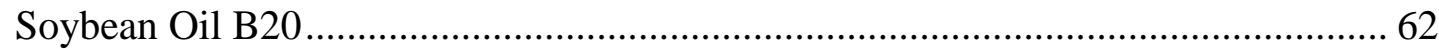

Figure 20 Acceleration vs. Time Trace of the Acceleration Test for Bus 04208 - DDC S50 with

Palm Oil B20 ........................................................................................ 62

Figure 21 Acceleration vs. Time Trace of the Acceleration Test for Bus 05108 - Cummins ISM

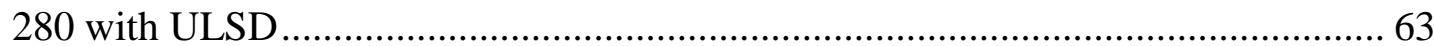

Figure 22 Acceleration vs. Time Trace of the Acceleration Test for Bus 05108 - Cummins ISM

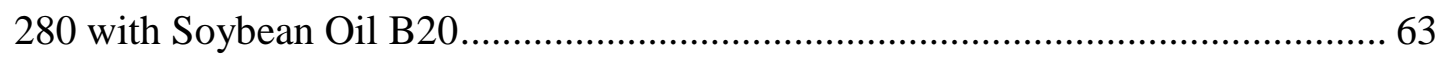

Figure 23 Acceleration vs. Time Trace of the Acceleration Test for Bus 05108 - Cummins ISM



Figure 24 DDC Powered Bus with ULSD - Leg 1 of Test Route .......................................... 69



Figure 26 DDC Powered Bus with Soybean Oil B20 - Leg 1 of Test Route............................ 70

Figure 27 DDC Powered Bus with Soybean Oil B20 - Leg 2 of Test Route............................. 70

Figure 28 DDC Powered Bus with Palm Oil B20 - Leg 1 of Test Route .................................. 71

Figure 29 DDC Powered Bus with Palm Oil B20 - Leg 2 of Test Route ............................... 71

Figure 30 Cummins Powered Bus with ULSD - Leg 1 of Test Route..................................... 72

Figure 31 Cummins Powered Bus with ULSD - Leg 2 of Test Route..................................... 72

Figure 32 Cummins Powered Bus with Soybean Oil B20 - Leg 1 of Test Route...................... 73

Figure 33 Cummins Powered Bus with Soybean Oil B20 - Leg 2 of Test Route...................... 73

Figure 34 Cummins Powered Bus with Palm Oil B20 - Leg 1 of Test Route ............................ 74 
Figure 35 Cummins Powered Bus with Palm Oil B20 - Leg 2 of Test Route

Figure 36 On-road Acceleration Analysis Results for Bus 04208 - DDC S50 with ULSD Fuel 75

Figure 37 On-road Acceleration Analysis Results for Bus 04208 - DDC S50 with Soybean Oil B20 .................................................................................................. 76

Figure 38 On-road Acceleration Analysis Results for Bus 04208 - DDC S50 with Palm Oil B20

76

Figure 39 On-road Acceleration Analysis Results for Bus 05108 - Cummins ISM with ULSD

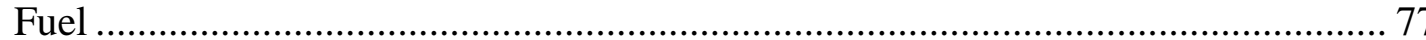

Figure 40 On-road Acceleration Analysis Results for Bus 05108 - Cummins ISM with Soybean



Figure 41 On-road Acceleration Analysis Results for Bus 05108 - Cummins ISM with Palm Oil

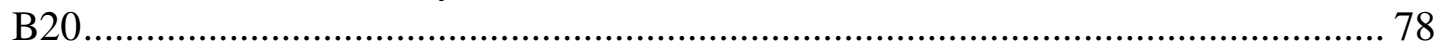

Figure 42 Test Number M190057-2 Loss of $\mathrm{CO}_{2}$ Serial Communication ................................. 79

Figure 43 Test Number M190058-2 Loss of $\mathrm{CO}_{2}$ Serial Communication ................................ 79 
A

B20

CAFEE

CAN

$\mathrm{Cd}$

$\mathrm{CO}$

$\mathrm{CO} 2$

$\mathrm{COV}$

$\mathrm{Crr}$

ECU

$\mathrm{F}$

HFID

FTP75

$\mathrm{g}$

GPS

GVWR

$\mathrm{HC}$

HP

KE

LFE

MDT

MPG

$\mathrm{MPH}$

NOx

PM

Pr

SAE

SG

Std

$\mathrm{t}$

$\mathrm{T}$

THC

ULSD

$\mathrm{V}$

whp

whp/hr mi

WVU
Frontal Area

Biodiesel mixed $20 \%$ volumetrically with ultra low sulfur diesel

Center for Alternative Fuels Engines and Emissions

Computer Area Network

Drag Coefficient

Carbon Monoxide

Carbon Dioxide

Coefficient of Variation

Rolling Resistance Coefficient

Engine Control Unit

Factor for Road Load Equations $\mathrm{F}=1$ for tractor trailer $\mathrm{F}=.085$ for buses

Heated Flame Ionization Detector

Federal Test Procedure 75

acceleration due to gravity

Global Positioning System

Gross Vehicle Weight Rating

Hydrocarbons

horsepower

Kinetic Energy

Laminar Flow Element

Miami-Dade Transit

Miles Per Gallon

Miles Per Hour

Oxides of Nitrogen

Particulate Matter

Road Load Power in Horsepower

Society of Automotive Engineers

Specific Gravity

Standard Deviation

Time

Torque

Total Hydrocarbons

Ultra Low Sulfur Diesel

Velocity

Wheel Horsepower

wheel horsepower per hour mile

West Virginia University 


\section{INTRODUCTION}

In light of decreasing global oil reserves, and subsequently, increasing fuel costs, many industries and government agencies have been exploring the feasibility of alternative sources for their fueling needs. Biodiesel is one of the diesel alternatives that has been realizing an increased interest, largely due to its use of domestic renewable resources and subsequent decreased cost.

Biodiesel is produced from fat or vegetable oil, through a process called transesterification, whereby glycerin is separated from the oil. Neat biodiesel contains no petroleum, but it is traditionally blended with petroleum diesel to create a biodiesel blend, typically at a $20 \%$, or less, volumetric ratio. Pure biodiesel is biodegradable, nontoxic, and essentially free of sulfur and aromatics. Biodiesel is the only alternative fuel for compression-ignition that has fully completed the health effects testing requirements of the 1990 Clean Air Act Amendments. Biodiesel, produced to industry specifications of ASTM D6751, is legally registered with the Environmental Protection Agency as a legal motor fuel for sale and distribution [1].

\section{$1.1 \quad$ Goals}

This study was conducted to evaluate the impact that bio-diesel blends (20\% blends, or B20) had on a vehicle's emissions production, fuel economy, and overall performance and driveability, when compared to commercially available pump diesel (ultra-low sulfur, D2). Specifically, B20 blends of palm oil-based biodiesel and soybean oil-based biodiesel were compared with commercially available ultra-low sulfur D2 diesel (ULSD). The research was conducted by West Virginia University's Center for Alternative Fuels, Engines, and Emissions (CAFEE) at the request of Miami-Dade Transit (MDT). 


\subsection{Objectives}

In order to quantify the impact that the three candidate fuels had on test vehicle emissions, mass emissions of carbon monoxide (CO), oxides of nitrogen $\left(\mathrm{NO}_{\mathrm{X}}\right)$, total hydrocarbons (THC), total particulate matter (TPM or PM), and carbon dioxide $\left(\mathrm{CO}_{2}\right)$ were measured. In addition, comparisons of fuel mileage (miles/gallon) and acceleration performance resulting from operation on diesel-fuel and bio-diesel fuel were made. In order to accurately determine the impact on emissions, fuel economy, and performance, the Miami-Dade Transit (MDT) cycle for chassis dynamometer testing was developed. This provided a more controlled test environment for vehicle performance evaluation, eliminating extraneous variables such as random traffic occurrences and driver prerogatives. Distance-specific ( $\mathrm{g} / \mathrm{mile}$ ) emissions of regulated pollutants and fuel economy were evaluated on WVU's chassis dynamometer-based Transportable Heavyduty Vehicle Emissions Laboratory by exercising the vehicles according to the MDT cycle. Onroad brake-specific (g/bhp-hr) and distance-specific emissions of $\mathrm{NO}_{\mathrm{X}}$ and $\mathrm{CO}_{2}$, as well as in-use fuel economy, were measured by operating the test vehicles on the road over the buses' typical duty cycle. In addition, acceleration performance of the vehicles was quantified for both chassis dynamometer and on-road operation in order to identify any effects of operating with the different fuel blends. 


\section{LITERATURE REVIEW}

\subsection{Biodiesel Fuels}

Since the invention of the first compression ignition engine bio-fuels have been used as an effective source for fueling these engines. The idea of biodiesel was nearly lost for about 20 years as through the 80 's and 90's due to abundance of cheap petroleum, but with increasing petroleum prices and tightened emission standards, biodiesel is now back at the forefront as an alternative fuel. Biodiesel over the life cycle of growing, harvesting, processing and then burning it as fuel, will reduce $\mathrm{CO}_{2}$ emissions by $50 \%$ in its $\mathrm{B} 100$ form or $10 \%$ as $\mathrm{B} 20$ [1].

Transient emissions from No.2 diesel and biodiesel blends in a DDC Series 60 engine were conducted by Colorado Institute for Fuels and High-Altitude engine Research in Denver, Colorado [3]. The scope of the research done in this study was to determine effects of (methyl soyester) biodiesel blends on regulated emissions compared to a baseline No.2 Diesel. This research was conducted in 1996 so ULSD was not the fuel of choice but rather low sulfur diesel. Blends of B20, B35, B65 and neat biodiesel were compared to the low sulfur diesel. Each set of biodiesel tests were bracketed by tests using conventional No.2 diesel to identify drift and correct the data accordingly to provide accurate fuel comparison results. Dilution tunnel flow measurements were obtained using a critical flow venturi (CFV). Gaseous emissions were sampled from the tunnel through two heated lines. One of which was used for $\mathrm{NO}_{\mathrm{X}}, \mathrm{CO}_{2}, \mathrm{CO}$ and the other for hydrocarbons. PM was collected via a secondary dilution tunnel and the flow rate was controlled by two mass flow controllers that controlled the mass flow through the secondary dilution tunnel such that it was proportional to the instantaneous primary dilution tunnel flow rate. Then it was collected by a $70 \mathrm{~mm}$ filter. $\mathrm{NO}_{\mathrm{x}}$ measurements were made via wet Chemiluminesence and Non dispersive infrared analyzers were used for $\mathrm{CO}$ and $\mathrm{CO}_{2}$. Humidity corrections were made to the intake and dilution air to meet the EPA reference level of 75 grains/lb dry air [3].

Reductions in PM, THC and CO were realized with the use of the biodiesel blends. Oxides of nitrogen were increased in all blends of biodiesel. With blends of B35 and less there was a $1 \%$ increase in $\mathrm{NO}_{\mathrm{X}}$ and with blends over $\mathrm{B} 35 \mathrm{NO}_{\mathrm{X}}$ increased substantially with $\mathrm{B} 65$ having a $4 \%$ 
increase in $\mathrm{NO}_{\mathrm{X}}$ and $\mathrm{B} 100$ increasing $\mathrm{NO}_{\mathrm{X}}$ by $11 \%$. PM, THC and $\mathrm{CO}$ were all reduced proportionally to blend with PM being reduced by $66 \%$ with neat biodiesel. THC were reduced by $43 \%$ with the use of B100 and CO was reduced by $47 \%$. Fuel consumption was also found to be a linear function of the blend with the highest fuel consumption being realized with the B100. Power and torque also seemed to be a linear function of the concentration of biodiesel [3].

While soy based biodiesel is the primary bio-fuel in the U.S. because of its availability other researchers are looking at other sources such as coconut oil. A single cylinder $\mathrm{CI}$ engine was operated on Coconut oil methyl ester (CME) with blends of 20\%, 40\%, 60\%, 80\% and $100 \%$ by volume and compared to conventional diesel. The engine was a KIRLOSKAR TV1 which is a 4 stroke $5.2 \mathrm{~kW}$ engine. The biodiesel was made by the researcher through the transesterification process. In this process $1 \mathrm{~kg}$ of coconut oil was converted to $.925 \mathrm{~kg}$ of usable biodiesel. Fuel properties such as density, viscosity, flashpoint and calorific value were measured for each blend of fuel [4].

Emissions and performance measurements were done under steady state conditions at load intervals of no load, $15 \%, 30 \%, 45 \%, 60 \%, 75 \%, 90 \%$ and $100 \%$. An eddy current dynamometer was used for loading the engine. $\mathrm{NO}_{\mathrm{X}}$ measurements were made using a electrochemical analyzer, other gaseous such as $\mathrm{CO}, \mathrm{CO}_{2}$, THC were measured by a single analyzer All data were matched to in-cylinder pressures. The in-cylinder pressure was measured by a high speed data acquisition system in conjunction with a piezoelectric transducer [4].

When the emissions data were matched with the in-cylinder pressure data the biodiesel out preformed the conventional diesel in every aspect including $\mathrm{NO}_{\mathrm{X}}$ emissions where small reductions were realized, with significant reductions in $\mathrm{CO}$, THC and smoke being realized. Unburned $\mathrm{HC}$ were reduced by $25 \%$ while there was a $42 \%$ reduction in smoke. Fuel consumption was slightly higher for the biodiesel which was on the order of $2 \%$ [4].

The use of vegetable oil for fuel also has other not so commonly mentioned benefits such as using waste cooking oil as fuel. A city transit bus was tested on used cooking oil donated from local restaurants in Valencia, Spain, because of Mediterranean diet resulting in a large amount of 
waste cooking oil. Currently this cooking oil is being disposed of in the drains and is causing major problems in the waste water treatment infrastructure. The use of this cooking oil as fuel for buses would be beneficial in many ways [5].

Three different blends of biodiesel, B30, B50 and B70 were compared to conventional diesel fuel. The bus was outfitted with a 2000 Renault VI turbocharged electronically controlled diesel engine. This engine was $300 \mathrm{KW}$ and is certified to the following emissions standards $\mathrm{NO}_{\mathrm{X}}: 5$ g/kWh, HC: $0.66 \mathrm{~g} / \mathrm{kWh}, \mathrm{CO}: 2.1 \mathrm{~g} / \mathrm{kWh}, \mathrm{PM}: 0.10 \mathrm{~g} / \mathrm{kWh}$. The engine was tested over a transit cycle that was created from assumptions and also in-use data of the in use activity of the bus. Many components were considered when developing the route such as mean speed, both including stops, and not including stops and total distance traveled. Parameters of the actual bus stop were also taken in to account such as duration of a bus stop, number of stops, and the time between bus stops. The engine was also tested at four key points of the European Stationary Cycle (ESC). These key locations were at $1200 \mathrm{rpm}$ 100\% load $1500 \mathrm{rpm} 50 \%$ load $1500 \mathrm{rpm}$ 75\% load and $1800 \mathrm{rpm}$ 75\% load. All tests were done on a engine dynamometer with all emissions measurements being collected from raw exhaust [5].

The steady state test results showed large reductions in CO (15-56\%), PM (40\%-78\%), and HC (8\%-50\%) but showed slight increases in the production of $\mathrm{NO}_{\mathrm{X}}(1 \%-6 \%)$. The transit test revealed decreases in all regulated emissions constituents. Most notably $\mathrm{NO}_{\mathrm{X}}$ was reduced by $0.3 \%-1.4 \%$ which is uncommon with the use of biodiesel. Fuel consumption of the biodiesel was higher then that of the conventional diesel in all steady state tests with a significant difference being seen with the use of the B50 and B70. Although the fuel economy is lower with the bio fuels this may not be an issue because the base oil for the biodiesel is waste and would have just been disposed of [5].

Other issues with the use of biodiesel are being explored by researchers such as engine wear and deposit build-up as well as its effects on engine oil. A joint study was conducted by Cummins INC and Chevron Oronite Company LLC to determine the wear effects of biodiesel in CI engines. Neat biodiesel is typical made of fatty acid methyl esters (FAME). These methyl esters are believed to break down the Zinc Dialkyl-Dithio-Phosphate (ZDDP- an additive to reduce engine wear) in crank case oil and increase wear on engine components. Biodiesel has a greater 
surface tension, higher viscosity, and lower volatility than that of No.1 or No.2 diesel. These properties cause biodiesel to form larger droplet sizes and also enables unburned fuel to stick to the cylinder walls. When the biodiesel sticks to the walls of the cylinder it enables the piston rings to scrape off the fuel and deposit it in the engine oil. This happens with conventional diesel also but the droplet size is smaller so a smaller amount of fuel is displaced into the engine oil. When the diesel fuel enters the engine oil it is less likely to evaporate then conventional diesel. Biodiesel has a flatter distillation curve and a higher initial boiling point then that of petroleum diesel due to its long carbon chains. This characteristic means that the temperature required to evaporate a significant amount of the fuel is higher than with petroleum diesel thus more residual fuel remains in the crankcase [6,7].

The oxygenation of the biodiesel causes a break down in the ZDDP additive and also promotes corrosion of metal components. The tests were conducted as a bench test using scientific equipment to determine wear-effects, as opposed to a long duration engine study. Three tests were conducted and included electrical contact resistance (ECR), high frequency reciprocating rig (HFRR) and also a four ball test. Each test was conducted with a percentage of fuel added to the engine oil. The fuel that was mixed with the engine oil was in two states, fresh and aged [6].

After conducting these tests it was concluded that aged biodiesel in concentrations of 5\% or more in the engine oil greatly reduce the lubricating effectiveness of the oil. It was also found that fresh biodiesel actually enhances the lubrication ability of the oil. Another finding in this research was that the biodiesel, aged or un-aged, actually helps suspend soot particles in the oil thus reducing the soot (PM) emitted to the air from the exhaust. It was also noted that the temperature required to regenerate the PM traps on equipped vehicles was much lower then that of the petroleum diesel. It is stated although these results are shown in the laboratory, they need to be verified in real world vehicles and driving conditions [6].

Thermo-King Corporation a division of Ingersoll Rand conducted a study to look at the effects of various engine oils on piston deposit build up from B100 biodiesel. As in the previous study B100 biodiesel is more prone to make it past the piston rings and in to the engine oil because of the increased drop size that is not fully atomized from the injector [6,7]. This causes the larger drops to not fully combust in the short time of combustion. Thus leaving excess fuel to stick to 
the walls of the cylinder and then be carried to the crankcase by the piston rings. It is noted that soybean methyl ester will cause more deposits to form on engine components than other plant oils because of its higher unsaturated fat levels. These unsaturated fat levels cause the fuel to polymerize more quickly than fuel with low unsaturated fat levels. Engine oils can play a significant role in preventing these deposits, lubricating oils with high levels of antioxidants helps to control deposit buildups. Conventional motor oil is low in antioxidants unless additives are employed, while synthetic motor oil is much higher in antioxidants, so it stands to reason that synthetic motor oil would help prevent the buildup of deposits on engine components [7].

This study was conducted with five four cylinder 2.09L 33.9 HP diesel engines. These engines are implemented to run compressors for refrigerated trailers. Engine 1 was fueled with B100 soybean biodiesel and the lubricating oil was conventional fleet grade oil that met API CI-4 performance requirements. The second engine was also fueled by B100 soy but the motor oil in this engine was a premium mineral oil with additives that exceeded API CI-4 requirements. The third engine was again fueled by B100 biodiesel but the engine oil was a semi-synthetic, meaning it was partial conventional oil and partial synthetic oil. This oil exceeds premium mineral oil properties. The fourth engine was fueled by B100 biodiesel and its lubricating oil was a full synthetic which claimed to have the best lubricating properties and has the highest level of antioxidants. The final engine was fueled by petroleum diesel and had mineral fleet grade oil for lubricating. The petroleum fueled engine was used as the control engine to which all others would be compared. Each engine was exercised over the same cycle that was produced from normal operation of this engine. Each engine was run for 1000 hours and an oil sample was taken every 200 hours to provide an understanding of how much fuel was being deposited into the crankcase oil. The results indicated that there was a significant benefit to using synthetic oil when biofuels are implemented. The amount of residue on the piston was much less with the synthetic oils than with the conventional mineral oil. In all cases with the biodiesel the first piston ring was frozen causing even more fuel to leak past the piston. Meanwhile the petroleum diesel fueled engine had no visible residue and both piston rings were free. From this study it can be concluded that engine oil selection can reduce but not fully eliminate residue buildup when a diesel engine is fueled by B100 [7]. 


\subsection{Chassis Dynamometer Cycle Development}

Chassis dynamometer test cycle characteristics play a critical role in the measurement and comparison of emissions and performance for many reasons, the cycle must exhibit a duty cycle that is closely matched to the day-to-day operation of the vehicle being tested. This insures that vehicles, fuels or other variables are analyzed over the operating conditions that they are most likely to see thus providing more insight to real world affects on a given variable. Highway cycles such as the US06 are not as dependent on the day-to-day operation of a vehicle since most highway driving in the U.S. is similar. In contrast urban test cycles are very dependent on the duty cycle as well as the city [8].

The Cape 21 truck usage survey was sponsored by the U.S. EPA in conjunction with Olson Laboratories to provide urban test cycles for heavy duty vehicles. The project took place in New York City as well as Los Angeles to provide the most diverse urban environments available in

the U.S. In each city forty-four vehicles were tested as well as three buses from Los Angeles and four buses from New York [9].

The vehicles that were tested were exercised over their daily route while each vehicle was instrumented to measure engine parameters such as engine speed and torque as well as vehicle speed. From these data Olsen laboratories generated thousands of possible test cycles and then eliminated all of them but four. The cycles were examined by a non-parametric statistical function known as the Kolgomorov-Smirnov test (K-S test). The K-S test was applied to categories of the cycles including acceleration, deceleration, cruise and idle. These categories were defined by the value of acceleration. From these categories the K-S test can reasonably estimate whether or not the generated cycle is representative of the initial data set. At this point, from the cycles that remained, the average speed was examined to find cycles that had approximately the same average speed as the initial data set. The final criteria that had to be met were a visual inspection for density speed plots to insure the generated cycle had the same speed distribution as the original data [9]. 
From this study four urban test cycles emerged, one freeway and one non-freeway from each city. These were then used to create the EPA's FTP 72 and later the FTP 75 engine dynamometer and chassis dynamometer test cycles [9].

As mentioned above, city-to-city variations exist in the operation of vehicles in that city. That is why a chassis test cycle was developed by West Virginia University to simulate Mexico City transit bus behavior. This was done as the first part in an effort to reduce exhaust emissions that has become a major problem in Mexico City in recent years. The cycle that was to be created consisted of three modes namely congested, non-congested and bus rapid transit. The latter of these modes is a theoretical mode that is to simulate an express bus lane to encourage the use of the transit system over personal transportation [8].

Data were collected by a GPS data logger that recorded time, speed, altitude and position. Fifty four hours of useable data were collected to create this cycle. The data were broken down into microtrips that separated low speed from moderate speed. The criteria for this separation was any average speed route falling in the lower $75^{\text {th }}$ percentile was used in the creation of the low speed route while any average speed in the upper $75^{\text {th }}$ was used in the creation of the moderate speed mode. The bus rapid transit mode was derived from data collected from a passenger car on the corridor. Criteria for evaluating the developed test cycles were speed, speed squared, standard deviation of speed and standard deviation of speed squared [8].

The result from this work produced a cycle that was 3000 seconds in length and had 1000 seconds of heavy urban traffic, 1000 seconds of moderate urban traffic and 1000 seconds of corridor that mimicked the Bus Rapid Transit (BRT) once implemented. Each mode from this cycle was different than any other widely used bus cycle. This demonstrates the need for citybased driving cycles that closely correspond to the vehicle behavior in that particular city [8]. 


\subsection{Fuel Energy vs. Work}

Biodiesel, while effective at reducing most regulated emissions, has a lower heating value that is less than that of ULSD. This, in most cases, can translate to higher fuel consumption and decreased power on the order of 8-10\% (depending on the supplier) [10]. Other research done in this area has found that because of the short ignition delay of most biodiesel fuels injection time can be slightly retarded so that the peak cylinder pressures can be reached slightly after TDC. This results in increased thermal efficiency as well as an increase in torque [11].

\subsection{Emissions as a Function of Fuel Properties}

Fuel properties such as the cetane number, density, sulfur content, distillation temperatures and aromatic content vary significantly between petroleum diesel and biodiesel. Biodiesel usual has a high cetane number which shortens ignition delay and thus shortening pre-mix burn as been shown to decrease $\mathrm{NO}_{\mathrm{X}}$ emissions. Biodiesel is also virtually free of aromatics, which are known to reduce PM emissions.

A study of cetane improvers in ULSD and biodiesel fuels was conducted at West Virginia University to determine if the fuel additives could have any beneficial effects on combustion to reduce $\mathrm{NO}_{\mathrm{X}}$ emissions. The reduction of $\mathrm{NO}_{\mathrm{X}}$ with the use of biodiesel fuels is very compelling since one of the drawbacks to biodiesel fuel is the increased $\mathrm{NO}_{\mathrm{X}}$ emissions [12].

Five engines were used in this study ranging in model years from 1991 to 2004. All of the engines were direct injected, turbocharged and intercooled. The emissions measurements were taken from a full scale dilution tunnel to mimic real world tailpipe effects. Two cetane improvers were used in this study namely 2-ethyhexyl nitrate (2-EHN) and di-tertiary butyl peroxide (DTBP). These cetane improvers were compared to a baseline of two ULSD fuels and a blend of B20 soy-based bodiesel. The neat biodiesel was blended to $20 \%$ volumetric proportions with the petroleum base being one of the ULSD baselines A large test matrix was set up for this study but not every fuel combination was tested with each engine [12]. 
Results from this study indicate with the addition of cetane improvers in ULSD fuels, a reduction in $\mathrm{NO}_{\mathrm{X}}$ is seen at low to mid engine loads with no change at high engine loads due to the increased air density at these high loads. An increase in $\mathrm{NO}_{\mathrm{X}}$ production was realized with the use of B20 biodiesel at high engine loads, but a reduction was seen at low engine loads. It is noted that the reduction of $\mathrm{NO}_{\mathrm{X}}$ at low engine loads is most probably related to the fact that biodiesel naturally has a higher cetane number than ULSD. With the use of a cetane improver in the B20 blend only a small increase in $\mathrm{NO}_{\mathrm{X}}$ is seen over the baseline ULSD [12].

A study performed at Texas A\&M University looked at various engine parameters such as volumetric efficiency, brake fuel conversion efficiency, F/A ratio and EGR and how these parameters were affected with the implementation of biodiesel fuel. Moreover these engine parameters were then used to evaluate the performance characteristics and $\mathrm{NO}_{\mathrm{X}}$ emissions of the engine [10].

The research fuel was a B100 neat palm oil based biodiesel and the control fuel was ULS 2007 Certification diesel fuel. The engine used in this study was a four cylinder 4.5 liter direct injected engine with a variable geometry turbocharger (VGT) and EGR. The test matrix for this study was steady state tests at 1400, 1900 and $2400 \mathrm{rev} / \mathrm{min}$ at three different engine torques 50, 150 and $300 \mathrm{ft}-\mathrm{lb}$ for each of the three engine speeds. Engine torque was forced to remain constant even though biodiesel has approximately $4.7 \%$ less energy content than that of petroleum diesel [10].

Over the course of this study it was found that brake fuel conversion efficiency for ULSD and palm oil based biodiesel were virtually the same with only one significant difference coming at $1900 \mathrm{rpm}$ and $300 \mathrm{ft}-\mathrm{lb}$ of torque, where there was approximately a 5\% difference, with biodiesel being less efficient. Due to the increased fueling (due to the lower heating value) that was required to meet the torque demands, biodiesel consistently had a higher F/A ratio than that of the ULSD and due to the VGT, control strategy and the demand for EGR, the mass flow rate of air was also increased with the use of the biodiesel. The combination of these changes resulted in a $20.5 \%$ increase in $\mathrm{NO}_{\mathrm{X}}$ production with neat biodiesel [10]. 
A study conducted at Southwest Research Institute in conjunction with Cummins Inc. looked at fuel properties and their effect on exhaust emissions. The study was designed to evaluate the effects of varying fuel properties, such as the cetane number and aromatic content of the fuels, and how these factors directly affect exhaust emissions. Other factors such as EGR and injection pressure were also examined to determine their effects on exhaust emissions [13].

A Caterpillar 3176B was used with two different experimental setups. The first engine set-up had no EGR and was compliant to 1994 emissions levels and the second set-up employed cooled EGR and was intended to be compliant with 1998 standards which it did not meet. The cetane number was varied from 35 to 55 while the aromatic content was varied between 10 and $30 \%$ and poly-aromatics ranged between $1-7 \%$. The fuels that were derived to form these conditions were tested on both engine set-ups [13].

The results from this study found that the major factors that affect exhaust emissions lean heavily towards engine technology. The engine set-up with EGR produced less $\mathrm{NO}_{\mathrm{X}}$ and $\mathrm{HC}$ than the non-EGR engine but CO and PM increased with the implementation of EGR. It was found that the fuel properties had very little effect on regulated emissions. There was weak correlation between $\mathrm{NO}_{\mathrm{X}}$ and $\mathrm{HC}$ with varying aromatic content. The dominant factor for $\mathrm{NO}_{\mathrm{X}}$ production was found to be the adiabatic flame temperature [13]. 


\section{EXPERIMENTAL SETUP AND TEST PROCEDURES}

\subsection{Description of Test Vehicles}

MDT identified two candidate vehicles to use for the fuels evaluation program reported herein. These vehicles were selected as most representative of the majority composition of the current MDT revenue fleet. A 2004 NABI (North American Bus Industries), powered by a 2004 DDC Series 50 (MDT Bus Number 04208), and a 2005 NABI, powered by a 2005 Cummins ISM (MDT Bus Number 05108) were used for the entirety of the test program. Both vehicles had routine maintenance performed prior to test usage (oil change, oil and air filter, and general safety inspection), and the vehicles' electronic engine control module (ECM) was interrogated to verify that no error codes were present. The buses that were tested can be seen in Figure $1 \&$ Figure 2 .

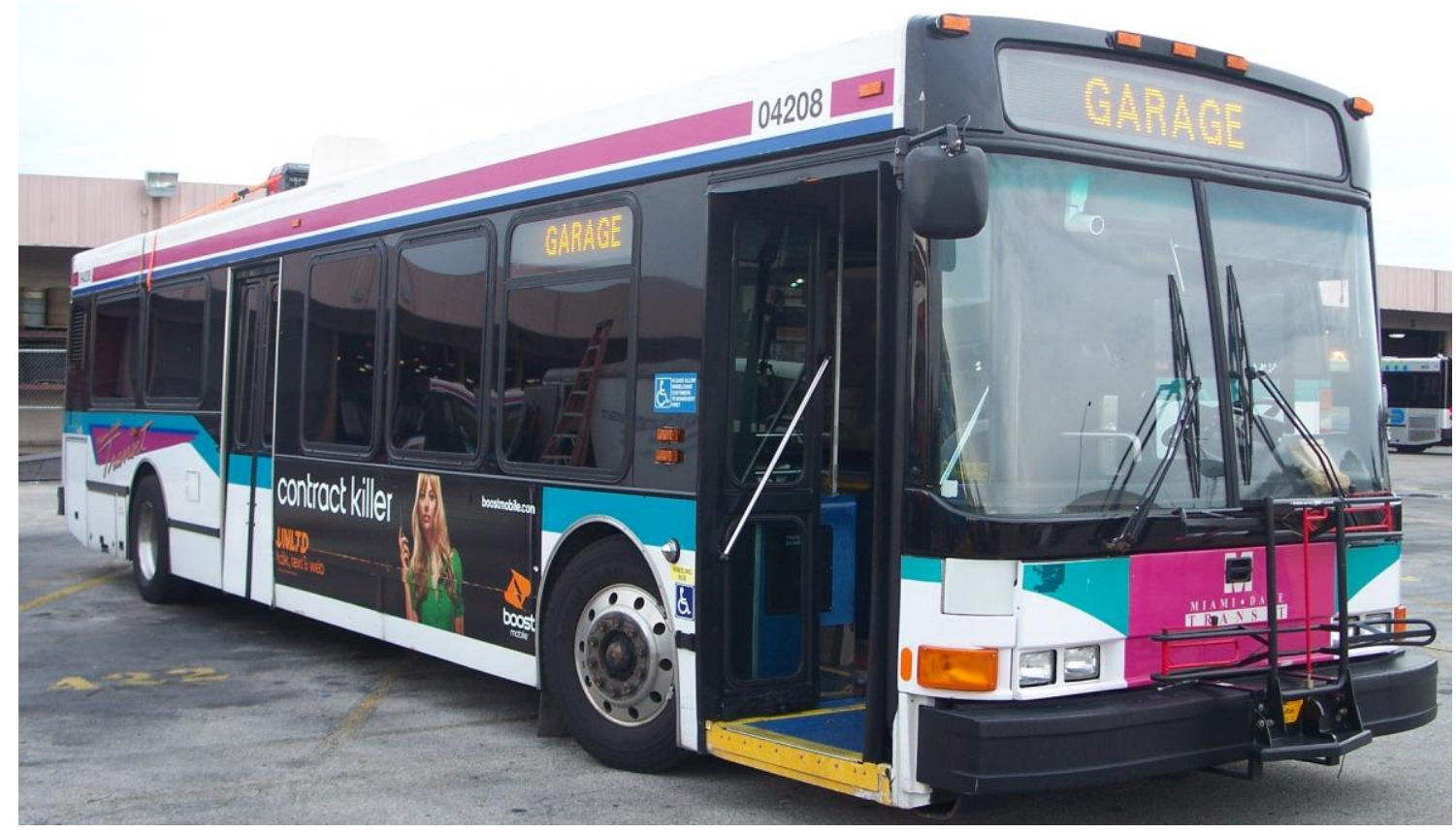

Figure 1 MDT Bus 04208 DDC Series 50 Engine 


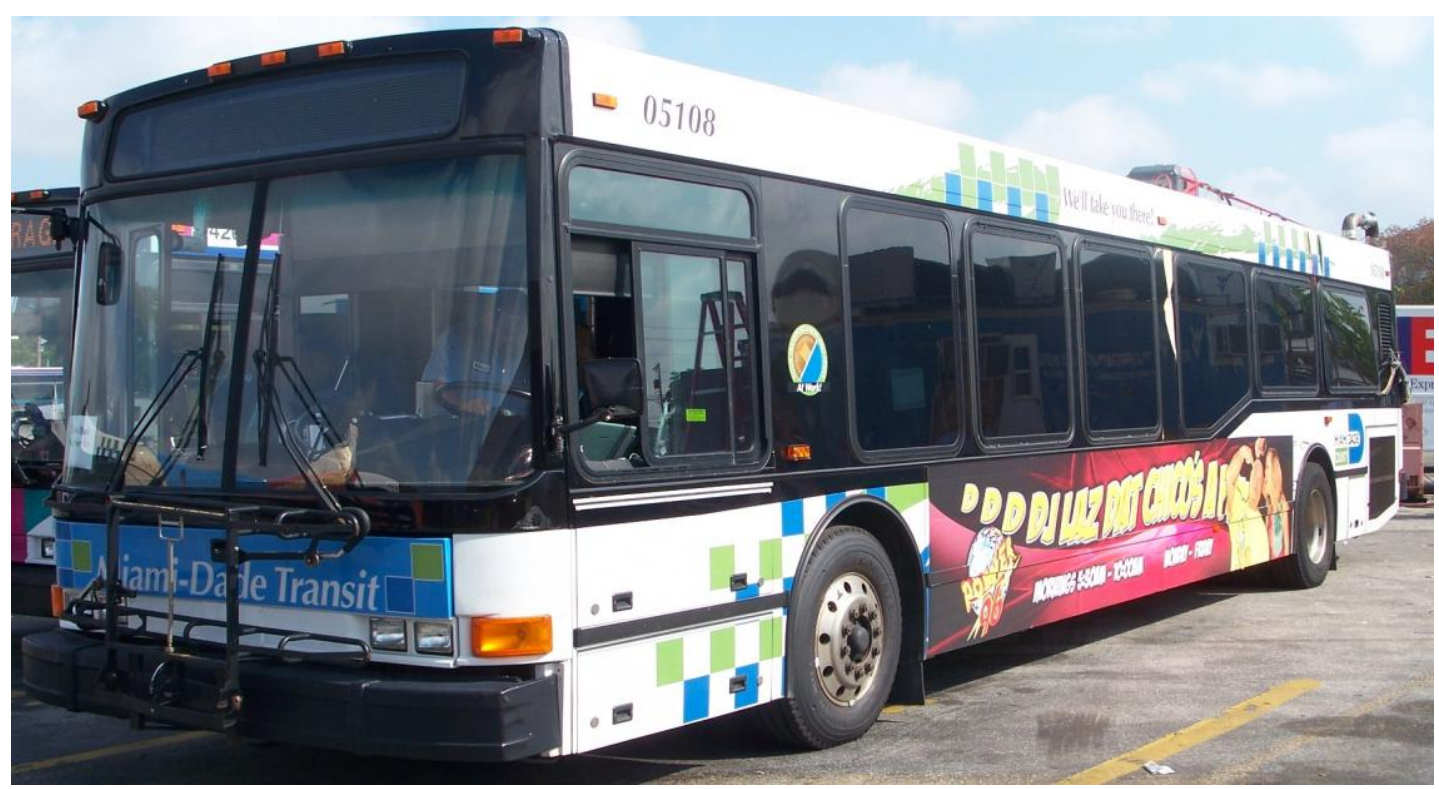

Figure 2 MDT Bus 05108 Cummins ISM 280 Engine

\subsection{Fuel and Fuel Analysis}

Both test vehicles were operated on fuel provided by MDT. The ULSD was operated in neat form, and provided the control fuel (baseline) for the test program. The B20 blend of palm oilbased biodiesel was pre-blended from the fuel supplier. The B20 soybean oil-based bio-diesel had to be blended on sight from the same ULSD that was used for the baseline tests. In order to provide an accurate volumetric blend, the B20 was mixed according to mass weight. After determining the specific gravity with a hydrometer, and recording the fuel temperature, the volumetric blend ratio was calculated on a mass basis. Certificates of analysis of the neat biodiesel components of the palm oil and soybean oil B20 blends are available from MDT. Fuel samples of the three test fuels were collected. When fuel types were changed during the program, the vehicles' fuel systems were purged of the existing fuel, and then operated on the new candidate fuel for a significant time in order to ensure that the correct fuel was being combusted during the respective tests. 


\subsection{WVU's Transportable Heavy Duty Vehicle Emissions Testing Laboratory (THDVETL)}

WVU's Transportable Heavy Duty Vehicle Emissions Testing Laboratory was used for the chassis dynamometer testing. The emissions sampling, sample conditioning, and analysis, by this laboratory system have been utilized for studies funded by the California Air Resources Board (CARB), National Renewable Energy Laboratories (NREL), U.S. Department of Energy (DOE) and other Federal, State and commercial entities. Emissions sampling and measuring systems were designed, and associated calculations were derived from procedures outlined in the CFR 40, Part 86, Subpart N where applicable. This mobile laboratory consists of a chassis dynamometer, which is used for driving the test vehicle on desired duty cycles, and an instrumentation trailer that serves as the analytical component of the system. Although federal regulation to not give guidelines for chassis dynamometer testing, laboratory quality instrumentation, including a full flow primary dilution tunnel, secondary tunnel for particulate sampling, regulated and unregulated gas emissions sampling trains, data acquisition, and control systems were designed and operated according to applicable procedures and recommendations of CFR 40, Part 86, Subpart N. A description of the various laboratory subsystems are discussed in the following sections.

\subsubsection{Chassis Dynamometer}

The chassis dynamometer test bed consists of rollers, hub adapters, and a load simulation system constructed as a tandem axle semi trailer. Four hydraulic jacks on the chassis dynamometer test bed are used for installing and removing the tag-axle tandem sub frame assembly. The various components of the chassis dynamometer are discussed in detail below. 


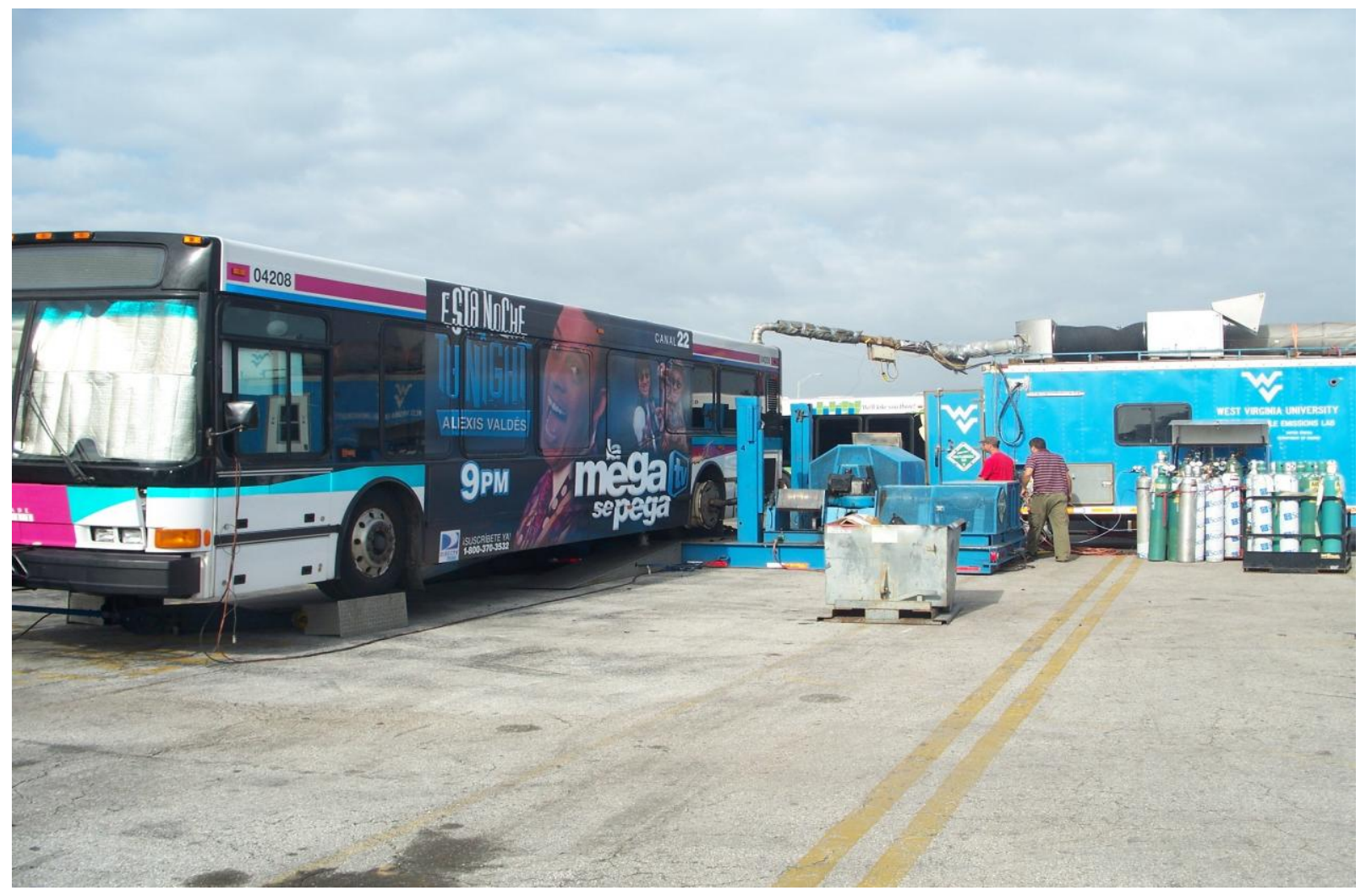

Figure 3 Bus 04208 (DDC S50) On Chassis Dynamometer

\subsubsection{Rollers}

The chassis dynamometer has two sets of two paired rollers to accommodate tandem axle vehicles. The rollers are 36" wide and separated by a 3' gap between them and are connected in the center by a coupling to evenly distribute power to both wheels in case of inadequate surfaces at testing locations. Each roller is 12.6 " in diameter, no power is supplied to the inertia simulation through the rollers; they are only to support the load of the vehicle.

\subsubsection{Hub Adapters}

Hub adapters are the link between the drive axles and the simulated inertia, and all wheel power is applied through them. The adapters are 21.6 " in diameter and constructed of $1 / 2$ " aluminum. The hub adapters are attached to a retrofitted rim with stud running through the rim and bolting to the hub adapter. The other side of the hub adapter is connected to an 1810 series driveshaft 
that transfers the power through the load cells and to the simulated inertia. The hub adapters can be seen in Figure 5.

\subsubsection{Load Simulation System}

The load simulation system consists of two flywheel assemblies, two eddy current power absorbers, two AC electric drive/absorption motors, two speed and torque transducers, double differentials and universal couplings on either side of the vehicle to be tested as shown in Figure 4 below. The power from the vehicle's drive axle is transmitted to the flywheel assembly and

power absorbers. A splined shaft is connected to the speed and torque transducer. The speed and torque transducer is capable of providing the data logging computer with time varying output torque at a rate of $10 \mathrm{~Hz}$. The torque transducer drives a second shaft via companion flange. This shaft transfers power to a right-angle speed increasing drive, a double reduction differential with a ratio of 1:3.65 which drives the flywheel assembly and a second differential. The second differential with a ratio of 1:5.83 drives the eddy current power absorbers and the $20 \mathrm{hp} \mathrm{AC}$ motors.

\subsection{Flywheel Assembly}

The flywheel assembly is designed to simulate vehicle gross weights of 26,000 to $66,000 \mathrm{lb}$. with the maximum being 40,000 $\mathrm{lb}(18,144 \mathrm{~kg})$ at a wheel diameter of $4 \mathrm{ft}(1.22 \mathrm{~m})$, and 66,000 $\mathrm{lb}(30,000 \mathrm{~kg})$ at a wheel diameter of $3.25 \mathrm{ft}(1 \mathrm{~m})$. The flywheel assembly consists of a drive shaft with four drive rotors. Each drive shaft supports eight flywheels of different sizes with bearings resting on the shaft. By selectively engaging the flywheels to the drive rotors, vehicle mass can be simulated in approximately $250 \mathrm{lb}(113 \mathrm{~kg})$ increments. 


\subsection{Eddy Current Power Absorbers}

A Mustang model CC300 air cooled eddy current dynamometer is used as a power absorber to simulate load due to rolling friction of the tires and the aerodynamic drag resistance. The eddy


$(745.7 \mathrm{~kW})$ intermittently during peak operation. Dynamometer load at any speed is controlled by the direct current supplied to the coils and the power absorbed is measured by the torque arm force transducer (load cell). A torque arm is also used in the calibration of the load cell, by knowing the distance the torque arm is from the center of rotation and knowing the weight that is applied at that distance, the torque can be calculated, thus the load cell can be calibrated.

\subsection{AC Drive Motors}

Two $20 \mathrm{hp}$ variable speed motors, one on each side of the vehicle, provide limited motoring effort and help overcome frictional losses in the dynamometer drive train.



Figure 4 Driveline of the Chassis Dynamometer 


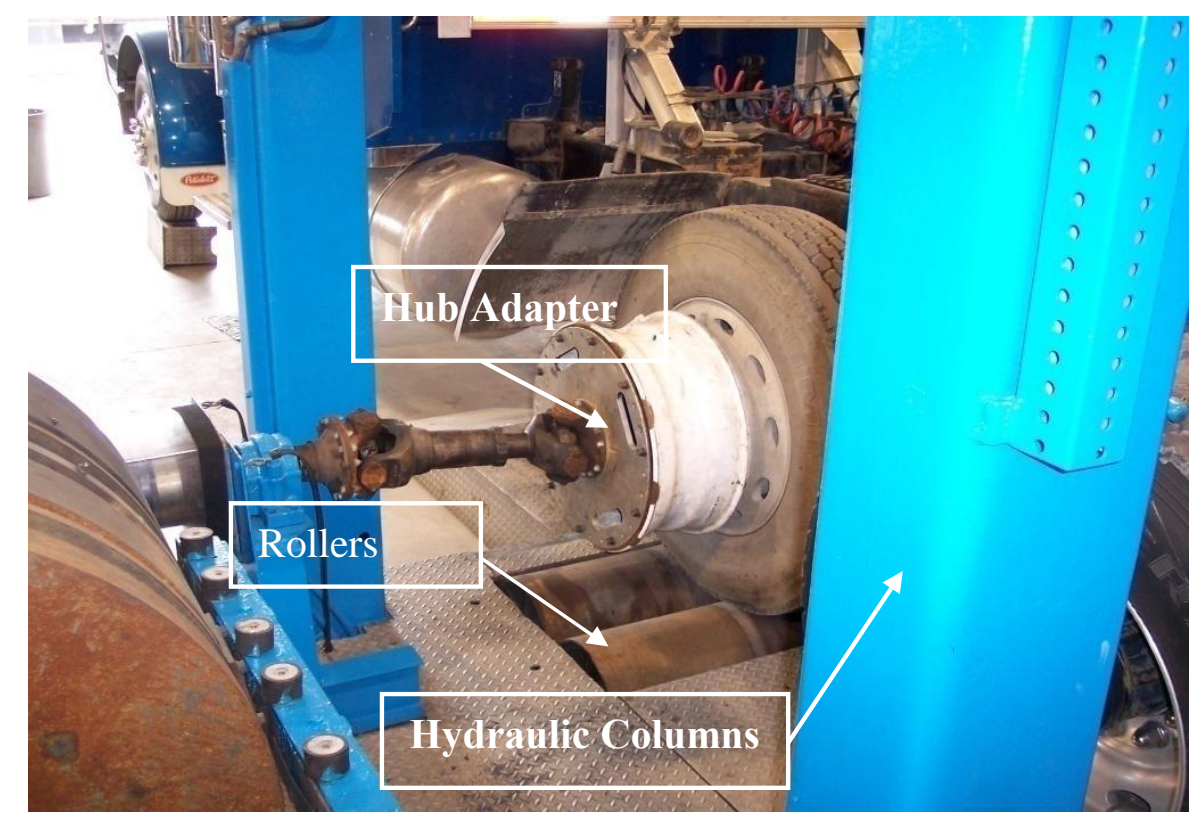

Figure 5 Vehicle Connection and Support of the Chassis Dynamometer

In a chassis dynamometer test the transit torque is controlled by an automated system while the driver is responsible for the control of the vehicle speed. The load supplied by the flywheels simulates the inertial weight on the engine and is controlled by the rotational speed of the vehicle's wheels, while the load due to rolling friction and wind drag is simulated by the eddy current dynamometer. The eddy current dynamometer is controlled by a Dyn-Loc IV control system provided by Dyne-Systems. The Dyn-Loc IV control system was operated by a PID control loop. A PID controller provides a fast and smooth response in controlling the transient set points. During the test, the power absorbers receive the torque set point from the Dyn-Loc IV controller. The set point is equal to the road load power and it is calculated using the following equation

$$
P_{r}=\left(C_{r} M g+\frac{1}{2} \rho_{a} C_{D} A V^{2}\right) V
$$

Where

$\mathrm{P}_{\mathrm{r}}=$ Road load power

$\mathrm{C}_{\mathrm{r}}=$ Coefficient of rolling resistance

$\mathrm{M}=$ Vehicle gravitational mass

$\rho_{\mathrm{a}}=$ Air density 
A $=$ Frontal area of vehicle

$\mathrm{C}_{\mathrm{D}}=$ Coefficient of drag

$\mathrm{V}=$ Vehicle speed

The set point is updated every 100 milliseconds. The speed and torque values are logged at a frequency of $10 \mathrm{~Hz}$ to ensure the test has been performed to the specification.

\subsubsection{Full Flow Dilution Tunnel}

The dilution tunnel, designed and operated according to the regulations specified in CFR 40 Part 86 and Subpart N, was of the critical flow venturi - constant volume sampling (CFV-CVS) type, in which the diluted exhaust was drawn through critical flow venturi using a diesel-powered blower. The dilution tunnel was used to mimic the mixing of exhaust gas with ambient air in the atmosphere and also to cool the exhaust gas sufficiently to reduce the dew point and avoid condensation. Condensation of exhaust samples in the tunnel leads to artifacts in reported emissions and absorption of certain gaseous compounds primarily $\left(\mathrm{NO}_{2}\right)$. Water can also interfere with certain gaseous detection techniques (e.g. NDIR) and will affect formation of particulate matter.

Specifically, the dilution tunnel was 18 inches in diameter, and consisted of three sections: an inlet, a mixing zone, and a sampling zone. The inlet section of the tunnel provided HEPA filtered dilution air at a higher volume flow rate than that metered by the critical flow venturi. This overflow ensured that only filtered air was provided for dilution, and, more importantly, maintained near-ambient tunnel static pressure, which was critical for representative particulate formation. Filtered dilution air was then mixed with exhaust delivered by an insulated transfer tube via an annular configuration, with the raw exhaust at the tunnel centerline. In order to enhance the mixing of the two streams, an orifice plate was sandwiched between the two flanges that joined the tunnel inlet to the main mixing section of the tunnel. The mixing section (a minimum of 10 diameters in length) provided for a fully developed turbulent profile that reduced the sensitivity of sample probe placement. Gaseous and particulate matter samples were collected from sampling probes that were distributed about the centerline of the dilution tunnel's sample zone. Downstream of the sampling zone, a reducing section directed the tunnel flow rate through a 12-inch flexible tube into the critical flow venturi. 


\subsubsection{Critical Flow Venturi}

A critical flow venturi is used to ensure that the mass flow rate is constant at any given upstream pressure and temperature. The CFV-CVS system can operate at nominal flow rates from 1000 to $3000 \mathrm{scfm}$ which can be changed in increments of $500 \mathrm{scfm}$ by threading the correct plug into the throat of the venturi. The change in the venturi throat diameter by the plug changes the flow rate.

At choked conditions, the flow rate through the $\mathrm{CFV}$ is a function of the diameter of the venturi throat and the upstream temperature and pressure. The mass flow rate is then determined using the following equation

$$
\mathrm{Q}=\frac{\mathrm{K}_{\mathrm{v}} \mathrm{P}}{\sqrt{\mathrm{T}}}
$$

Equation 2

Where

$\mathrm{Q}=$ the flow rate in scfm at standard conditions $\left(20^{\circ} \mathrm{C}\right.$ and $\left.101.3 \mathrm{kPa}\right)$

$\mathrm{K}_{\mathrm{v}}=$ the discharge coefficient of the venturi

$\mathrm{P} \quad=\quad$ the absolute pressure at the inlet of the venturi in $\mathrm{kPa}$

$\mathrm{T}=$ the absolute temperature at the inlet of the venturi in $\mathrm{K}$

The calibration of the venturi using an accurate flowmeter and a restrictor valve traceable to National Institute of Standards and Technology (NIST) standards is discussed in detail in the next chapter.

\subsubsection{Secondary Dilution Tunnel and Particulate Sampling}

PM sampling was completed in accordance with CFR 40 Part 86 subpart $\mathrm{N}$ which utilizes a double dilution method. This method essentially involves drawing the diluted exhaust from the full flow dilution tunnel into the secondary dilution tunnel at the sampling zone. The sample in the secondary dilution tunnel can be further diluted by additional air in order to keep the filter face temperature below $125^{\circ} \mathrm{F}$, although secondary stage dilution was not necessary for this study. The diluted exhaust from the secondary tunnel is passed through two fluorocarbon coated 
glass fiber filters (T60A20), housed in a stainless steel filter holder, to collect PM, which consists of elemental carbon, soluble organic fraction, sulfates and bound water. The T60A20 filters used for collecting PM exhibited 99.95\% collection efficiency following ASTM D 2986-95A 0.3 $\mu \mathrm{m}$ (DOP) at $32 \mathrm{~L} / \mathrm{min} / 100 \mathrm{~cm} 2$ filter media

The exhaust is drawn into the secondary dilution tunnel by a $1 \frac{1}{2}$ " diameter tube from the primary dilution tunnel sampling zone. The sample then enters the secondary dilution tunnel which is 30" long and 3" in diameter this creates a large volume for the sample to mix with secondary dilution air (if necessary) and lower the temperature to $125^{\circ} \mathrm{F}$. The flow into the dilution tunnel is controlled by two rotary vane pumps and two mass flow controllers, one each for the total secondary tunnel flow and secondary dilution air flow. The mass flow controller is recalibrated periodically using a laminar flow element.

\subsubsection{Gaseous Emissions Sampling System}

Mass emissions rates of the exhaust gases were determined by measuring the concentration and the total flow. The gaseous emissions sampling system consisted of heated probes with "tip span" feature, heated sample lines and gas analyzer bench built in accordance to CFR 40 Part 86 subpart $\mathrm{N}$ regulations. The samples were drawn 10-diameters downstream of the mixing zone in order to ensure thorough mixing of the exhaust with dilution air and a fully developed turbulent flow. A blunt turbulent profile reduces radial variation in sample concentration. The exhaust emissions were sampled by gas analyzers via heated lines and the flow to the analyzers were controlled by flow meters and differential pressure regulators. Three separate heated probes and sample lines were used to sample $\mathrm{THC}, \mathrm{NO}_{\mathrm{X}}$, and $\mathrm{CO} / \mathrm{CO}_{2}$. The temperature of the probes and the sample lines were controlled and maintained by a temperature control module (TCM). The sample lines were chosen depending on the gas to be analyzed by the analyzer, Teflon coated lines were used for sampling $\mathrm{CO}, \mathrm{CO}_{2}$ and $\mathrm{NO}_{\mathrm{x}}$ while a stainless steel heated line was used for analyzing THC as the line was maintained at a higher temperature. 


\subsubsection{Emissions Sampling System}

All gaseous emissions analyzers and dynamometer control and signal conditioning equipment were housed in the analytical trailer. The gas analyzers used heated lines to sample from the dilution tunnel. The regulated emissions bench consisted of $\mathrm{CO}_{2}$ analyzer, $\mathrm{CO}$ analyzer, $\mathrm{NO}_{\mathrm{x}}$ analyzer and THC analyzer. The operating principle and the sample condition required for these analyzers are explained in the following sections.

\subsubsection{Oxides of Nitrogen $\left(\mathrm{NO}_{\mathrm{x}}\right)$ Analyzer}

The regulated emissions bench consisted of two California Analytical Instruments 200 CLD $\mathrm{NO}_{\mathrm{x}}$ analyzers, one for analyzing $\mathrm{NO}$ and the other for analyzing $\mathrm{NO}_{\mathrm{x}}$. Both $\mathrm{NO}$ and $\mathrm{NO}_{\mathrm{x}}$ samples were sampled from same heated probe and sampling line, which were maintained at a temperature of $240{ }^{\circ} \mathrm{F}\left(115.5^{\circ} \mathrm{C}\right)$ during the test. The sample line was maintained at a high temperature in order to prevent condensation of water, thereby reducing losses of water soluble $\mathrm{NO}_{2}$.

The analyzer uses a heated chemiluminescent measurement principles to determine $\mathrm{NO}$ and $\mathrm{NO}_{\mathrm{x}}$. For NO determination the sample is quantitatively converted into $\mathrm{NO}_{2}$ by gas-phase oxidation with molecular ozone. As a result of this reaction, approximately $10 \%$ of the $\mathrm{NO}_{2}$ molecules are raised to an electronically excited state, followed by immediate reversion to the non-excited state accompanied by emissions of photons. The photons emitted impinge on a photo-multiplier detector generating a low-level DC current proportional to the amount of NO present in the sample. The $\mathrm{NO}_{\mathrm{x}}$ analyzer operates on the same principle as the $\mathrm{NO}$ analyzer, except the sample is passed through a converter where $\mathrm{NO}_{2}$ is converted into $\mathrm{NO}$ before entering into the reaction chamber. Thus the analyzer response will be proportional to the NO present in the original sample plus the $\mathrm{NO}$ produced by dissociation of $\mathrm{NO}_{2}$.

\subsubsection{Carbon Monoxide (CO)/Carbon Dioxide $\left(\mathrm{CO}_{2}\right)$ Analyzer}

Even though $\mathrm{CO}_{2}$ emissions are not regulated, it was measured continuously in order to determine dilution factor in the tunnel and to calculate fuel consumption of the vehicle being 
tested. The $\mathrm{CO}$ and $\mathrm{CO}_{2}$ in the sample were analyzed using a Horiba Model AIA-210 a nondispersive infrared analyzer. Both carbon monoxide and carbon dioxide were sampled from the same heated probe and heated sample line. The sample line was maintained at a temperature of $240{ }^{\circ} \mathrm{F}\left(115.5^{\circ} \mathrm{C}\right)$ in order to avoid water condensation in the sample line, thereby preventing water soluble compounds in the exhaust from dissolving in condensed water. The sample was passed through heated filter element in order to prevent particulate matter entering into the analyzer. The sample was then passed through a refrigerator/dryer system before entering into the analyzer to remove any traces of water in the sample as NDIR is sensitive to moisture in the sample.

NDIR analyzers work on the principle of selective absorption of infrared energy. The analyzer consists of two cells, a flow through sample cell and a sealed reference cell, through which two equal energy infrared beams are passed. The difference between the infrared energy absorbed by the two cells is continuously measured, using solid state electronics, and it is proportional to the amount of $\mathrm{CO} / \mathrm{CO}_{2}$ present in the sample. There are two $\mathrm{CO}$ analyzers in the bench, one for low $\mathrm{CO}$ which had an operating range from $0-100 \mathrm{ppm}$ and $0-2500 \mathrm{ppm}$ and the other one for high $\mathrm{CO}$ which had an operating range of 0-1000ppm and 0-5000ppm. The $\mathrm{CO}_{2}$ analyzer had an operating range of $0-2 \%$ and $0-6 \%$.

\subsubsection{Total Hydrocarbon (THC) Analyzer}

A Rosemount Model 402 hydrocarbon analyzer working on the principle of heated flame ionization detector (HFID) was used to analyze Total Hydrocarbons (THC). The HC sampling system included a heated probe with heated sampling line maintained at a temperature of $375^{\circ} \mathrm{F}$ $\left(190.5^{\circ} \mathrm{C}\right)$ in order to prevent heavier hydrocarbons from condensing, and reducing error in the HC measurement. The analyzer has an operating range from 5-2,500 ppm carbon.

The hydrocarbon analyzer consists of a burner which works as a sensor through which a regulated flow of sample gas is passed. The flame in the burner is sustained by regulated flows of fuel gas and air (40\% hydrogen and $60 \%$ helium). The exact ratio of hydrogen to helium was 
accounted for through the FID peaking process which is covered in detail in the analyzer calibration section [14]. The hydrocarbon passing through the flame undergoes a complex ionization process that produces electrons and positive ions. Polarized electrodes collect these ions, causing current to flow through an electronic measuring circuit. The ionization current generated is proportional to the rate at which carbon atoms enter the burner, and hence a measure of the concentration of the hydrocarbons in the original sample.

\subsubsection{Gravimetric PM Media Conditioning and Weighing}

The media used in collecting PM for gravimetric analysis were conditioned and pre-weighed in the class 1000 clean-room, located at the WVU Engine and Emissions Research Laboratory (EERL) before transporting them to the test site. The filters were conditioned in an environmentally controlled chamber maintained at $70{ }^{\circ} \mathrm{F}$ with a relative humidity of $50 \%$, for at least one hour before being weighed according to CFR 40 part 86 subpart $\mathrm{N}$ specifications. The $70 \mathrm{~mm}$ filters were placed in glass petri dishes, with their lids closed but not sealed in order to prevent dust from accumulating on the media while allowing for humidity exchange. Two reference filters were conditioned with the test filters and placed in the environmental chamber in order to account for change in the filter weight due to fluctuation in humidity. The reference filters were weighed before and after any set of media were weighed to ensure that the conditions in the environmental chamber were stable.

The filters were pre-weighed after a stabilization period of 24 hours using a Sartorious microbalance. The balance was interfaced with a computer in which the filter weights were logged for future reference and use. The filters were conditioned for several hours in the chamber before the petri dishes were sealed and packed in padded envelopes for shipping to the test site.

The petri dishes containing the filter media were sealed and placed in padded envelopes after they had been pre-weighed. The set of envelopes containing media required for one test were placed together to aid in quick loading of the media into the sampling system. The sealed media were transported overnight to the test site. After the media was received at the test site it was placed in the conditioning room until used. A media tracking application was developed to identify the media with the test sequence and run number. The tracking tool also aided in QA/QC 
protocol. The used media were placed back into their respective petri dishes in the conditioning room and were tracked before shipping to the location, where they were analyzed.

The media required for particulate matter emissions were removed from their storage location and loaded into their sampling device. The media loading was done in a controlled environment when the exhaust was ready to be sampled. Before loading the media, barcodes were logged into a used media database with respect to the test sequence and run number so that the sample collected on the media can now be associated with a particular test. A set of media were used as field blank to study the effect of transportation and conditioning at the test site on the filter mass.

\subsubsection{Chassis Dynamometer Emissions Testing Procedure}

\subsubsection{Initial Test Set-up}

Before mounting the vehicle on the chassis dynamometer the appropriate flywheel combination was determined and locked in place to simulate the inertial load of the vehicle. For the vehicle chassis portion of the program, information was gathered from MDT employees indicating that both 04208 and 05108 had a total passenger capacity (seated/standing) of approximately 88, including driver. Considering that 04208(DDC S50) had 39 seats and 05108(Cummins ISM) had 38 seats, this suggested standing room of 49 and 50, respectively. However, this passenger payload, at an average passenger weight of $150 \mathrm{lbs}$., would have made the test weight in excess of both vehicles' gross vehicle weight ratings (GVWR). As a result, the available vehicle payload, which is the difference of the GVWR and measured curb weight, was calculated, and half this value was added to the measured curb weight in order to arrive at the test weight. For the chassis dynamometer testing, discrete test weight intervals were available, so the closest value was used, that being $35,700 \mathrm{lbs}$. The chassis test weight summary for both vehicles is included in Table 1. Theoretical coast down characteristics were then calculated based upon this weight, number and size of tires, and vehicle frontal area. The outer rear wheel on the drive axle was removed and fitted with hub adapters which are later connected to the face plate. The vehicle was backed onto the dynamometer and the vehicle drive axle which drives the flywheel assembly and power absorbers was connected through a hub adapter. The vehicle was leveled with the drive axle and the tires were checked for any distortion as it would add to the vehicle 
loading. The vehicle exhaust was then connected to the dilution tunnel via insulated transfer tube. The vehicle was chained down to the dynamometer bed as a safety measure.

Table 1 Vehicle Test Weight Information

\begin{tabular}{|c|c|c|}
\hline MDT Bus Number & $\begin{array}{l}\text { DDC S50 } \\
(04208)\end{array}$ & $\begin{array}{c}\text { Cummins ISM } \\
(05108)\end{array}$ \\
\hline Vehicle Gross Vehicle Weight Rating (GVWR) & $42,540 \mathrm{lbs}$ & $42,550 \mathrm{lbs}$. \\
\hline Measured Scale Weight No Passengers (Curb Weight) & $29,840 \mathrm{lbs}$. & $29,600 \mathrm{lbs}$. \\
\hline Available Payload (GVWR - Curb Weight) & 12,700 lbs. & 12,950 lbs. \\
\hline Indicated Passenger Capacity (Seated and Standing) & 88 (87 + driver) & 88 (87+ driver) \\
\hline Average Passenger Weight & $150 \mathrm{lbs}$. & $150 \mathrm{lbs}$. \\
\hline Fully Loaded Indicated Passenger Payload & 13,200 lbs. & $13,200 \mathrm{lbs}$. \\
\hline Fully Loaded Indicated Weight & 43,040 lbs. $*$ & 42,800 lbs. ${ }^{*}$ \\
\hline $\begin{array}{l}\text { Calculated Half Available Payload (GVWR +1/2* Available } \\
\text { Payload) }\end{array}$ & 36,190 lbs. & 36,075 lbs. \\
\hline $\begin{array}{l}\text { Test Weight (Limited to Chassis Test Weight } \\
\text { Discretization) }\end{array}$ & $35,700 \mathrm{lbs}$. & $35,700 \mathrm{lbs}$. \\
\hline
\end{tabular}

Prior to testing, a background test was conducted to assess the contribution of ambient particulate matter. These data were averaged with a similar test performed at the conclusion of each day of testing. The vehicle was then operated at a high speed to warm the lubricating oil in the differentials. This was done to reduce additional load on the vehicle due to cold, highly viscous oil. During differential warm-up, the gas analyzers were zero-spanned with the blower operating normally. The driver interface speed monitor and communication head sets were implemented to aid the driver in following the scheduled drive cycle. A warm-up test was conducted, which involved operating the vehicle through the scheduled drive cycle with dummy media loaded, in order to verify gaseous calibration ranges and mass flow controller set points. After the warm-up run, the vehicle was shut down and allowed to soak for twenty minutes. During the soak time, the official media required for various sampling were loaded in their respective holders and mounted onto the tunnel. A set of field blanks were maintained to study the effect of transportation on the used and unused media (see $\$ 3.3 .7$ ). The bags used to sample the dilution air and the exhaust continuously were evacuated before the test using pumps and vacuum gauge to indicate when the bags were fully evacuated. 
The driving schedule used for this test was the WVU MDT bus cycle. A warm-up MDT cycle was performed which warmed the engine, and the vehicle was left for a 20 minute soak period before the actual testing began. Temperature, pressure, humidity and the flow data were continuously recorded at a frequency of $10 \mathrm{~Hz}$ on the data logging computer. The speed of the vehicle was controlled by the driver according to the driving schedule displayed on the monitor placed in the vehicle. The torque set point for the power absorber was controlled by the host computer. If there was any failure in the dynamometer or data acquisition, or any discrepancy in the followed driving schedule, the driver was alerted by the communication head set and the test was repeated.

After the completion of a test cycle, the vehicle was shut down and allowed to soak for twenty minutes, allowing the vehicle to return to its rested state to eliminate test-to-test variability. During the soak time, one of the field engineers was responsible for initial data quality confirmation. If there were any problems, corrective action was taken before repeating the next set of test cycles. All the data required for emissions calculation were stored in the data logging computer. These data were reduced by a post processing program to give the emissions results in grams/mile units.

\subsubsection{Analyzer Calibration}

The calibration of the analyzers was performed in accordance with the regulations stated in CFR 40, Part 86, and Subpart N. All the analyzers were calibrated to the range of emissions level that was observed in the vehicle being tested. The span gases used to calibrate the analyzers had an accuracy of $1 \%$ traceable to NIST, whereas the zero reference was attained by using the zero air generated at the site. The flame in the HFID analyzer used for HC analysis was fueled by a mixture of $40 \%$ hydrogen and $60 \%$ helium. Once the analyzers were stabilized, the temperature of the sampling lines were verified and a 11 point calibration was performed. A gas divider, which works on the effect of capillary flow, was used to obtain 11 equally spaced concentration levels by mixing the span gas and the zero air. The analyzers were allowed to stabilize at each calibration point and a computer averaged reading of that value was recorded. After the calibration, the data points corresponding to the gas concentration were fitted to a polynomial curve which was used in converting the ADC codes to engineering units. The analyzers were 
checked for zero and span values before and after each test and the drift value was found to be more than $3 \%$ for $\mathrm{THC}, 2 \%$ for $\mathrm{CO} / \mathrm{CO}_{2}$ and $\mathrm{NO}_{\mathrm{x}}$ they were recalibrated and the test was repeated. The analyzers were recalibrated with different span gas concentration if the emissions were out of its range of measurement. The calibration was performed frequently and these calibration files were overwritten by the new calibration points in order to prevent the use of wrong calibration files.

A 'HFID burner peaking test' is an analyzer check that was performed on the THC analyzer to optimize the HFID response by accounting for differences in the ratio of hydrogen to helium[14]. In this process, the analyzer response was measured for $100 \%$ span gas and zero air for different combination of HFID burner fuel and air pressures. The setting at which the analyzer gave the highest response was selected and used. An 'HC hang-up' check was also performed on the HFID analyzer. The sampling probes were back flushed and steps were taken to rectify if the difference in the response was more than $2 \%$.

An oxygen interference test, prescribed in 40 CFR, Part 86, Subpart N, was also performed on the HFID. This check was conducted to verify analyzer sensitivity to changes in sample $\mathrm{O}_{2}$ concentration.

$\mathrm{NO}_{\mathrm{x}}$ efficiency test, which is a check of the $\mathrm{NO}_{\mathrm{x}}$ analyzer, in order to determine the converter efficiency in converting $\mathrm{NO}$ to $\mathrm{NO}_{2}$. If the conversion efficiency turned out to be less than $90 \%$ then maintenance was performed to rectify the situation.

Water interference check was performed on NDIR analyzers used for analyzing $\mathrm{CO} / \mathrm{CO}_{2}$ as moisture could affect the response of these analyzers. The test was performed by supplying the span gas bubbled through water to the analyzer via dryer/chiller.

\subsubsection{Mass Flow Controller Calibration}

Mass flow controllers were used in controlling the flow rate of TPM flow across a sample media filter and various other unregulated emissions sampling systems. Manufacturer-supplied calibration curves were verified against a Meriam laminar flow element (LFE). Meriam provides 
a calibration equation and coefficients for each LFE which is obtained through calibration involving a flow meter that is traceable to NIST standards. A five point calibration curve was fit across the MFC full operating range. The flow through the LFE was calculated using the following equation [15].

$$
\dot{\mathrm{V}}_{\text {actual }}=[\mathrm{B} \times(\Delta \mathrm{P})+\mathrm{C} \times(\Delta \mathrm{P})] \times \frac{\mu_{\text {std }}}{\mu_{\text {flow }}}
$$

Equation 3

Where

$B$ \& $C=$ LFE specific coefficients

$\Delta \mathrm{P}=$ Pressure differential measured across LFE

$\frac{\mu_{\text {std }}}{\mu_{\text {flow }}}=$ Viscosity correction factor

The viscosity variations were calculated using the correction factor given in the following equations

$$
\begin{gathered}
\text { Correctionfactor }=\left(\frac{529.67}{459.67+T\left({ }^{o} F\right)}\right) \times\left(\frac{181.87}{\mu_{g}}\right) \\
\mu_{g}=\frac{14.58+\left(\frac{459.67+T\left({ }^{o} F\right)}{1.8}\right)}{110.4+\left(\frac{459.67+T\left(^{o} F\right)}{1.8}\right)}
\end{gathered}
$$

Equation 4

Equation 5

Differential pressure across the LFE and absolute pressure was measured using a Heise ${ }^{\circledR}$ pressure reader and the temperature was measured using a Fluke Temperature calibrator. The actual flow rate measured through the LFE was converted to standard flow rate by CFR 40 part 86 subpart $\mathrm{N}$ specified standard condition of $20^{\circ} \mathrm{C}$ and $101.1 \mathrm{kPa}$. 


\subsubsection{CFV-CVS Calibration}

The Critical Flow Venturi used in the Constant Volume Sampling system was calibrated before arriving at the test site using subsonic flowmeter and an accurate flow restrictor as specified in CFR 40 part 86 subpart $\mathrm{N}$. The calibration of the CFV is based on the following flow equation for a critical venturi where gas flow is a function of inlet temperature and pressure. The calibration of the CFV was not preformed on site but it was verified which is explained in the flowing section.

$$
\mathrm{Q}_{\mathrm{s}}=\frac{\mathrm{K}_{\mathrm{V}} \mathrm{P}}{\sqrt{\mathrm{T}}}
$$

\section{Equation 6}

Where

$\mathrm{Q}_{\mathrm{S}}=$ Flow rate in $\mathrm{cfm}$

$\mathrm{P}=$ Absolute inlet pressure, $\mathrm{kPa}$

$\mathrm{T}=$ Absolute inlet temperature, $\mathrm{K}$

$\mathrm{K}_{\mathrm{v}}=$ Calibration coefficient

The calibration set-up was leak checked before taking the readings, initially the blower was started with flow restrictor completely open. The pressure reading was recorded after the system was stabilized. The flow restriction was varied to obtain eight readings in the critical flow range of the venturi. The air flow rate $Q_{S}$ at each data point is calculated in standard cubic feet per minute and calibration coefficient is calculated using the following equation

$$
\mathrm{K}_{\mathrm{V}}=\frac{\mathrm{Q}_{\mathrm{s}} \sqrt{\mathrm{T}_{\mathrm{V}}}}{\mathrm{P}_{\mathrm{V}}}
$$

Equation 7

Where

$\mathrm{Q}_{\mathrm{S}}=$ Flow rate is standard cubic feet per minute at standard conditions $20{ }^{\circ} \mathrm{C}$ and $101.1 \mathrm{kPa}$ $\mathrm{T}_{\mathrm{V}}=$ Venturi inlet temperature, $\mathrm{K}$

$\mathrm{P}_{\mathrm{V}}=$ Venturi Inlet Pressure, $\mathrm{kPa}$ 
During choked flow conditions, $\mathrm{K}_{\mathrm{V}}$ will have a relatively constant value. As the pressure decreases, the flow becomes subsonic, and the value of $\mathrm{K}_{\mathrm{V}}$ decreases drastically. The calibration coefficient was determined for a minimum of 8 points in the choked region, and, from these data, the average calibration coefficient and standard deviation was calculated.

\subsubsection{CFV-CVS Calibration Verification}

The CVS system was verified by injecting a known quantity of propane into the primary dilution tunnel while the CFV-CVS system was operated. The concentration of the recovered propane was determined using a pre-calibrated HFID analyzer and the mass of propane injected was measured by the flow data and the density of propane. The propane injection test helped in determining leaks in the tunnel and any discrepancy in the flow measuring device (CFV-CVS system). CFR 40 part 86 subpart $\mathrm{N}$ proposes a gravimetric method while Horiba describes a critical orifice method in performing the propane injection test.

The methodology recommended by Horiba was used for this program. This verification utilizes a propane injection kit with a critical flow orifice meter to accurately measure the amount of propane injected into the tunnel. The flow rate of propane through the orifice meter is determined by measuring the inlet temperature and pressure using the following equation. The recovered propane at the sample zone was then measured and using Equation $9 \& 3-14$ the volume of the recovered propane was calculated.

$$
\mathrm{q}=\frac{\mathrm{A}+(\mathrm{B} \times \mathrm{P})+\left(\mathrm{C} \times \mathrm{P}^{2}\right)}{\sqrt{460+\mathrm{T}}}
$$

Equation 8

Where

$\mathrm{q}=$ flow rate through orifice in $\mathrm{scfm}$ at standard condition $\left(20{ }^{\circ} \mathrm{C}\right.$ and $\left.101.1 \mathrm{kPa}\right)$

$\mathrm{A}, \mathrm{B}$ and $\mathrm{C}=$ calibration coefficients provided by the orifice manufacturer

$\mathrm{P}=$ absolute orifice inlet pressure, in psia (gauge pressure + atmospheric pressure)

$\mathrm{T}=$ orifice inlet temperature in ${ }^{\circ} \mathrm{F}$

For this program, if the error was greater than $\pm 2 \%$, then the cause for discrepancy was identified and corrected. 


\subsubsection{Emissions Calculations}

The continuous voltage signal transmitted by the gas analyzers during the test were converted to ADC codes by an analog to digital converter before storing in the computer. The ADC codes were converted to ppm concentration values using the calibration equations from each analyzer by a post processing program. The concentration, in ppm, together with the total volume of dilution tunnel, dilution factor and background concentration level was used in calculating the distance specific emissions rates [14].

The total volume of the dilute exhaust drawn through the tunnel over a period of time was given by the following equation. This equation was used in calculation of regulated and unregulated emissions in distance specific units.

$$
\mathrm{V}_{\text {mix }}=\sum_{\mathrm{i}=1}^{\mathrm{n}}\left(\mathrm{V}_{(\text {mix }) \mathrm{i}} \times \Delta \mathrm{t}\right)
$$

Equation 9

Where

$\mathrm{V}_{(\text {mix)i }}=$ Instantaneous dilute exhaust gas mixture flow rate $\left(\mathrm{ft}^{3} / \mathrm{sec}\right)$, was given by the following equation

$$
\mathrm{V}_{(\text {mix }) \mathrm{i}}=\frac{\mathrm{K}_{\mathrm{V}} \times \mathrm{P}_{\mathrm{Vi}}}{\sqrt{\mathrm{T}_{\mathrm{Vi}}}}
$$

Equation 10

$\Delta \mathrm{t}=$ Time interval between instantaneous measurement points (seconds)

$\mathrm{n}=$ number of instantaneous points taken during the test

$\mathrm{K}_{\mathrm{v}}=$ Calibration constant for Critical Flow Venturi corrected to standard conditions during calibration

$\mathrm{P}_{\mathrm{vi}}=$ Instantaneous absolute pressure at venturi inlet (in. $\mathrm{Hg}$ )

$\mathrm{T}_{\mathrm{vi}}=$ Instantaneous temperature at the venturi inlet $(\mathrm{R})$

Dilution Factor is a ratio of the theoretical amount of carbon dioxide in the raw exhaust due to stoichiometric combustion to the summation of actual measured concentration of $\mathrm{CO}, \mathrm{CO}_{2}$ and 
the individual components of the organic matter. The composition of the fuel used is given by $\mathrm{C}_{\mathrm{x}} \mathrm{H}_{\mathrm{y}} \mathrm{O}_{\mathrm{z}}$ as a measurement for the fuel used.

$$
\mathrm{DF}=\frac{100 \times\left(\frac{\mathrm{x}}{\mathrm{x}+\mathrm{y} / 2+3.76 \times \mathrm{x}+\mathrm{y} / 4-\mathrm{z} / 2}\right)}{\mathrm{CO}_{2 \mathrm{e}}+\mathrm{CO}_{\mathrm{e}}+\sum \mathrm{OM}_{\mathrm{e}} \times 10^{-4}}
$$

\section{Equation 11}

Where

$\mathrm{CO}_{2 \mathrm{e}}=$ Carbon dioxide concentration of the dilute exhaust sample corrected for background, in ppm.

$\mathrm{CO}_{\mathrm{e}}=$ Carbon monoxide concentration of the dilute exhaust sample corrected for background, in ppm.

$\Sigma \mathrm{OM}_{\mathrm{e}}=$ Summation of the individual components of the organic matter such as $\mathrm{HC}_{\mathrm{e}}, \mathrm{CH}_{3} \mathrm{OH}_{\mathrm{e}}$ etc in ppm carbon equivalent.

The numerator is the concentration of the $\mathrm{CO}_{2}$ present in the stoichiometrically combusted air/fuel mixture which is determined by the following equation

$$
\mathrm{C}_{\mathrm{x}} \mathrm{H}_{\mathrm{y}} \mathrm{O}_{\mathrm{z}}+\mathrm{k}\left(\mathrm{O}_{2}+3.76 \mathrm{~N}_{2}\right) \rightarrow \mathrm{aCO}_{2}+\mathrm{bH}_{2} \mathrm{O}+3.76 \mathrm{cN}_{2}
$$

\section{Equation 12}

The constants $\mathrm{a}, \mathrm{b}, \mathrm{c}$ is obtained by solving the following equations

$\mathrm{C}: \quad \mathrm{x}=\mathrm{a}$

$\mathrm{H}: \quad \mathrm{y}=2 \mathrm{~b}$

$\mathrm{O}: \quad \mathrm{z}+2 \mathrm{k}=2 \mathrm{a}+\mathrm{b}$

$\mathrm{N}_{2}: \quad \mathrm{k}=\mathrm{c}$

This gives the following result

$\mathrm{a}=\mathrm{x}$

$\mathrm{b}=\mathrm{y} / 2$

$c=x+y / 4-z / 2$ 


\subsubsection{Equations to Calculate Distance Specific Mass of Regulated Emissions}

The distance specific mass of the regulated emissions, is defined as the ratio of the mass of an exhaust constituent to the distance traveled by the vehicle. Equations governing the calculation of mass of each exhaust constituent are given below [14].

The mass of carbon monoxide is determined by the following equation

$$
\dot{\mathrm{C}} \mathrm{O}_{\text {mass }}=\sum_{\mathrm{i}=1}^{\mathrm{n}}\left[\frac{\left.(\mathrm{CO})_{\mathrm{e}}\right)_{\mathrm{i}}}{1 \times 10^{6}} \times \mathrm{V}_{(\text {mix }) \mathrm{i}} \times \rho_{\mathrm{CO}} \times \Delta \mathrm{t}\right]-\frac{\mathrm{CO}_{\mathrm{d}}}{1 \times 10^{6}} \times\left(1-\frac{1}{\mathrm{DF}}\right) \times \mathrm{V}_{\text {mix }} \times \rho_{\mathrm{CO}}
$$

Equation 13

Where

$\left(\mathrm{CO}_{\mathrm{e}}\right)_{\mathrm{i}}=$ Instantaneous carbon monoxide concentration of the dilute exhaust sample taken from the $\mathrm{CO}$ analyzer, in ppm.

$\mathrm{V}_{(\mathrm{mix}) \mathrm{i}}=$ Instantaneous dilute exhaust gas mixture flow rate, in scfm.

$\rho_{\mathrm{co}}=$ Density of carbon monoxide which is $32.97 \mathrm{~g} / \mathrm{ft}^{3}$ at STP.

$\Delta \mathrm{t}=$ Time difference between two instantaneous measurement points, in sec.

$\mathrm{CO}_{\mathrm{d}}=$ Concentration of carbon monoxide in the dilution air corrected for water vapor, in ppm.

$$
\mathrm{CO}_{\mathrm{d}}=(1-0.000323 * \mathrm{R}) * \mathrm{CO}_{\mathrm{dm}}
$$

Equation 14

$\mathrm{R}=$ Relative humidity .

$\mathrm{CO}_{\mathrm{dm}}=$ Concentration of carbon monoxide of the dilution air as measured, in ppm.

$\mathrm{V}_{\text {mix }}=$ Total volume of dilute exhaust gas mixture for the entire test, in $\mathrm{ft}^{3}$.

The mass of Carbon dioxide is determined by the following equation

$$
\dot{\mathrm{C}} \mathrm{O}_{2 \text { mass }}=\sum_{\mathrm{i}=1}^{\mathrm{n}}\left[\frac{\left(\mathrm{CO}_{2 \mathrm{e}}\right)_{\mathrm{i}}}{1 \times 10^{6}} \times \mathrm{V}_{(\text {mix }) \mathrm{i}} \times \rho_{\mathrm{CO}_{2}} \times \Delta \mathrm{t}\right]-\frac{\mathrm{CO}_{2 \mathrm{~d}}}{1 \times 10^{6}} \times\left(1-\frac{1}{\mathrm{DF}}\right) \times \mathrm{V}_{\text {mix }} \times \rho_{\mathrm{CO}_{2}}
$$

Equation 15 
Where

$\left(\mathrm{CO}_{2 \mathrm{e}}\right)_{\mathrm{i}}=$ Instantaneous carbon dioxide concentration of the dilute exhaust sample taken from the $\mathrm{CO}_{2}$ analyzer, in ppm.

$\mathrm{V}_{(\mathrm{mix}) \mathrm{i}}=$ Instantaneous dilute exhaust gas mixture flow rate, in scfm.

$\rho_{\mathrm{co} 2}=$ Density of carbon dioxide which is $51.81 \mathrm{~g} / \mathrm{ft}^{3}$ at STP.

$\Delta \mathrm{t}=$ Time difference between two instantaneous measurement points, in sec.

$\mathrm{CO}_{2 \mathrm{~d}}=$ Concentration of carbon dioxide in the dilution air corrected for water vapor, in ppm

$$
C O_{2 d}=(1-0.000323 * R) * C O_{2 d m}
$$

Equation 16

$\mathrm{R}=$ Relative humidity

$\mathrm{CO}_{2 \mathrm{dm}}=$ Concentration of carbon monoxide of the dilution air as measured, in ppm.

$\mathrm{V}_{\text {mix }}=$ Total volume of dilute exhaust gas mixture for the entire test, in $\mathrm{ft}^{3}$.

The mass of the oxides of nitrogen was calculated by the following equation

$$
\dot{\mathrm{N}} \mathrm{X}_{\text {Xmass }}=\mathrm{K}_{\mathrm{H}} \times \sum_{\mathrm{i}=1}^{\mathrm{n}}\left[\frac{\left(\mathrm{NO}_{\mathrm{Xe}}\right)_{\mathrm{i}}}{1 \times 10^{6}} \times \mathrm{V}_{(\text {mix }) \mathrm{i}} \times \rho_{\mathrm{NO}_{\mathrm{x}}} \times \Delta \mathrm{t}\right]-\frac{\mathrm{NO}_{\mathrm{Xd}}}{1 \times 10^{6}} \times\left(1-\frac{1}{\mathrm{DF}}\right) \times \mathrm{V}_{\text {mix }} \times \rho_{\mathrm{NO}_{\mathrm{X}}}
$$

Equation 17

Where

$\left(\mathrm{NO}_{\mathrm{Xe}}\right)_{\mathrm{i}}=$ Instantaneous oxides of nitrogen concentration of the dilute exhaust sample taken from the $\mathrm{NO}_{\mathrm{X}}$ analyzer, in ppm.

$\mathrm{V}_{(\mathrm{mix}) \mathrm{i}}=$ Instantaneous dilute exhaust gas mixture flow rate, in scfm.

$\rho_{\text {NOx }}=$ Density of oxides of nitrogen which is $54.16 \mathrm{~g} / \mathrm{ft}^{3}$ at STP assuming that they are in the form of $\mathrm{NO}_{2}$.

$\Delta \mathrm{t}=$ Time difference between two instantaneous measurement points, in sec.

$\mathrm{K}_{\mathrm{H}}=$ Humidity correction factor, which is given by

$$
\mathrm{K}_{\mathrm{H}}=\frac{1}{(1-0.0026 \times(\mathrm{H}-75))}
$$

Equation 18 


$$
\mathrm{H}=\frac{\left(43.478 \times \mathrm{R}_{\mathrm{i}} \times \mathrm{P}_{\mathrm{d}}\right)}{\left(\mathrm{P}_{\mathrm{b}}-\frac{\left(\mathrm{P}_{\mathrm{d}} \times \mathrm{R}_{\mathrm{i}}\right)}{100}\right)}
$$

Equation 19

$\mathrm{H}=$ Absolute humidity of the engine intake air in grains of water per pound of dry air.

$\mathrm{R}_{\mathrm{i}}=$ Relative humidity of the engine intake air, in $\%$.

$\mathrm{P}_{\mathrm{d}}=$ Saturated vapor pressure, $\mathrm{mm} \mathrm{Hg}$, at the engine intake air dry bulb temperature

$\mathrm{P}_{\mathrm{b}}=$ Barometric pressure, $\mathrm{mm} \mathrm{Hg}$.

$\mathrm{NO}_{\mathrm{Xd}}=$ Concentration of oxides of nitrogen in the dilution air corrected for water vapor, in ppm.

$$
N O_{x_{d}}=(1-0.000323 * R) * N O_{X d m}
$$

Equation 20

$\mathrm{R}=$ Relative humidity

The mass of hydrocarbons is determined by using the following equation

$$
\mathrm{THC}_{\text {mass }}=\sum_{\mathrm{i}=1}^{\mathrm{n}}\left[\frac{\left(\mathrm{HC}_{\mathrm{e}}\right)_{\mathrm{i}}}{1 \times 10^{6}} \times \mathrm{V}_{(\text {mix }) \mathrm{i}} \times \rho_{\mathrm{HC}} \times \Delta \mathrm{t}\right]-\frac{\mathrm{HC}_{\mathrm{d}}}{1 \times 1 \mathrm{O}^{6}} \times\left(1-\frac{1}{\mathrm{DF}}\right) \times \mathrm{V}_{\text {mix }} \times \rho_{\mathrm{HC}}
$$

Equation 21

Where

$\left(\mathrm{HC}_{\mathrm{e}}\right)_{\mathrm{i}}=$ Instantaneous hydrocarbon concentration of the dilute exhaust sample taken from the $\mathrm{HC}$ analyzer, in ppm.

$\mathrm{V}_{(\text {mix)i }}=$ Instantaneous dilute exhaust gas mixture flow rate, in scfm.

$\rho_{\mathrm{HC}}=$ Density of hydrocarbons for diesel fueled vehicle which is $16.27 \mathrm{~g} / \mathrm{ft}^{3}$ at STP.

$\Delta \mathrm{t}=$ Time difference between two instantaneous measurement points, in sec.

$\mathrm{HC}_{\mathrm{d}}=$ Concentration of hydrocarbons in the dilution air, in ppm.

$$
H C_{d}=(1-0.000323 * R) * H C_{d m}
$$

Equation 22

$\mathrm{R}=$ Relative humidity

The mass of particulate matter collected on the filter in the secondary dilution tunnel provides proportional sampling of the PM emissions. The following equation is used to determine the total amount of PM present in whole diluted exhaust flowing through the primary dilution tunnel. 


$$
\dot{\mathrm{P}}_{\text {mass }}=\left(\mathrm{V}_{\text {mix }}+\mathrm{V}_{\mathrm{sf}}\right) \times\left[\frac{\mathrm{P}_{\mathrm{f}}}{\mathrm{V}_{\mathrm{sf}}}-\left(\frac{\mathrm{P}_{\mathrm{bf}}}{\mathrm{V}_{\mathrm{bf}}} \times\left(1-\frac{1}{\mathrm{DF}}\right)\right)\right]
$$

Equation 23

Where

$\mathrm{P}_{\text {mass }}=$ Uncorrected mass of PM emitted during one complete test, in grams .

$\mathrm{V}_{\text {mix }}=$ Total Volume of diluted exhaust flowing through the primary dilution tunnel corrected for standard conditions, in SCF.

$\mathrm{V}_{\text {sf }}=$ Total Sample dilute exhaust flow through the secondary dilution tunnel corrected for standard conditions, in SCF.

$\mathrm{V}_{\mathrm{bf}}=$ Total Background volume across the background filter, in SCF

$\mathrm{P}_{\mathrm{f}}=$ Actual mass of PM collected on the sample filter, in grams.

$\mathrm{P}_{\mathrm{bf}}=$ Actual mass of PM collected on the background filter, in grams.

\subsection{Mobile Emissions Measurement System (MEMS)}

\subsubsection{Introduction}

West Virginia University’s Mobile Emissions Measurement System (MEMS) was designed, fabricated, evaluated, and used as the primary test device to conduct over 1500 tests on heavyduty vehicles powered by engines manufactured by the six signatories to the 1998 Consent Decrees. This research was the direct result of the Consent Decrees entered into by the US Department of Justice and the six Settling Heavy-duty Diesel Engine (S-HDDE) manufacturers, in 1998. WVU was contracted to manage the in-use emissions measurement component of the manufacturers' responsibilities [16,17].

The MEMS is an integration of a number of subsystems, namely, a flow rate measurement system, an emissions sampling and measurement system, and a data acquisition system. The information from these sub-systems is integrated by an in-house data reduction program, capable of producing mass emissions rates on a brake-specific and distance-specific basis. The following sections of this document are included so that the reader may familiarize themselves with the MEMS and its capabilities. 


\subsubsection{MEMS Flow Measurement}

The MEMS flow measurement utilizes the fundamentals of Bernoulli's theorem of flow over a cross section. This cross section known as an Annubar ${ }^{\mathrm{TM}}$ (see Figure 6) is a diamond shape with holes down the leading and trailing edge (points of the diamond) of the tube. These holes are connected to a Validyne P55D differential pressure transducer. As flow moves across the Annubar ${ }^{\mathrm{TM}}$ high pressure is generated on the upstream side (leading edge) then as the flow moves further downstream it meets up again at a point that is further downstream then the trailing edge of the Annubar ${ }^{\mathrm{TM}}$ thus forming a low pressure zone. This differential pressure can then be used to calculate the velocity of the air based on calibration curves that are specific to each Annubar ${ }^{\mathrm{TM}}$. To calculate the flow other parameters are needed, such as exhaust temperature, exhaust absolute pressure as well as the tube diameter. The equation that was used to calculate flow can be seen in Equation 24. Absolute pressure was measured by an Omega PX $41 \mathrm{~T} 0$ pressure transducer and temperature measurements were made using two K type thermocouples. An enclosure that was insulated and temperature controlled was used to house the transducers for the measurement flow parameters (see Figure 8). 


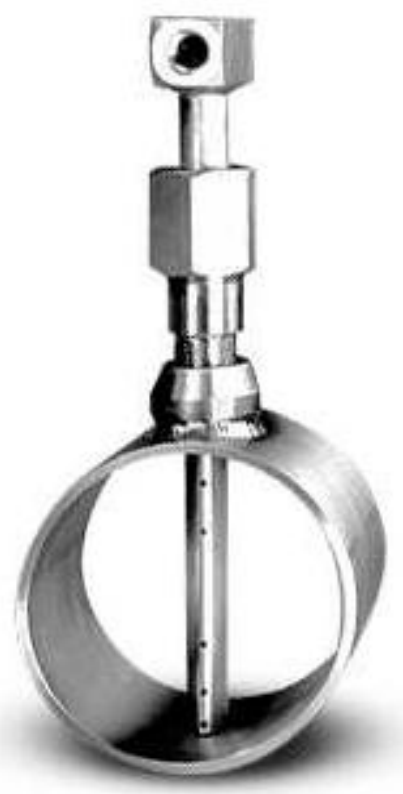

Figure 6 Schematic of the Annubar Flow Rate Measurement Device [24]



Figure 7 Cross Section of Annubar [24] 


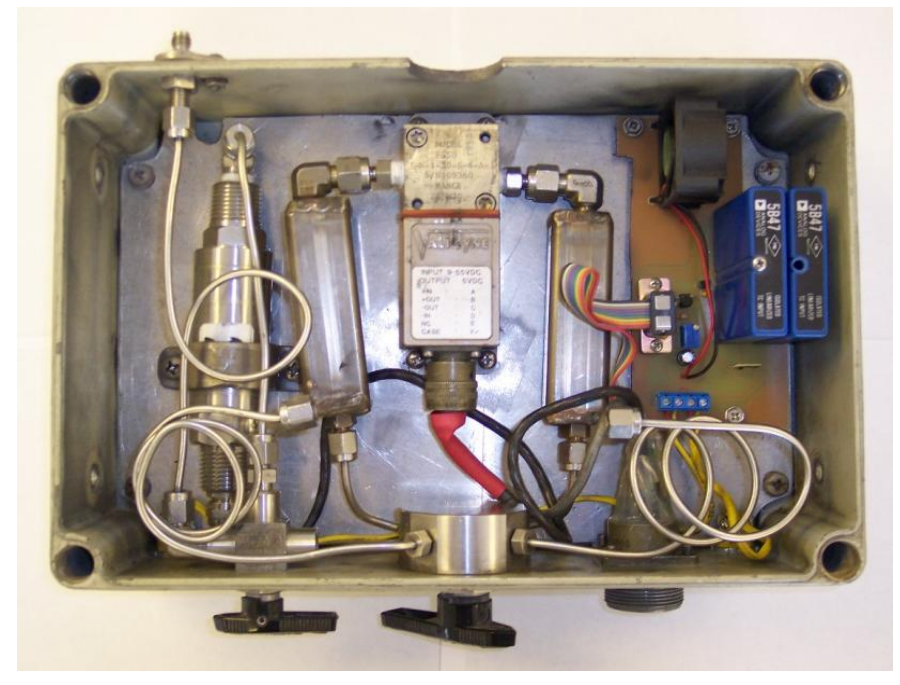

Figure 8 Flow Measurement Transducer Enclosure

$$
Q=F_{N A} \times K \times D^{2} \times F_{R A} \times Y_{A} \times F_{P B} \times F_{T B} \times F_{T F} \times F_{G} \times F_{P V} \times F_{M} \times F_{A A} \times F_{L} \times \sqrt{h_{w}} \times \sqrt{\rho_{F}}
$$

Equation 24

$\mathrm{Q}=$ Volumetric flow rate

$\mathrm{F}_{\mathrm{NA}}=$ Unit conversion factor, 5.6362

$\mathrm{K}=$ Flow rate coefficient, 0.6264

$\mathrm{D}=$ Inner pipe diameter in inches

$\mathrm{F}_{\mathrm{RA}}=$ Reynolds number correction factor, 1

$\mathrm{Y}_{\mathrm{A}}=\mathrm{gas}$ expansion factor, $1-0.00585^{*}\left[\Delta \mathrm{P} /\left(\mathrm{P}_{\mathrm{F}}{ }^{*} \mathrm{k}\right)\right]$

$\Delta \mathrm{P}=$ differential pressure

$\mathrm{P}_{\mathrm{F}}=$ absolute pressure

$\mathrm{k}=$ isentropic gas constant

$\mathrm{F}_{\mathrm{PB}}=$ Pressure based correction factor, 1.0023

$\mathrm{F}_{\mathrm{TB}}=$ Temperature based correction factor, 1.0154

$\mathrm{F}_{\mathrm{TF}}=$ Flowing temperature correction factor, [520/(Temperature Base $\left.\left({ }^{\circ} \mathrm{F}\right)+460\right]$

$\mathrm{F}_{\mathrm{G}}=$ Specific gravity factor, 1

$\mathrm{F}_{\mathrm{PV}}=$ Super Compressibility factor, 1

$\mathrm{F}_{\mathrm{M}}=$ Manometer correction factor, 1

$\mathrm{F}_{\mathrm{AA}}=$ Thermal expansion correction factor, $2.9786^{-9} * \mathrm{~T}^{2}+1.2620^{-5}(\mathrm{~T})+0.99912$

$\mathrm{T}=$ Temperature in degrees Fahrenheit

$\mathrm{F}_{\mathrm{L}}=$ Location factor, 1

$\sqrt{h_{w}}=$ Square root of the differential pressure measured by the Annubar

$\sqrt{\rho_{F}}=$ Square root of the fluid density 


\subsubsection{MEMS Emissions Measurement}

MEMS emissions measurements are raw exhaust samples that are collected from a stainless steel probe with holes around its circumference and its length. These samples, which are taken directly from the tailpipe, flow directly to a heated line then to a heated filter to collect any exhaust particulate. The raw exhaust then passes through a $\mathrm{NO}_{\mathrm{X}}$ converter that converts the $\mathrm{NO}_{\mathrm{X}}$ to NO. The sample then passes through a MEXA-720 analyzer that measures $\mathrm{NO}_{\mathrm{X}}$ concentration. The sample then passes through another filter before entering the pump. From the pump the raw exhaust gas passes through a thermoelectric chiller (Peltier elements) to condense out water vapor before entering the dry gas analyzers. The condensed water then exits the emissions measurement box through a drain. Out of the chiller the flow is directed in two directions. One stream enters a Horiba BE-140 analyzer that measures $\mathrm{CO}_{2}$. The other stream is directed to an electrochemical cell to measure $\mathrm{NO}_{\mathrm{X}}$ as a QA/QC measurement. These samples then meet up again and are vented outside the box. Figure 9 is view of the inside of the emissions box. 


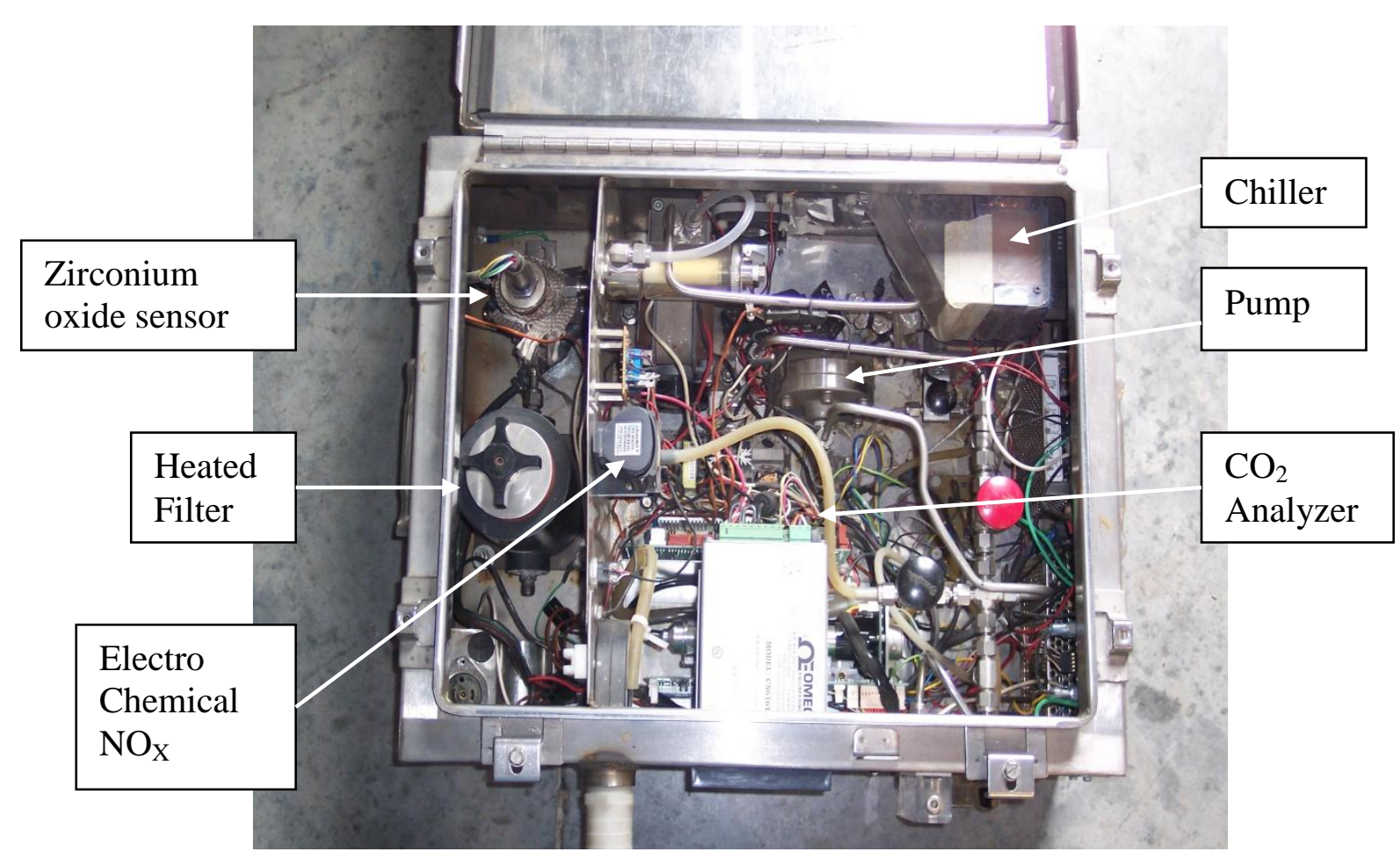

Figure 9 Emissions Sample Conditioning and Measurement System

\subsubsection{Horiba MEXA-720}

The MEXA-720 analyzer implements a zirconium oxide $\left(\mathrm{ZrO}_{2}\right)$ sensor to measure $\mathrm{NO}_{\mathrm{X}}$ and oxygen concentrations [Figure 10]. The MEXA-720 measures $\mathrm{NO}_{\mathrm{X}}$ by dissociating it into $\mathrm{N}_{2}$ and $\mathrm{O}_{2}$. From there the MEXA-720 has two cavities separated by the zirconium oxide. As current is passed through the zirconium oxide oxygen moves from high concentration to low concentration and the current that it takes to do this is measured. From this current $\mathrm{NO}_{\mathrm{X}}$ concentration can be calculated [18]. 




Figure 10 Horiba MEXA-720[18]

\subsubsection{Horiba BE-140}

The Horiba BE-140 is a non-dispersive infrared analyzer (NDIR) [18]. This analyzer can simultaneously measure $\mathrm{CO}, \mathrm{CO}_{2}$ and $\mathrm{HC}$. A broadband of infrared light is emitted from one end of the sample cell as the light moves down the sample cell part of it is absorbed by the gases. On the other end of the sample cell is a detector for each of the gasses being measured and also one reference detector. Each detector has narrow frequency band that it measures, this frequency band is different for each detector. Between the light source and the detectors is a chopper wheel that only lets one detector receive light at a time. The detector then receives feedback from the reference detector, which is used to quantify the intensity of the original beam of light. The difference in the intensity between the two detectors is directly related to the energy absorbed by the gas, thus correlating to the gas concentration (Figure 11).

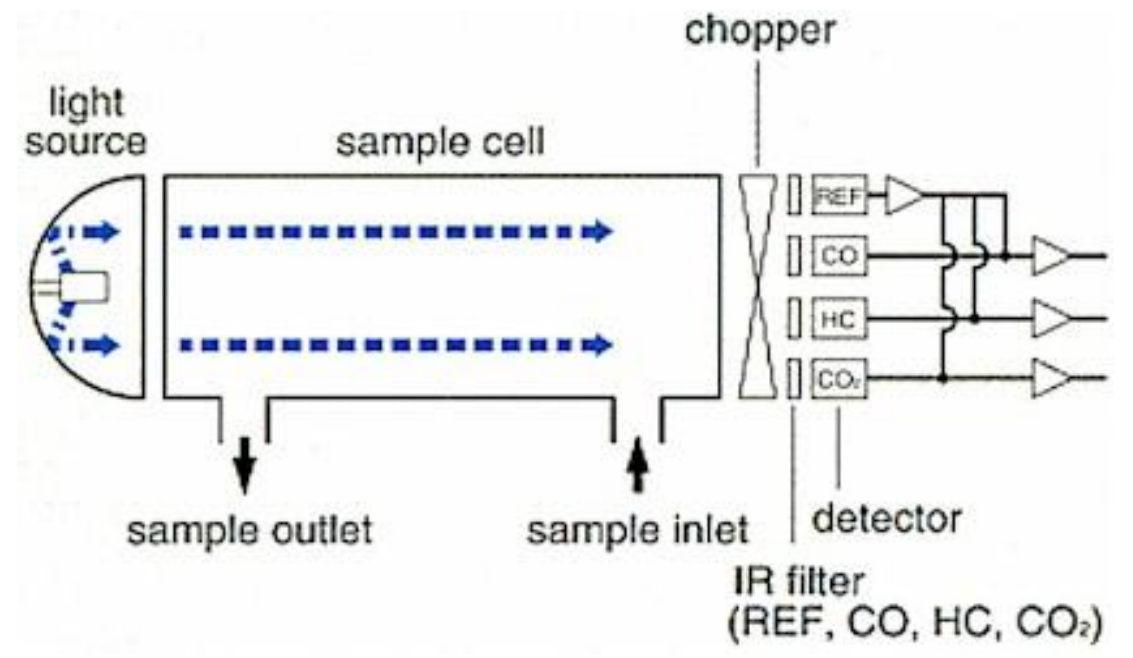

Figure 11 BE-140 Gaseous Emissions Measurement Micro-bench [18] 


\subsubsection{MEMS Data Acquisition}

The MEMS data acquisition system contains a National Instruments model SC-2345 data acquisition board housed inside a stainless steel box. The data acquisition board is connected to a laptop PC, the conditioned signals are recorded by a data acquisition program. This program is a Visual Basic program that saves and reduces the raw data from the flow emissions box. The program also log ECU data as well as GPS and ambient air temperature and pressure data.

\subsubsection{MEMS Calibrations}

\subsubsection{Introduction}

MEMS analyzers, transducers and thermocouples are calibrated using a linear fit of a multipoint calibration. Each transducer and thermocouple is calibrated before each set of test is performed. Emissions analyzers are also calibrated before each set of test and the intercept is reset after each test.

\subsubsection{Pressure Transducers}

Pressure transducers are calibrated before each set of tests. A multipoint calibration is used, usually a ten point calibration is done with points that span the range of the transducer. A Hiese $®$ is used to read the pressure and the data acquisition software is used to record the pressure from the Hiese as well as the transducers corresponding voltage. A hand pump is used to create the pressure or vacuum on the transducer. Both the differential pressure transducer and the absolute pressure transducer are calibrated in the same way. Then the data acquisition software does a linear regression of the data, this sets the slope and the intercept. To eliminate sensor drift the intercept is reset after every test.

\subsubsection{Thermocouple Modules}

Thermocouple modules were also calibrated with a ten point curve. The modules were sent a voltage by a Fluke thermocouple calibrator that sends a voltage that corresponds to a given temperature. This is based on the voltage differential of a new thermocouple at given 
temperature. Again the data acquisition software fits a line and an intercept to the calibration points. This intercept is also reset after each run.

\subsubsection{Emission Sensors Calibration}

Emissions analyzers were calibrated using standard MEMS procedures. A gas divider that could separate the gases in $10 \%$ increments was used. The balance gas for calibration was nitrogen and the componet gas was a $\mathrm{NO}_{\mathrm{X}}$ and $\mathrm{CO}_{2}$ mix with a known concentration of each. The $\mathrm{BE}-$ 140, MEXA-720 and the electrochemical $\mathrm{NO}_{\mathrm{x}}$ analyzers were calibrated simultaneously. The analyzers were calibrated at $0 \%, 50 \%$ and $100 \%$. From this the calibration software used the voltage from the analyzer and the concentrations of each component gas to fit a line and intercept.

\subsubsection{Dry-to-Wet Conversion}

When $\mathrm{CO}_{2}$ is collected it is considered a dry measurement because the gas has already passed through the chiller which condenses out almost all water, because moisture affects the NDIR measurements. This now dry gas has a higher percentage of $\mathrm{CO}_{2}$ because of the absence of water vapor. A dry-to-wet conversion factor is applied to obtain the $\mathrm{CO}_{2}$ concentration. This is done by Equation 25 through Equation 27 The Mexa $\mathrm{NO}_{\mathrm{X}}$ measurement is said to be wet because the measurement takes place before the chiller thus the dry to wet conversion is not needed for $\mathrm{NO}_{\mathrm{x}}$. However, the electrochemical $\mathrm{NO}_{\mathrm{X}}$, is a dry gas measurement thus the dry-to-wet conversion is applied.

Wet Concentration $=K_{w} \times d r y$

Equation 25 


$$
K_{w}=1-\left(\frac{\alpha}{200}\right) \times C O_{2_{e}}-\left[\frac{1.608 \times H}{7000+1.608 \times H}\right]
$$

Equation 26

$$
H=\frac{73.478 R_{i} \times P_{d}^{-}}{P_{B}-\left(P_{d} \times \frac{R_{i}}{100}\right)}
$$

Equation 27

Where,

$\mathrm{R}_{\mathrm{i}}=$ Relative Humidity, in percent

$\mathrm{P}_{\mathrm{d}}=$ Saturated vapor pressure, in $\mathrm{mm} \mathrm{Hg}$ at the ambient dry bulb temperature

$\mathrm{P}_{\mathrm{B}}=$ Barometric pressure, $\mathrm{mm} \mathrm{Hg}$

\subsubsection{6 $\mathrm{NO}_{\mathrm{X}}$ Humidity Correction Factor}

The $\mathrm{NO}_{\mathrm{X}}$ correction factor that was used for MEMS reduction was obtained from Southwest Research Institute [19]. This correction factor was derived from experimental data from 60 different test points and can be seen in the following two equations. It should be noted that this is not the same $\mathrm{NO}_{\mathrm{X}}$ humidity correction factor found in the subsection of the previous chapter.

$$
\mathrm{KNO}_{\mathrm{X}}=\mathrm{Cl}+[\mathrm{C} 2 \mathrm{x}(\mathrm{TEMP}-25)]+[\mathrm{C} 3 \mathrm{x}(\text { HUMID }-10.71)]
$$

Equation 28

Where,

$$
\text { corrected } N o_{X}=\frac{\text { Observed } N O_{X}}{K N O_{X}}
$$

Equation 29

\subsubsection{Data Alignment}

The emissions data collected had inconsistency in their time alignments. The $\mathrm{CO}_{2}$ values originate from a different sensor that is downstream from the NOx and $\mathrm{O}_{2}$ sensors. There is a delay in the $\mathrm{CO}_{2}$ readings because of the distance the sample must travel and also the response 
time of the sensor. The values for $\mathrm{NOx}$ and $\mathrm{CO}_{2}$ were plotted with respect to time. The $\mathrm{CO}_{2}$ was then shifted to provide proper alignment with the $\mathrm{NO}_{\mathrm{X}}$. Then $\mathrm{NO}_{\mathrm{X}}$ and $\mathrm{CO}_{2}$ were aligned with ECU data.

\subsubsection{Emissions Derived Fuel Consumption}

The amount of fuel consumed was calculated by combining the flow rate data and the $\mathrm{CO}_{2}$ concentrations. The weight of fuel consumed was calculated using Equation 30 through Equation 33 provided by CFR 40 Part 86 subpart N [14]. The weight of fuel was then converted to a volumetric quantity. The conversion was achieved by using the specific gravity of the fuel. The mass of $\mathrm{CO}$ and $\mathrm{HC}$ were assumed to be zero.

$$
M=\frac{G_{s}}{R_{2}} \times \frac{1}{453.6}
$$

Equation 30

$M=$ Mass of fuel in lbs

$G_{s}=$ Grams of carbon measured

$R_{2}=$ The grams of carbon in the fuel per gram of fuel

$$
G_{s}=\left[\frac{12.011}{12.011+\alpha(1.008)}\right] H C_{\text {mass }}+0.429 C O_{\text {mass }}+0.273 C O_{2_{\text {mass }}}
$$

$$
R_{2}=\frac{12.011}{12.011+\alpha(1.008)}
$$

Equation 32 


$$
\mathrm{CO}_{2_{\text {mass }}}=\sum_{i=1}^{n}\left[\frac{\left(\mathrm{CO}_{2_{e}}\right)_{i}}{10^{6}} \times\left(V_{\text {mix }}\right)_{i} \times\left(\text { Density }_{\mathrm{CO}_{2}}\right) \times \Delta t\right]
$$

Equation 33

$\left(\mathrm{CO}_{2}\right)_{i}=$ instantaneous concentration of carbon dioxide

$\left(V_{\text {mix }}\right)_{i}=$ instantaneous volumetric flow rate

Density $_{\mathrm{CO}_{2}}=$ density of carbon dioxide $\left(51.81 \mathrm{~g} / \mathrm{ft}^{3}\right)$

$\Delta t=$ time step between data points

\subsubsection{Emissions Test Procedures - On-Road Testing}

On-Road emissions tests were conducted on the two test buses, with each bus tested on the three candidate fuels. The route for the on-road emissions test is a truncated MDT Route 7, as described in Section 4.2 . For the on-road testing, both vehicles were loaded to the weight that was used for the chassis dynamometer testing, i.e. both at 35,700 lbs. Lead weights, supplied by MDT, were loaded onto both buses for payload simulation. After the buses were loaded with lead bars, they were instrumented with West Virginia University's Mobile Emissions Measuring System (MEMS) to conduct the on-road tests. The installed MEMS system can be seen in Figure 12 and Figure 13. 


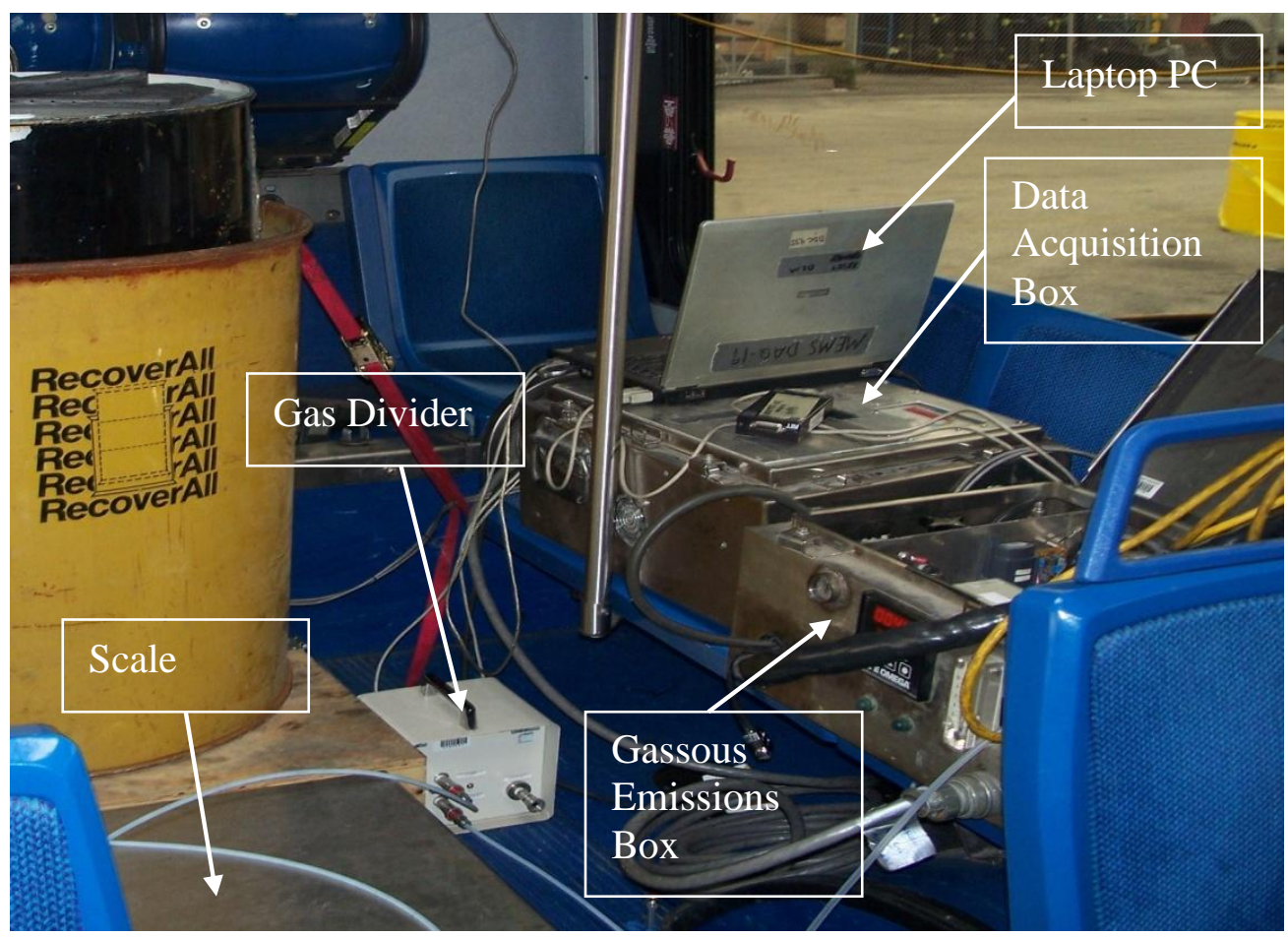

Figure 12 MEMS System Installed on MDT Bus

The exhaust flow measurement tube was mounted at the exit of the vehicles' exhaust systems. This tube also served as the sample location for the raw gaseous exhaust. Fuel lines were disconnected from the fuel tank and routed into the passenger area of the bus to a barrel which contained the fuel. By doing this, gravimetric fuel consumption could be measured and compared to $\mathrm{ECU}$ and $\mathrm{CO}_{2}$ balance fuel consumption. When a fuel was changed the fuel filters were also changed to ensure no residual fuel was left from the previous test fuel. Each vehicle was tested at least twice on each fuel. At the beginning of each test sequence, each analyzer was zeroed and spanned using a nitrogen balance gas and a mix $\mathrm{CO}_{2}$ and $\mathrm{NO}_{\mathrm{x}}$ as the component gas. The gas concentrations were $12.11 \% \mathrm{CO}_{2}$ and 2030ppm $\mathrm{NO}_{\mathrm{x}}$. Thermocouples and pressure transducers were also calibrated at the beginning of each test sequence. Before a test began, the chiller was drained to remove any condensation that had condensed out during the calibration. As a test was being started the fuel barrel was weighed to get a pre-weight. The full MEMS test route was broken into two legs to eliminate problems with sensor drift that is common in long duration tests. Immediately following the end of each leg, the fuel was weighed to get a postweight for the gravimetric fuel consumption measurements. Then the analyzers were again 
zeroed and spanned and the pressure transducers were re-zeroed. The chiller was again drained and the fuel was weighed at the beginning and end of the second leg.

ECU data were collected continuously for each test. Two different protocols were used to collect the ECU data: SAE J1587 and SAE J1939. Both protocols were read by using a Dearborn Protocol Adapter (DPA). SAE J1587 was logged continuously through the MEMS software and the SAE J1939 was collected on a separate laptop using the Dearborn Group's Data Link Monitor (DLM) software. Both ECU data streams were used in the final calculation of reported MEMS data.

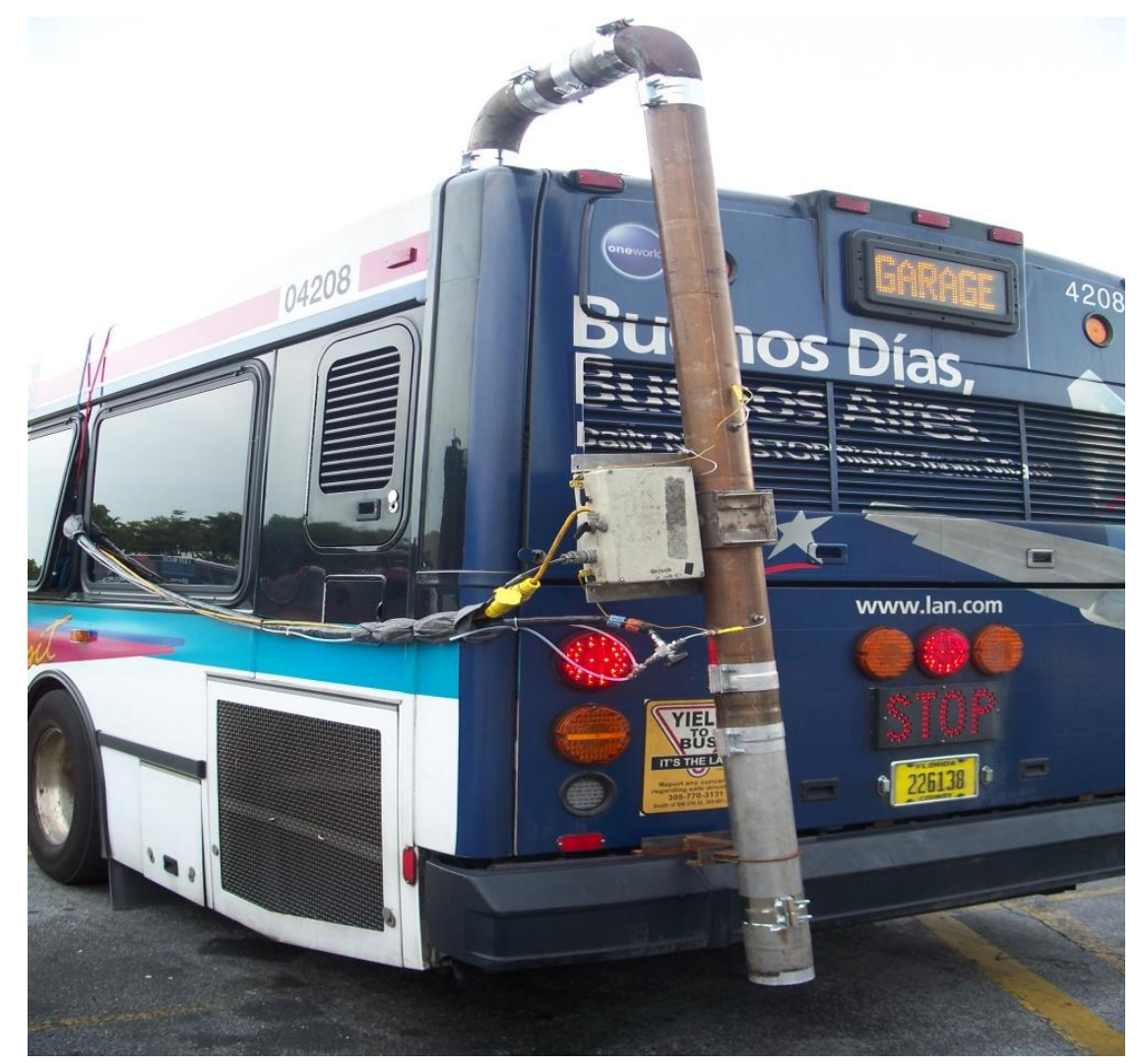

Figure 13 MEMS Exhaust Flow Measurement Device and Exhaust Sample Tube Installed on MDT Bus 


\section{EXPERIMENTAL PROCEDURE}

\subsection{Introduction}

Two MDT buses were tested for fuel economy and performance. A 2004 NABI, powered by a 2004 DDC Series 50, and a 2005 NABI, powered by a 2005 Cummins ISM were identified by MDT officials as being most representative of the current fleet. Both vehicles were evaluated with three different fuels - ultra-low sulfur diesel (ULSD), a 20\% soybean oil-based bio-diesel blend (B20-soybean oil), and a 20\% palm oil-based bio-diesel blend (B20-palm oil). Both vehicles were tested on a vehicle chassis dynamometer, as well as evaluated on-road, using mobile test equipment. An overview of the research conducted during this study is included below.

\subsection{Development of Miami-Dade Transit (MDT) Cycle}

In order to provide a more representative evaluation of actual on-road performance, while maintaining a controlled laboratory environment, a Miami Dade Transit (MDT) test cycle was developed to exercise the test vehicles on the heavy-duty vehicle chassis dynamometer. Accurate representation of in-use activity required acquisition of speed and torque data from ECU broadcast while the vehicle was driven through a typical transit route. These data were thoroughly analyzed and a 1430 seconds long chassis-dynamometer driving cycle (time vs. speed cycle) was developed, which is representative of the actual duty cycle that the vehicles undergo during revenue service. Details of this procedure are included below, in $\S 5.1$

\subsection{Chassis Dynamometer Tests}

Both vehicles were tested using WVU's Transportable Heavy-Duty Vehicle Emissions Testing Laboratory. The MDT cycle was used to discern the impact that the various fuels had on exhaust emissions and fuel economy. For each fuel, a warm-up cycle was conducted at the onset of the test sequence in order to pre-condition the vehicle. This was followed by a 20 -minute soak 
period to stabilize the vehicle. A minimum of three warm-start test cycles were then conducted, each followed by a 20-minute soak, in order to provide a data population for averaging.

Acceleration performance tests were conducted, whereby the vehicles were repeatedly accelerated from 0 to $20 \mathrm{mph}$ in order to quantify any differences in performance that could be associated with the use of the various fuel blends. During these tests, emissions measurements and fuel economy data were also collected.

\subsection{In-use Testing}

WVU's Mobile Emissions Measurement System (MEMS) was used to measure the in-use mass emissions of $\mathrm{NOx}$ and $\mathrm{CO}_{2}$ on a distance-specific (g/mile) and brake specific (g/bhp-hr) basis. For this phase of the program, in-use tests were conducted over the original on-road transit route (a truncated version of the MDT route 7) that was used to develop the MDT transient vehicle chassis test cycle. Gravimetric fuel consumption as well as vehicle ECM information were also collected during the in-use tests. Both vehicles were operated over the truncated route 7 for each of the three fuels. 


\section{PRESENTATION OF RESULTS}

\subsection{Route Development}

Prior to the chassis dynamometer tests, on-road activity data were collected in order to develop a novel chassis dynamometer cycle that would be representative of the activity encountered by the MDT buses during regular service. The chassis dynamometer test cycle was developed using data collected in Miami from a truncated version of MDT route 7. This route was chosen because the frequency of stops and the speeds reached throughout were indicated by MDT officials to be representative of the various duty conditions encountered in MDT's overall bus operations. To efficiently conduct on-road emissions tests, a truncated version of route 7 was used. This truncated route was then separated into two parts, the first of which started at the Mall of the Americas and followed the MDT route to Le Jeune. The second leg started at Le Jeune and followed the original route back to the Mall of the Americas. A map of the transit route used during MDT cycle development is included as Figure 14.

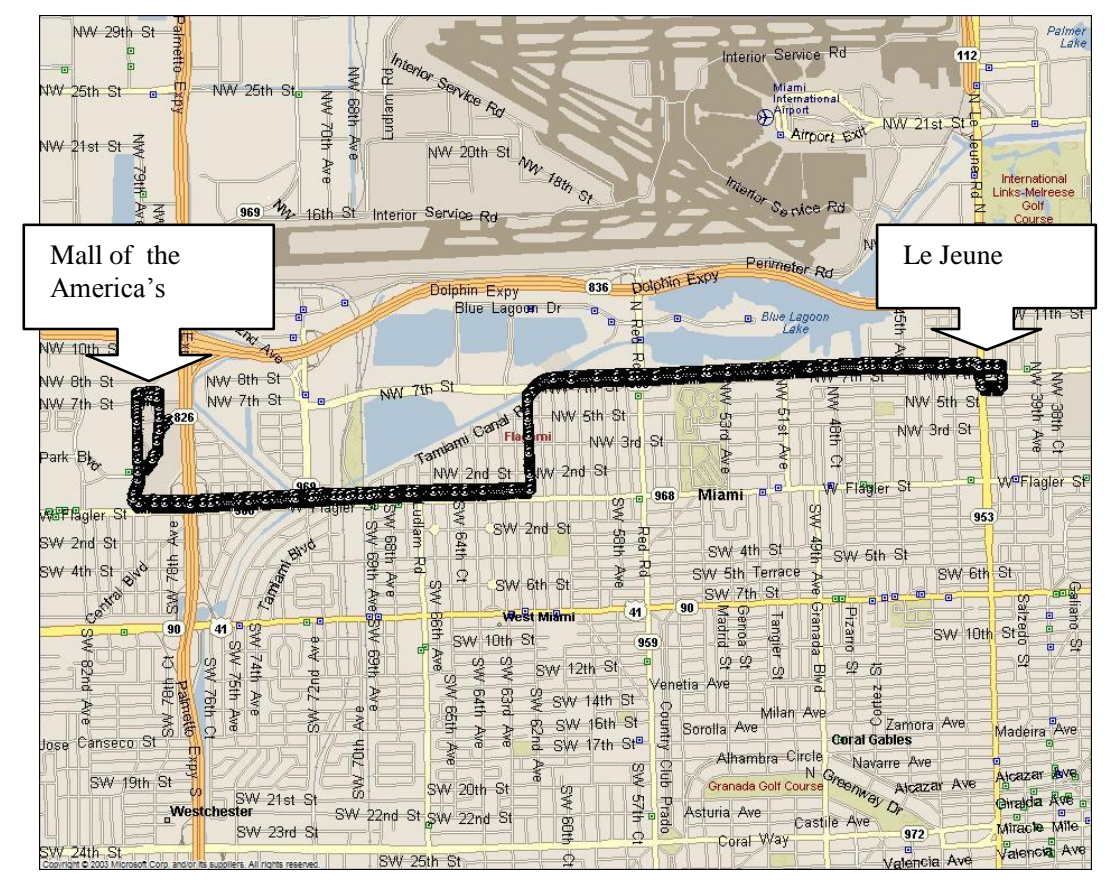

Figure 14 Map of Transit Route Used for MDT Cycle Development 
These data were collected by using a MDT bus that was loaded to $37,540 \mathrm{lb}$ which is approximately the weight that was to be used in the on-road and chassis testing. The bus that was used was equipped with a Series 50 Detroit Diesel. Engine parameters were measured through the ECU and included, but were not limited to, engine speed, torque, vehicle speed and fuel consumption. A total of three runs were conducted for analysis of driving conditions. Figure 15 shows an instantaneous speed trace of the test route that was approximately 3100 seconds.



\section{Figure 15 Speed vs. Time Trace of the Original Transit Route Used for MDT Cycle Development}

A Chi ${ }^{2}$ statistical analysis was employed to shorten the collected data to a 20 to 25 minute chassis test cycle that would represent the three test runs. Data taken during these runs were separated into 22 different micro-events; vehicle speed in $5 \mathrm{MPH}$ increments up to $35 \mathrm{MPH}$ and in each of those micro-events there were micro-trips of acceleration, deceleration, cruise, and in the $0-5 \mathrm{MPH}$ category there was also idle. These micro-events and the total time the vehicle spent in each of them can be seen in Figure 15. To be classified as an acceleration event, the 
vehicle had to accelerate at least $2 \mathrm{mi} / \mathrm{h} / \mathrm{s}$. The inverse was true for a deceleration event, the vehicle had to experience an acceleration of $-2 \mathrm{mi} / \mathrm{hr} / \mathrm{s}$. Cruise was defined as any acceleration between $+2 \mathrm{mi} / \mathrm{hr} / \mathrm{s}$ and $-2 \mathrm{mi} / \mathrm{hr} / \mathrm{s}$. The idle micro-trip was defined as any time the velocity of the vehicle went to zero.

In the development test routes that were completed, the bus came to rest for a few seconds at every route 7 bus stop. The number of stops was counted to know the total number of bus stops that would be encountered on this route. It was estimated that the average stop duration was between 30 and 90 seconds, and that the bus stops had passengers waiting to board approximately 70 percent of the time. From these estimates, idle time was added to the collected data by generating a random set of numbers between 30 and 90 seconds. These idle periods were then introduced into the cycle to represent 70 percent of the stops. The other 30 percent of the stops were forced to remain at cruising speed. Figure 16 shows the vehicle speed trace after the stops have been added.

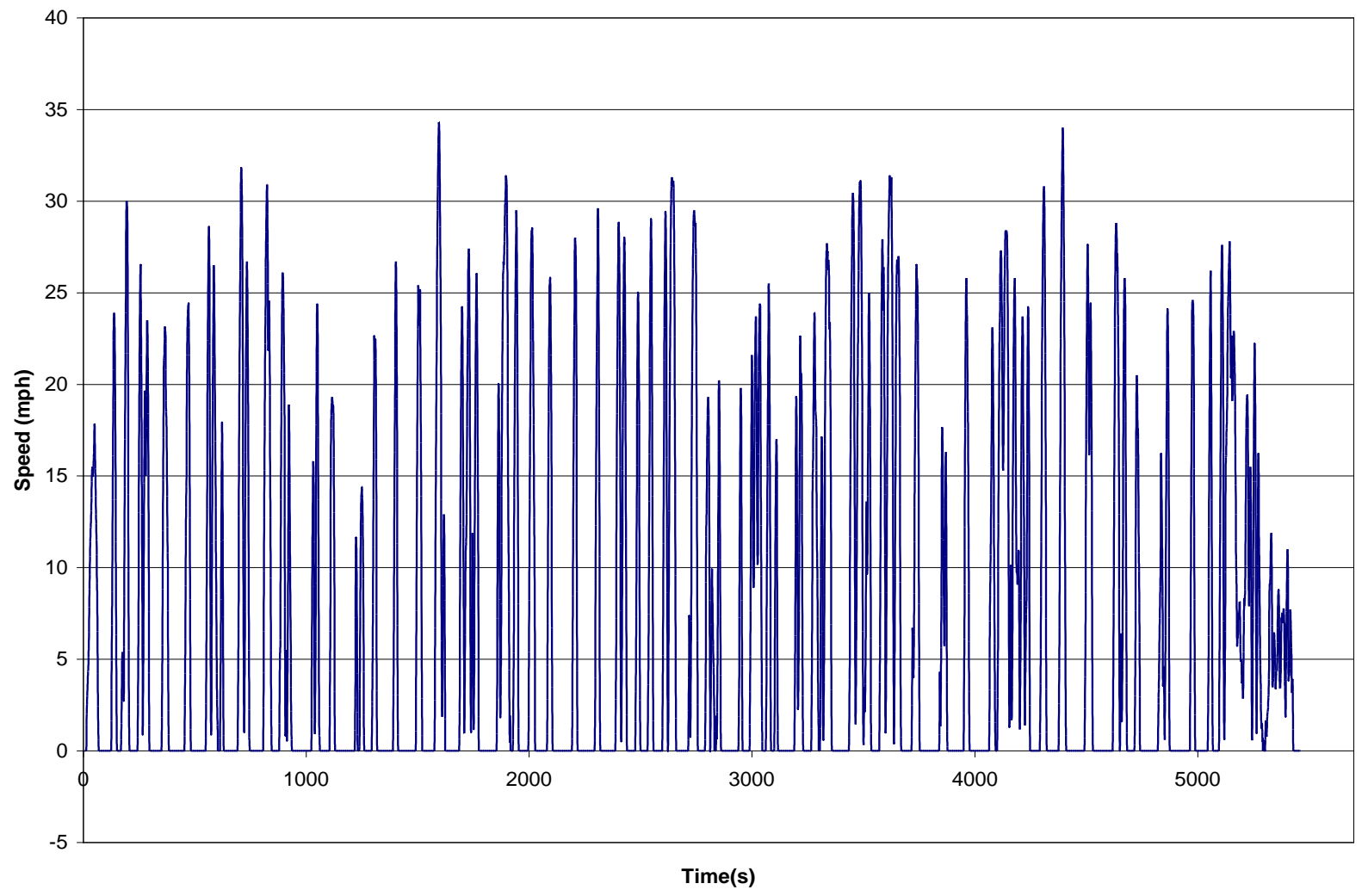

Figure 16 MDT Cycle with Bus Stop Idle Activity Included 
From this new set of instantaneous data, each data point was categorized into one of 22 identified micro-events. The percent of time the vehicle spent in each micro-trip was then calculated, and integration of these events was performed in order to form a representative test cycle. This cycle was then categorized in the same manner as the original and percent time in each micro-event was calculated. This percent time was then multiplied by the number of seconds in the original data set to normalize it to the original data. The $\mathrm{Chi}^{2}$ equation was then invoked.

Qbserved-Expected

Expected

Equation 34

These results can also be seen in Table 2 through Table 5.

Table 2 Acceleration Micro-Events

\begin{tabular}{||l|r|r|r|r|r||}
\hline \hline Acceleration & $\begin{array}{c}\text { Shortened Cycle } \\
\text { Percent Time }\end{array}$ & $\begin{array}{c}\text { In-Use } \\
\text { Percent Time }\end{array}$ & $\begin{array}{c}\text { Normalized } \\
\text { shortened cycle }\end{array}$ & $\begin{array}{c}\text { Normalized } \\
\text { In-Use }\end{array}$ & $(\mathrm{O}-\mathrm{E})^{\wedge} 2 / \mathrm{E}$ \\
\hline $0-5 \mathrm{mph}$ & $4.90 \%$ & $5.17 \%$ & 266.98 & 282.10 & 0.810 \\
\hline $5-10 \mathrm{mph}$ & $3.36 \%$ & $3.89 \%$ & 183.07 & 212.00 & 3.947 \\
\hline $10-15 \mathrm{mph}$ & $3.64 \%$ & $3.54 \%$ & 198.33 & 193.00 & 0.147 \\
\hline $15-20 \mathrm{mph}$ & $3.43 \%$ & $3.47 \%$ & 186.89 & 189.00 & 0.023 \\
\hline $20-25 \mathrm{mph}$ & $3.99 \%$ & $3.87 \%$ & 217.40 & 211.00 & 0.193 \\
\hline $25-30 \mathrm{mph}$ & $2.03 \%$ & $2.33 \%$ & 110.61 & 127.00 & 2.116 \\
\hline $30-35 \mathrm{mph}$ & $0.28 \%$ & $0.39 \%$ & 15.26 & 21.00 & 1.571 \\
\hline
\end{tabular}

Table 3 Deceleration Micro-Events

\begin{tabular}{||l|r|r|r|r|r||}
\hline \hline Deceleration & $\begin{array}{c}\text { Shortened Cycle } \\
\text { Percent Time }\end{array}$ & $\begin{array}{c}\text { In-Use } \\
\text { Percent Time }\end{array}$ & $\begin{array}{c}\text { Normalized } \\
\text { shortened cycle }\end{array}$ & $\begin{array}{c}\text { Normalized } \\
\text { In-Use }\end{array}$ & $($ O-E)^2/E \\
\hline $0-5 \mathrm{mph}$ & $4.34 \%$ & $4.20 \%$ & 236.47 & 229.08 & 0.237 \\
\hline $5-10 \mathrm{mph}$ & $2.87 \%$ & $3.10 \%$ & 156.37 & 169.00 & 0.943 \\
\hline $10-15 \mathrm{mph}$ & $3.29 \%$ & $3.12 \%$ & 179.26 & 170.00 & 0.504 \\
\hline $15-20 \mathrm{mph}$ & $3.22 \%$ & $2.93 \%$ & 175.44 & 160.00 & 1.490 \\
\hline $20-25 \mathrm{mph}$ & $3.15 \%$ & $3.10 \%$ & 171.63 & 169.00 & 0.040 \\
\hline $25-30 \mathrm{mph}$ & $1.75 \%$ & $1.87 \%$ & 95.35 & 102.00 & 0.433 \\
\hline $30-35 \mathrm{mph}$ & $0.28 \%$ & $0.29 \%$ & 15.26 & 16.00 & 0.034 \\
\hline \hline
\end{tabular}


Table 4 Cruise Micro-Events

\begin{tabular}{||l|r|r|r|r|r||}
\hline \multicolumn{1}{|c|}{ Cruise } & $\begin{array}{c}\text { Shortened } \\
\text { Cycle Percent } \\
\text { Time }\end{array}$ & $\begin{array}{c}\text { In-Use } \\
\text { Percent Time }\end{array}$ & $\begin{array}{c}\text { Normalized } \\
\text { shortened } \\
\text { cycle }\end{array}$ & $\begin{array}{c}\text { Normalized } \\
\text { In-Use }\end{array}$ & $\begin{array}{c}\text { (O- } \\
\text { E)^2/E }\end{array}$ \\
\hline $0-5 \mathrm{mph}$ & $1.12 \%$ & $1.03 \%$ & 61.02 & 56.02 & 0.446 \\
\hline $5-10 \mathrm{mph}$ & $0.91 \%$ & $0.79 \%$ & 49.58 & 43.00 & 1.007 \\
\hline $10-15 \mathrm{mph}$ & $0.28 \%$ & $0.29 \%$ & 15.26 & 16.00 & 0.034 \\
\hline $15-20 \mathrm{mph}$ & $0.70 \%$ & $0.59 \%$ & 38.14 & 32.00 & 1.178 \\
\hline $20-25 \mathrm{mph}$ & $0.91 \%$ & $0.59 \%$ & 49.58 & 32.00 & 9.660 \\
\hline $25-30 \mathrm{mph}$ & $1.26 \%$ & $1.30 \%$ & 68.65 & 71.00 & 0.077 \\
\hline $30-35 \mathrm{mph}$ & $0.63 \%$ & $0.62 \%$ & 34.33 & 34.00 & 0.003 \\
\hline
\end{tabular}

Table 5 Idle Micro-Events

\begin{tabular}{||c|r|r|r|r|r||}
\hline \hline Idle & $\begin{array}{c}\text { Shortened } \\
\text { Cycle Percent } \\
\text { Time }\end{array}$ & $\begin{array}{c}\text { In-Use } \\
\text { Percent Time }\end{array}$ & $\begin{array}{c}\text { Normalized } \\
\text { shortened } \\
\text { cycle }\end{array}$ & $\begin{array}{c}\text { Normalized } \\
\text { In-Use }\end{array}$ & $(\mathrm{O}-\mathrm{E})^{\wedge} 2 / \mathrm{E}$ \\
\hline $0-5 \mathrm{mph}$ & $53.78 \%$ & $53.54 \%$ & 2932.96 & 2920.07 & 0.056 \\
\hline
\end{tabular}

A calculated $\mathrm{Chi}^{2}$ distribution based on 22 degrees of freedom and a 25 percent significance level is 26.039. Since the sum of the $\mathrm{Chi}^{2}$ is 24.960and this is less than the $\mathrm{Chi}^{2}$ distribution number, then this cycle can be said to be statistically representative of the original cycle. Figure 17 below illustrates the WVU MDT transient cycle used for the chassis dynamometer tests. 


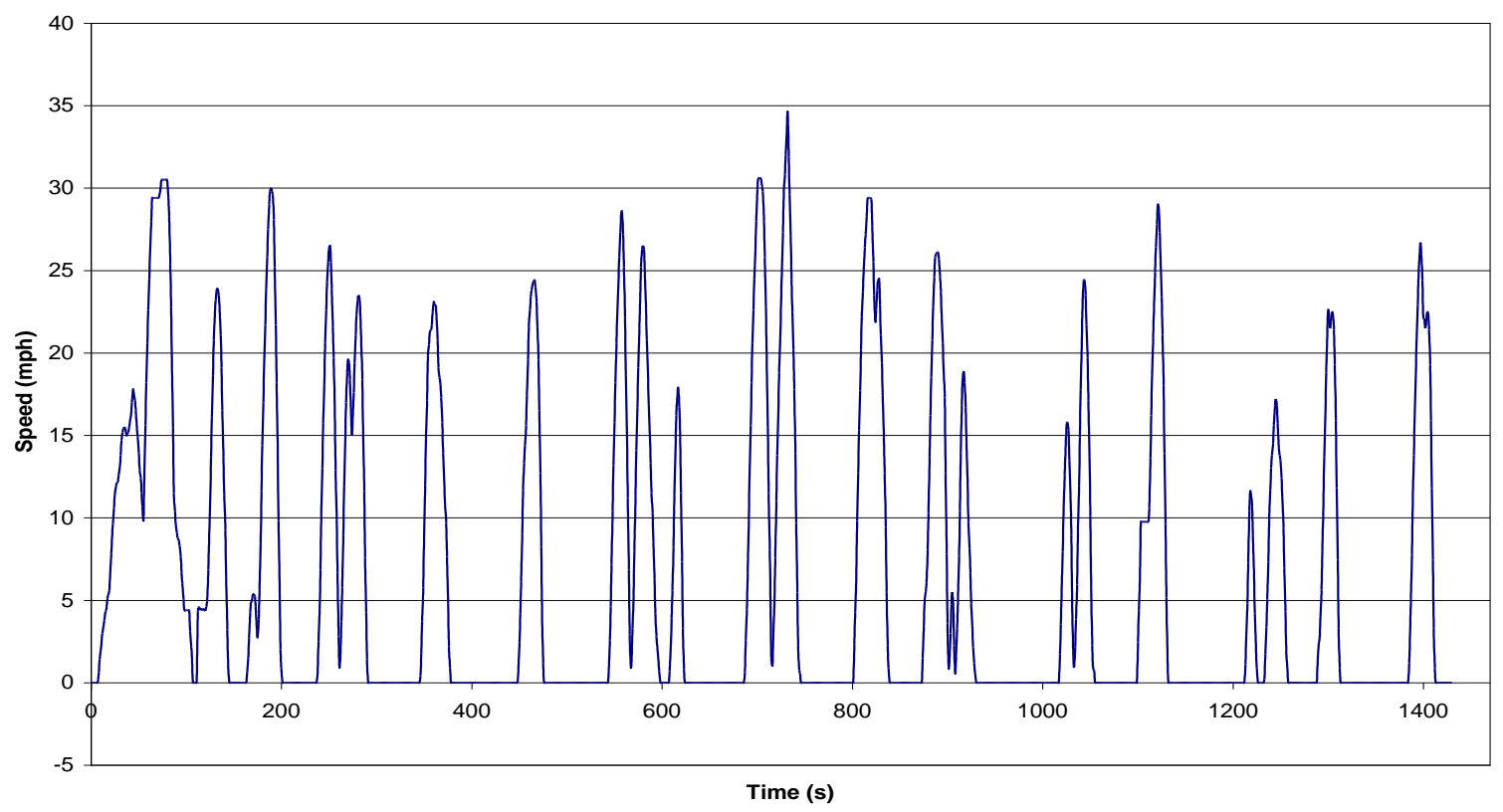

Figure 17 Speed vs. Time trace of the WVU MDT Transient Chassis Dynamometer Cycle

\subsection{Results from Chassis Dynamometer Testing}

Both of the test vehicles were exercised over the MDT bus cycle, as well as an additional acceleration cycle, wherein the vehicle was repeatedly accelerated from 0 to $20 \mathrm{mph}$ in order to quantify the effects of the different fuels on vehicle acceleration. Measurement of mass emissions of total particulate matter, oxides of nitrogen, total hydrocarbons, carbon monoxide, and carbon dioxide were made, as well as vehicle fuel consumption. Fuel consumption data were collected from direct gravimetric measurement, emissions carbon balance inference, and ECU fueling information. Data presentation of the chassis dynamometer tests has been divided into two sections, MDT cycle and acceleration cycles, which follow. 


\subsubsection{Chassis Dynamometer Emissions and Fuel Economy Test Results - MDT Cycle}

Tabulated results from the emissions tests conducted on the chassis dynamometer using the MDT bus cycle are included in Appendix A. These results show that for the DDC Series 50 powered bus a increase of $2-3 \%$ was seen in $\mathrm{NO}_{\mathrm{X}}$ with the use of both biodiesel fuels. Emissions of $\mathrm{HC}$ increased as much as $10 \%$, but it should be noted that the $\mathrm{HC}$ measurements were taken near the resolution of the analyzer which could account for the large test-to-test variation. A reduction of $8-11 \%$ were seen in the emissions of $\mathrm{CO}$ with the biofuels while PM was reduced by $27-31 \%$ over its ULSD counterpart.

The Cummins powered bus actually seen a reduction in $\mathrm{NO}_{\mathrm{X}}$ with the use of both biodiesel fuels, on the order of 4-5\% over the ULSD baseline. Reductions in CO and PM were experienced, on the order of $7-15 \%$ and $21-31 \%$ respectively, with the use of both biodiesel fuels. Measurements of $\mathrm{HC}$ emissions showed a reduction with the use of the soy-based biodiesel and no change in HC emissions with the use of the palm-based biodiesel.

Carbon dioxide emissions are an indication of the amount of fuel consumed, as most of the carbon in the fuel is converted into $\mathrm{CO}_{2}$ during combustion. Emissions of $\mathrm{CO}_{2}$ for the bus powered by the DDC engine showed reductions of less then $1 \%$ with the use of both biodiesel fuels, while fuel economy increased by 5-6\%. Test results from the Cummins powered bus showed decreases in $\mathrm{CO}_{2}$ emissions of less then $1 \%$ as well, while fuel economy was increased by $6-8 \%$. The trends in $\mathrm{CO}_{2}$ emissions follow the same trends observed in the fuel consumption data which qualitatively confirms the observed fuel consumption results. The small percent difference in $\mathrm{CO}_{2}$ could be due to biodiesel having longer carbon chains thus more $\mathrm{CO}_{2}$ for a given amount of fuel. 


\subsubsection{Chassis Dynamometer Emissions Test Results - Acceleration Cycle}

Acceleration tests were conducted on each of the two busses with all three fuels. These tests were comprised of a series of accelerations, wherein the bus was accelerated from rest to a 20 mph then decelerated back to zero. During this acceleration, the driver commanded fueling at $100 \%$. This was repeated multiple times for each bus and fuel. The acceleration tests were performed on the chassis dynamometer to eliminate any differences that could affect the acceleration during on-road testing, such as traffic or grade. Results of these tests are shown graphically in Figure 18 through Figure 23 and these graphic results are summarized in Table 6 and Table 7. Figure 18 through Figure 20 show the accelerations of the DDC Series 50 bus, from these results you can see that the acceleration patters are very similar with the exception of the soy-based biodiesel. During the soy-based biodiesel acceleration test a shaft on the chassis dynamometer broke and ended the test early, this test was not re-run due to the time constraints of the project.

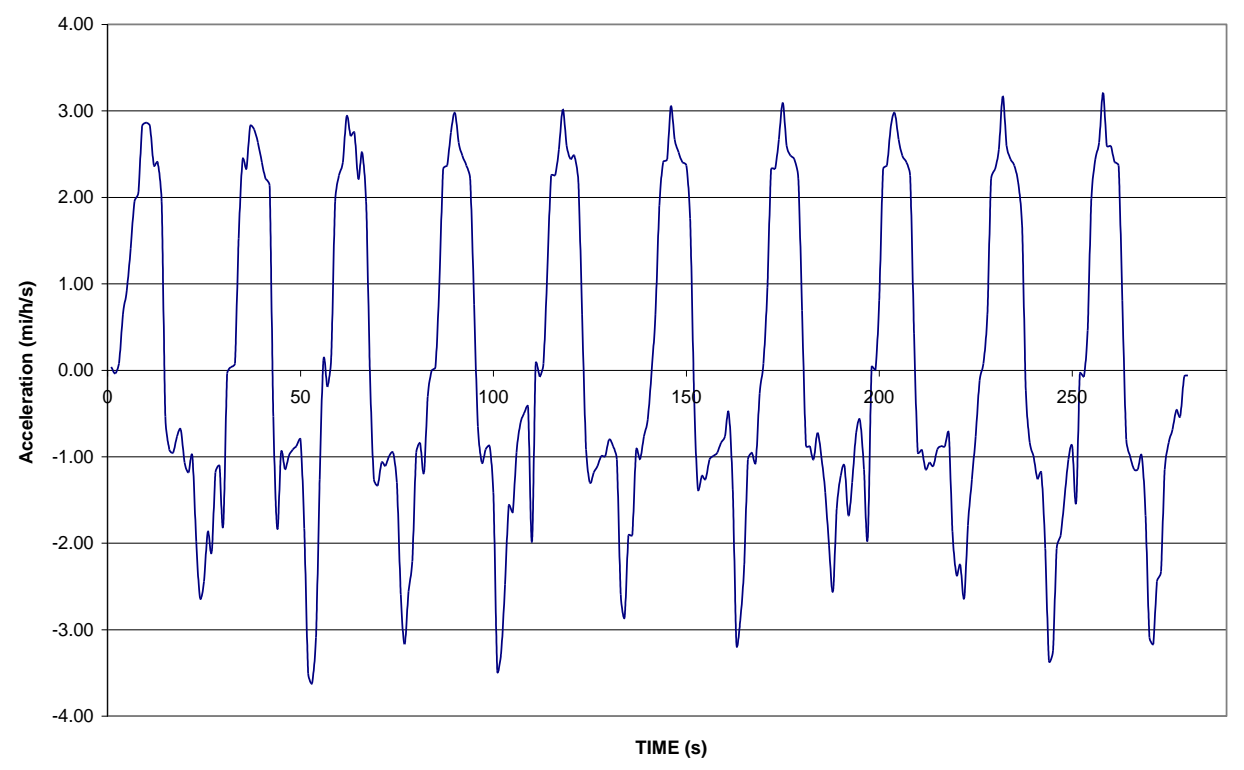

Figure 18 Acceleration vs. Time Trace of the Acceleration Test for Bus 04208 - DDC S50 with ULSD Fuel 


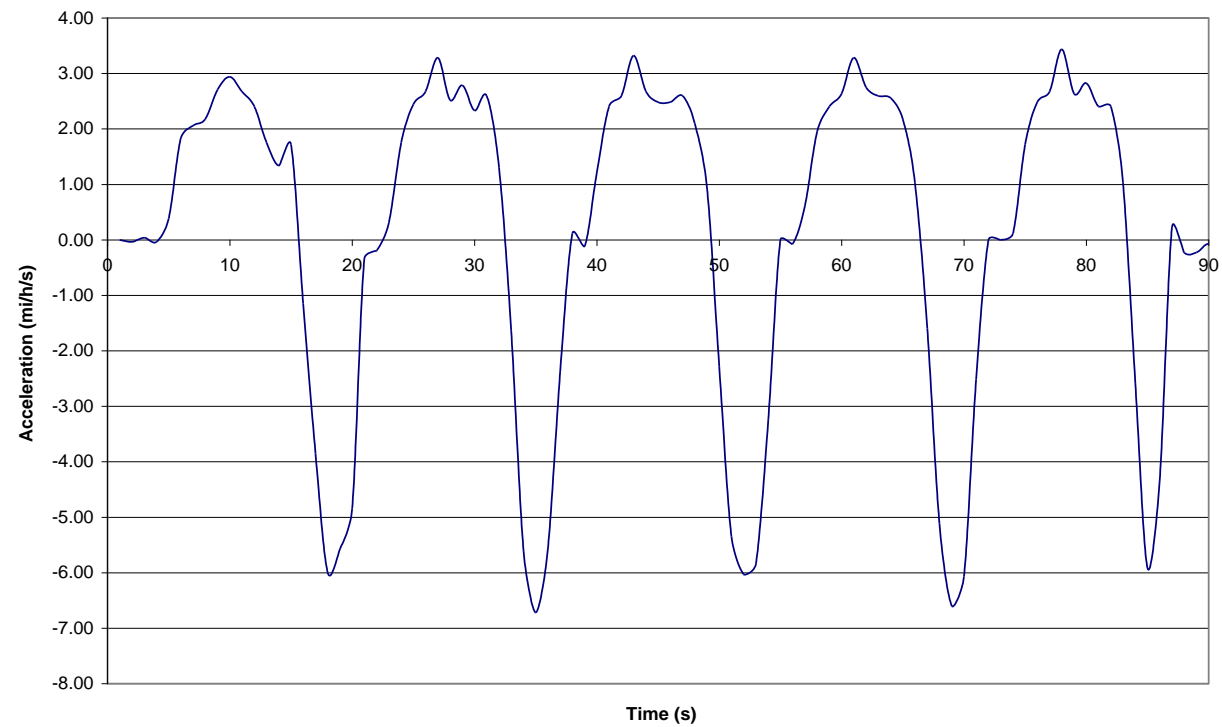

Figure 19 Acceleration vs. Time Trace of the Acceleration Test for Bus 04208 - DDC S50 with Soybean Oil B20



Figure 20 Acceleration vs. Time Trace of the Acceleration Test for Bus 04208 - DDC S50 with Palm Oil B20

Figure 21 through Figure 23 are the accelerations achieved by the Cummins ISM on the three candidate fuels, again the acceleration patterns are very similar with the highest accelerations being seen from the Palm oil-based biodiesel. 


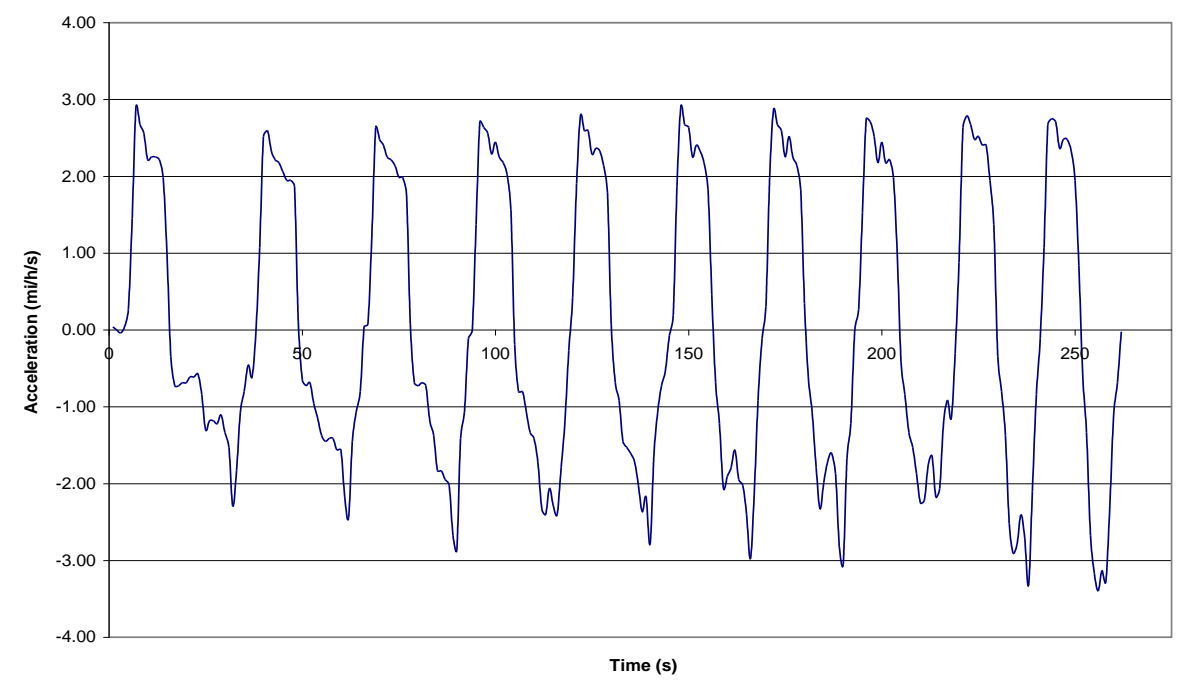

Figure 21 Acceleration vs. Time Trace of the Acceleration Test for Bus 05108 - Cummins ISM 280 with ULSD

Cummins ISM Soy Based Bio-Diesel Acceleration

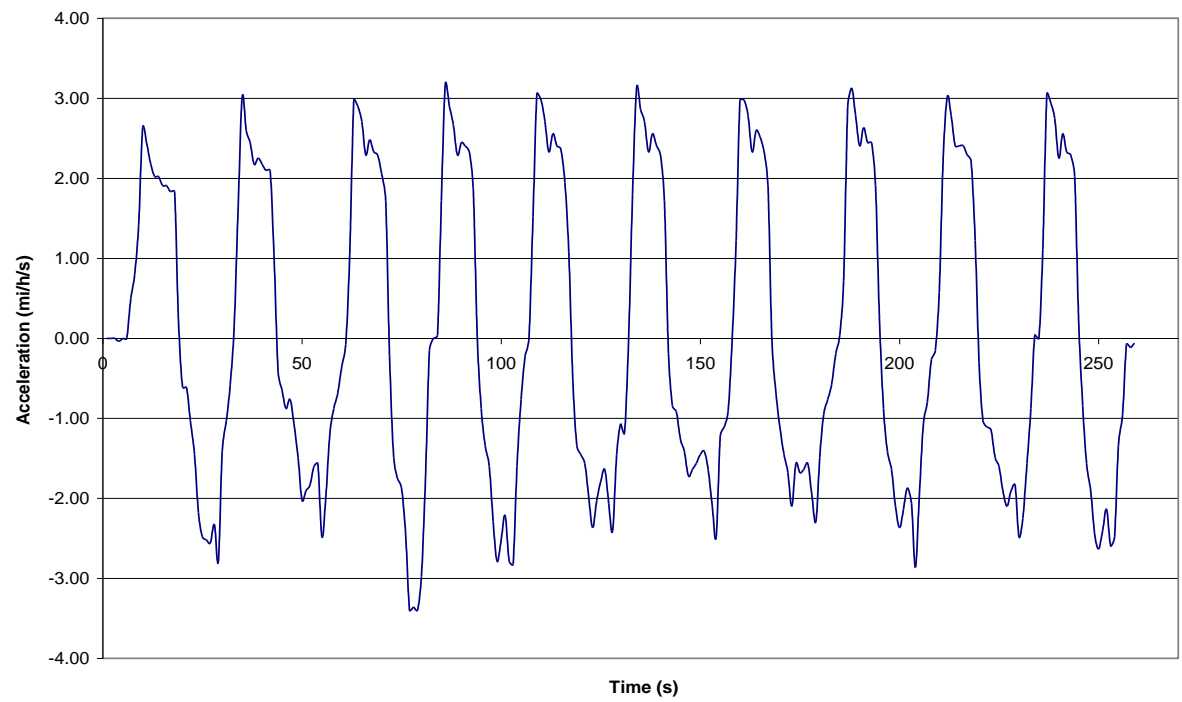

Figure 22 Acceleration vs. Time Trace of the Acceleration Test for Bus 05108 - Cummins ISM 280 with Soybean Oil B20 


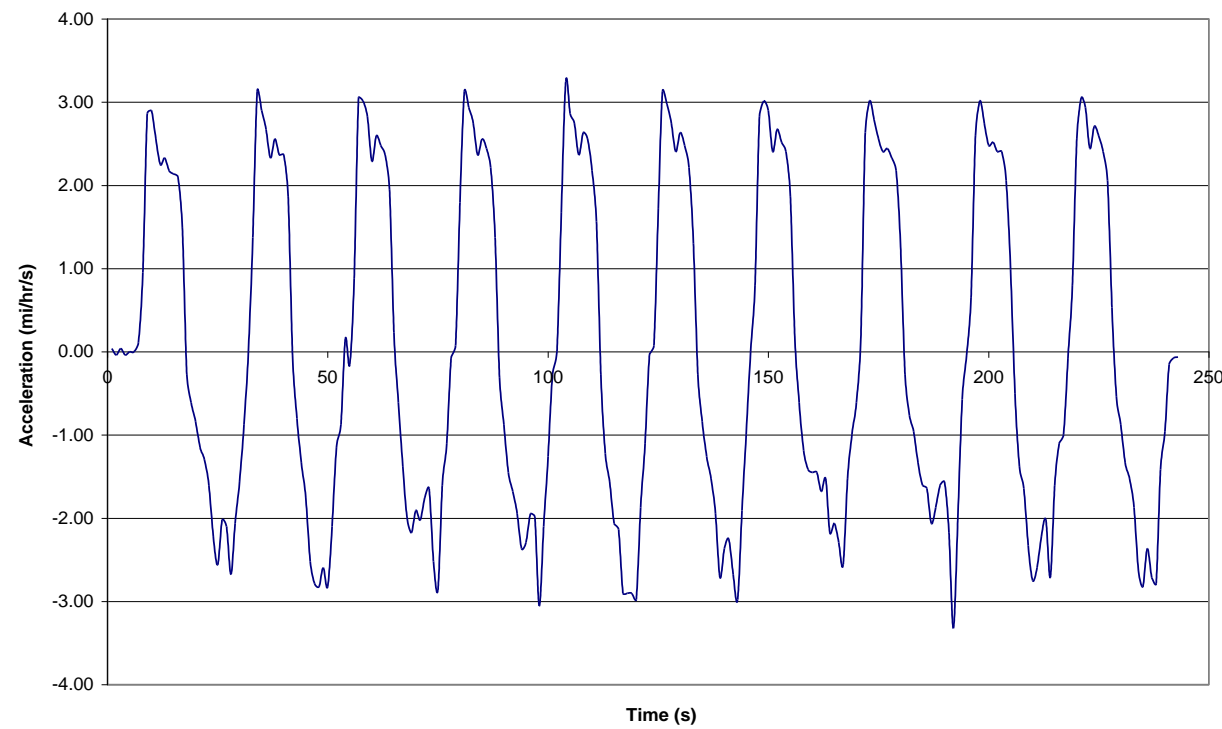

Figure 23 Acceleration vs. Time Trace of the Acceleration Test for Bus 05108 - Cummins ISM 280 with Palm Oil B20

Results for the acceleration test show that for both buses an increase in acceleration over ULSD was seen with the use of soybean oil-based biodiesel. While palm oil-based biodiesel exhibited an increase in acceleration over the ULSD when powering bus 05108 (Cummins powered), it showed a reduction in acceleration in bus 04208 (DDC powered). Emissions data as well as fuel economy data can be seen in Appendix B

Table 6 Summary of Maximum Accelerations for Bus 04208 - DDC S50

\begin{tabular}{||l|l|l||}
\hline \hline \multicolumn{3}{|c|}{ DDC series 50 } \\
\hline Fuel & $\begin{array}{l}\text { Max Acceleration Chassis } \\
(\mathrm{mi} / \mathrm{h} / \mathrm{s})\end{array}$ & $\begin{array}{l}0-20 \text { mph Time Chassis Tests } \\
(\mathrm{sec})\end{array}$ \\
\hline ULSD & 3.21 & 6.231 \\
\hline Soybean Oil B20 & 3.44 & 5.814 \\
\hline Palm Oil 20 & 3.17 & 6.309 \\
\hline
\end{tabular}


Table 7 Summary of Maximum Accelerations for Bus 05108 - Cummins ISM 280

\begin{tabular}{||l|l|lr||}
\hline \multicolumn{3}{|c|}{ Cummins ISM } \\
\hline Fuel & $\begin{array}{l}\text { Max Acceleration Chassis } \\
(\mathrm{mi} / \mathrm{h} / \mathrm{s})\end{array}$ & $\begin{array}{l}0-20 \text { mph Time Chassis Tests } \\
(\mathrm{sec})\end{array}$ \\
\hline ULSD & 2.9 & 6.897 \\
\hline Soybean Oil B20 & 3.17 & 6.309 \\
\hline Palm Oil 20 & 3.24 & 6.173 \\
\hline
\end{tabular}

\subsection{Results from On-Road Emissions Testing}

Both vehicles were instrumented and tested with WVU's MEMS during the on-road emissions and fuel consumption evaluations. Emissions data, ECU information, and gravimetric fuel consumption were simultaneously collected as the vehicle was operated over the original truncated route 7. Results presented herein are segregated according to emissions, fuel consumption, and vehicle acceleration performance.

\subsubsection{On-road Emissions Test Results}

On-road emissions results that were collected using WVU's MEMS system are included in Table 8 below, in both $\mathrm{g} / \mathrm{mile}$ and $\mathrm{g} / \mathrm{bhp}-\mathrm{hr}$. Typically, $\mathrm{CO}_{2}$ and $\mathrm{NO}_{\mathrm{x}}$ results from the tests using biofuels were lower than those data generated during the ULSD tests. However, as indicated, data collected during the testing of bus 04208 (DDC powered) with soybean oil-based biodiesel indicated a slight increase in brake-specific as well as distance-specific $\mathrm{NO}_{\mathrm{x}}$. In addition, data collected during the testing of bus 05108 (Cummins powered) with both biofuels indicated a slight increase in distance-specific $\mathrm{CO}_{2}$ over the baseline ULSD results. This increase in $\mathrm{CO}_{2}$ is a direct indication of increased fueling. 
Table 8 Averaged On-Road Emissions Results From Bus 04208 - DDC S50

\begin{tabular}{||l|c|c|c|c||}
\hline \hline DDC & \multicolumn{2}{|c|}{$\mathrm{g} / \mathrm{mile}$} & \multicolumn{2}{c||}{$\mathrm{g} / \mathrm{bhp}-\mathrm{h}$} \\
\hline Fuel & $\mathrm{CO}_{2}$ & $\mathrm{NO}_{\mathrm{x}}$ & $\mathrm{CO}_{2}$ & $\mathrm{NO}_{\mathrm{x}}$ \\
\hline ULSD & 4155.4 & 18.4 & 498.1 & 2.2 \\
\hline Soybean Oil B20 & 3938.7 & 18.5 & 486.4 & 2.3 \\
\hline Palm Oil B20 & 3401.6 & 15.3 & 489.8 & 2.2 \\
\hline$\%$ Diff Soybean Oil B20 & -5.2 & 0.7 & -2.4 & 3.2 \\
\hline$\%$ Diff Palm Oil B20 & -18.1 & -16.8 & -1.7 & -0.7 \\
\hline
\end{tabular}

Table 9 Averaged On-Road Emissions From Bus 05108 - Cummins ISM 280

\begin{tabular}{||l|c|c|c|c||}
\hline \hline Cummins & \multicolumn{2}{|c|}{$\mathrm{g} / \mathrm{mile}$} & \multicolumn{2}{c||}{$\mathrm{g} / \mathrm{bhp}-\mathrm{h}$} \\
\hline Fuel & $\mathrm{CO}_{2}$ & $\mathrm{NO}_{\mathrm{x}}$ & $\mathrm{CO}_{2}$ & $\mathrm{NO}_{\mathrm{x}}$ \\
\hline ULSD & 3926.1 & 18.2 & 497.8 & 2.3 \\
\hline Soybean Oil B20 & 3936.0 & 16.2 & 495.6 & 2.0 \\
\hline Palm Oil B20 & 4005.2 & 15.9 & 491.5 & 1.9 \\
\hline \% Diff Soybean Oil B20 & 0.3 & -11.1 & -0.4 & -13.4 \\
\hline \% Diff Palm Oil B20 & 2.0 & -12.7 & -1.3 & -17.7 \\
\hline
\end{tabular}

\subsubsection{On-road Fuel Consumption Results}

ECU reported and gravimetric fuel economy information is presented below in Table 10. Fuel economy data were integrated as a round trip (e.g. M190082-2 and M190082-3) in order to utilize a longer data set for more accurate fuel economy representation. This average was calculated as the quotient of round trip total mileage and fuel consumed. Data from bus 04208 (DDC powered) indicated an approximate 7\% fuel economy improvement when the vehicle was operated on biofuels. For this vehicle, the same driver was used for all on-road tests. Results from Bus 05108 (Cummins powered) indicated that operation on both biofuels resulted in an approximate $3.5 \%$ reduction in fuel economy, when compared to tests performed with ULSD. During the testing of Bus 05108, a substitute driver was required for the on-road tests using ULSD. The driver used for the testing of Bus 04208 drove Bus 05108 for both the palm oil- and soybean oil-based biodiesel tests. Although driving style and traffic patterns can have significant effects on vehicle fuel efficiency, the results from Bus 05108 tend to support findings of prior published literature $[3,4]$. 
Table 10 ECU and Gravimetric Fuel Economy Results for On-Road Tests

\begin{tabular}{|c|c|c|c|c|c|}
\hline \multicolumn{6}{|c|}{ Bus 04208 - DDC Series 50} \\
\hline Fuel & $\begin{array}{l}\text { ECU } \\
\text { Reported } \\
\text { Gallons }\end{array}$ & ECU MPG & $\begin{array}{l}\text { Gravimetric } \\
\text { Gallons }\end{array}$ & $\begin{array}{l}\text { Gravimetric } \\
\text { MPG }\end{array}$ & $\begin{array}{l}\% \\
\text { Difference }\end{array}$ \\
\hline ULSD & 4.18 & 2.33 & 4.4 & 2.21 & 4.99 \\
\hline Soybean Oil B20 & 3.88 & 2.48 & 4.57 & 2.11 & 15.06 \\
\hline Palm Oil B20 & 3.95 & 2.47 & 4.31 & 2.26 & 8.29 \\
\hline \multicolumn{6}{|c|}{ Bus 05108 - Cummins ISM } \\
\hline ULSD & 4.24 & 2.39 & 4.16 & 2.44 & -1.89 \\
\hline Soybean Oil B20 & 4.23 & 2.31 & 4.15 & 2.35 & -1.86 \\
\hline Palm Oil B20 & 4.23 & 2.3 & 4.14 & 2.35 & -2.15 \\
\hline
\end{tabular}

Since the fuel economy of the bus 04208 (DDC powered) goes against most published literature further analysis was done to determine if driving patterns may have affected the results of fuel economy. Though the vehicles were exercised over the same route, repeatability of certain parameters such as mileage and idle time were difficult to control. Distance variations were the product of the availability of on street parking where the tests were started and stopped and idle time variations arise from the traffic density from one test to the next. Thus the work done for each route was examined from a kinetic energy stand-point. The reason for examining the work from a kinetic energy metrix and not a torque basis is that torque is inferred from fueling in the ECU. The kinetic energy calculations were applied to continuous speed data. An absolute value of kinetic energy was not calculated but rather the change in kinetic energy $(\Delta \mathrm{KE})$.

$$
\Delta K E=\frac{1}{2} m v_{i+1}^{2}-\frac{1}{2} m v_{i}^{2}
$$

Equation 35

All negative values of kinetic energy were disregarded since this usually signifies little or no fueling for the aggressive driving styles exhibited over these test routes. The continuous data were also examined for all values of $\Delta \mathrm{KE}$ that were zero since this relates to the vehicle traveling at a constant velocity or at idle. Idle time was also included in determining equivalence of fuel economy since large idle time can have significant effects on fuel consumption. In Table 11 the 
results from this analysis can be seen. The work per mile and the total work both show that bus 04208 (DDC powered) when powered by ULSD had slightly larger values of work then the palm and soy based biodiesel. This analysis shows that for the soy-based biodiesel tests driving patterns were not a factor in the increase in fuel economy. However, for the palm-based biodiesel tests, driving patterns did play a role in the increase of fuel economy. The distance specific work for the palm-based biodiesel was $6 \%$ less than that of the ULSD which matches the $6 \%$ increase in fuel economy. In conclusion, the examination of the kinetic energy quantitatively supports the fuel economy results for the soy-based tests for bus 04208 (DDC powered) and adds insight to the fuel economy results for the palm-based tests. The kinetic energy analysis of bus 05108 (Cummins powered), however, shows that there is actually a smaller percent difference in fuel economy than was reported by the ECU since the distance specific work for the palm oil biodiesel was $2 \%$ greater than that of the ULSD and also had $13 \%$ greater idle time.

\section{Table 11 Estimated Work Over the Test Route}

\begin{tabular}{||l|c|c|c|c|c||}
\hline \hline \multicolumn{7}{|c||}{ Bus 04208- DDC Series 50 } \\
\hline Fuel & Work (KJ) & MPG & $\begin{array}{c}\text { Distance } \\
(\mathrm{mi})\end{array}$ & $\begin{array}{c}\text { Work/Distance } \\
(\mathrm{KJ} / \mathrm{mi})\end{array}$ & Percent idle time \\
\hline Ulsd & 38853 & 2.33 & 4.87 & 7978 & 43.7 \\
\hline Soy & 38196 & 2.48 & 4.8 & 7958 & 43.6 \\
\hline Palm & 36069 & 2.47 & 4.81 & 7499 & 45.2 \\
\hline \multicolumn{7}{|c||}{ Bus 05108 - Cummins ISM 280 } \\
\hline Ulsd & 33892 & 2.39 & 5.07 & 6685 & 37.5 \\
\hline Soy & 32584 & 2.31 & 4.87 & 6691 & 46 \\
\hline \hline Palm & 33165 & 2.3 & 4.85 & 6838 & 44.2 \\
\hline \hline
\end{tabular}

In Figure 24 through Figure 35 the speed versus time trace of each leg is shown. As expected for in-use testing the speed vs. time traces vary from one leg to the next but it is noted that all of them follow the trend of hard accelerations and decelerations and very little cruise time. Moreover long idle times are seen in each leg. The durations of each test very as much as 700 seconds, once again this is a byproduct of traffic patterns at the time of each test. 


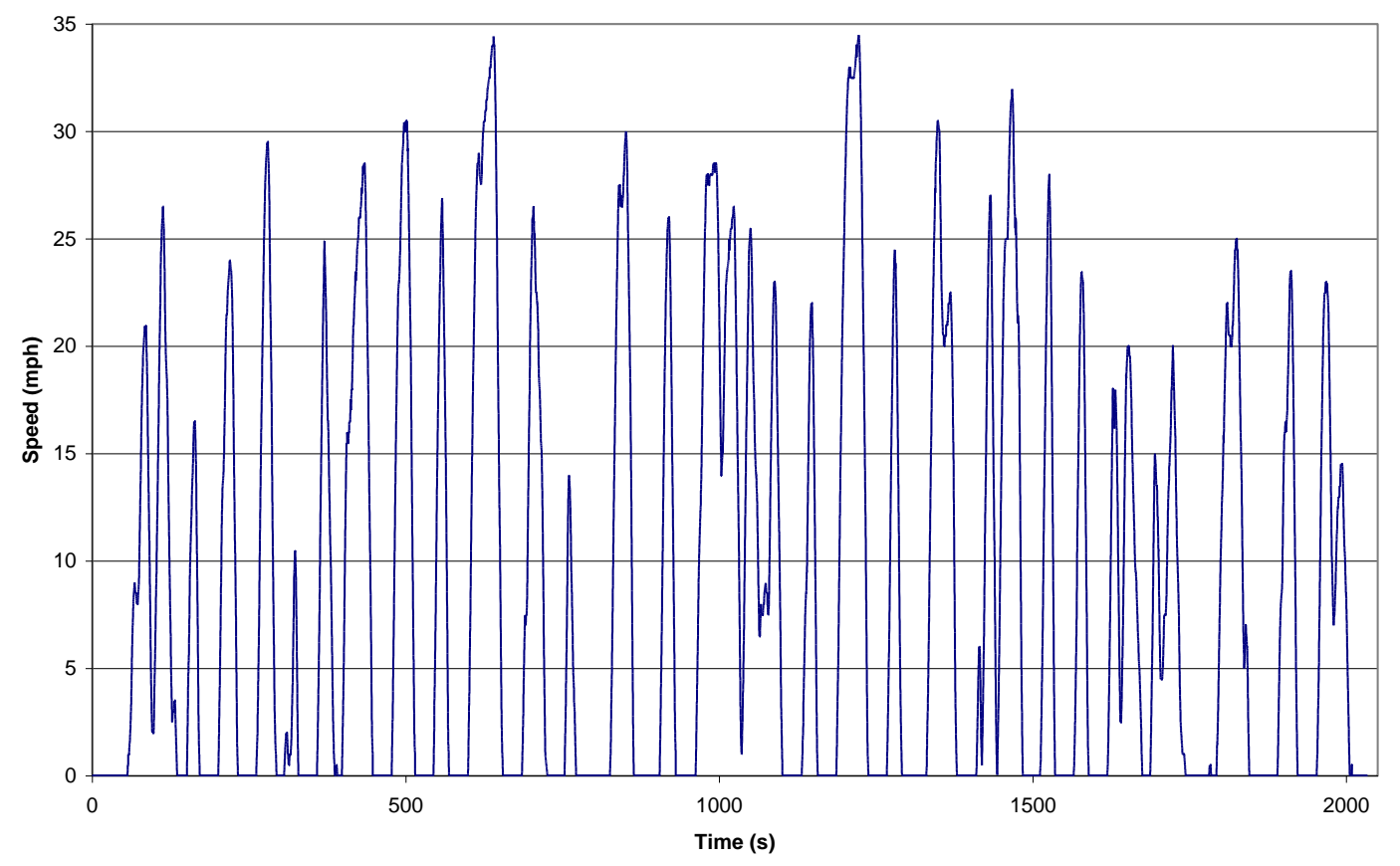

Figure 24 DDC Powered Bus with ULSD - Leg 1 of Test Route

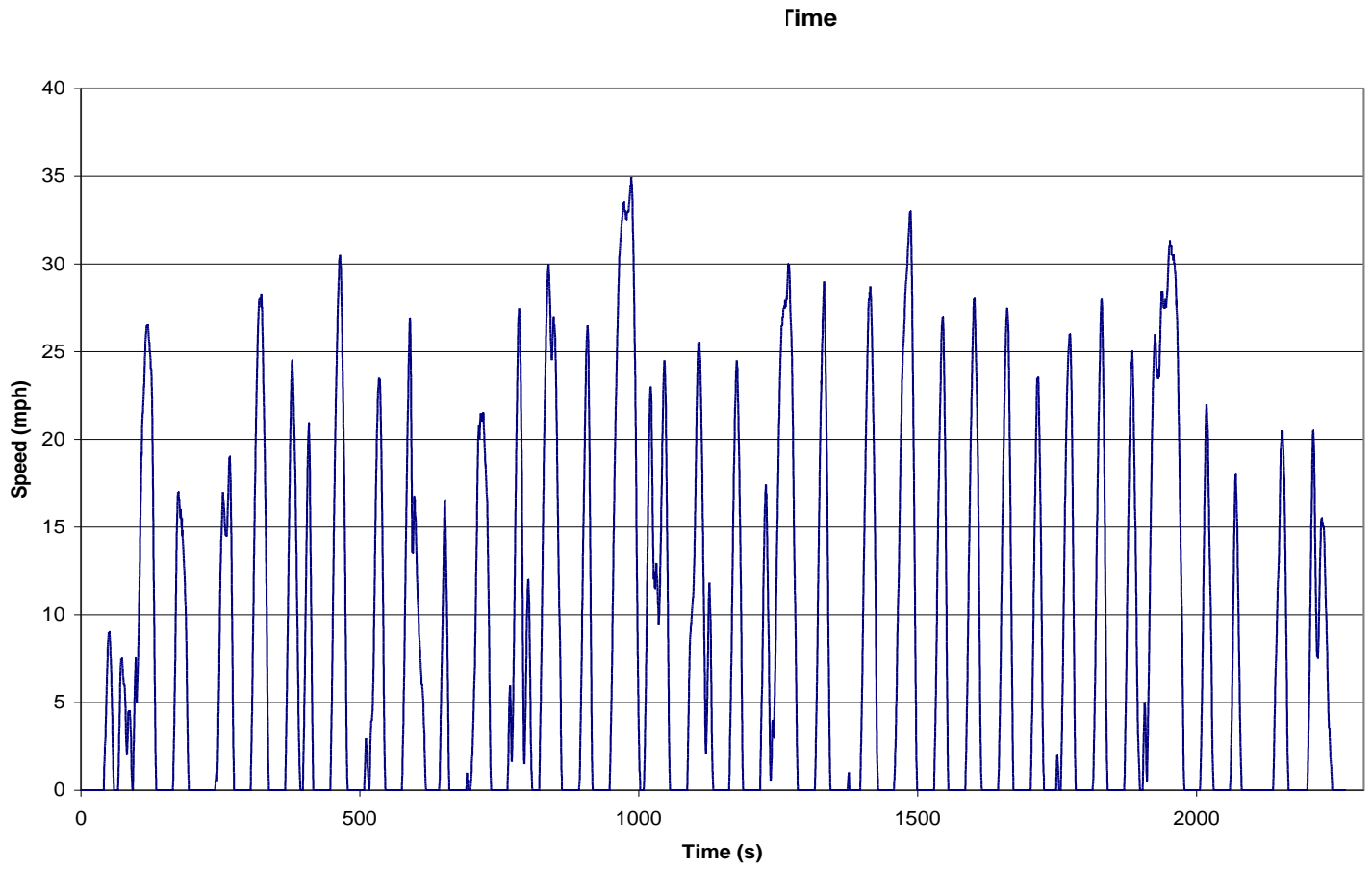

Figure 25 DDC Powered Bus with ULSD - Leg 2 of Test Route 


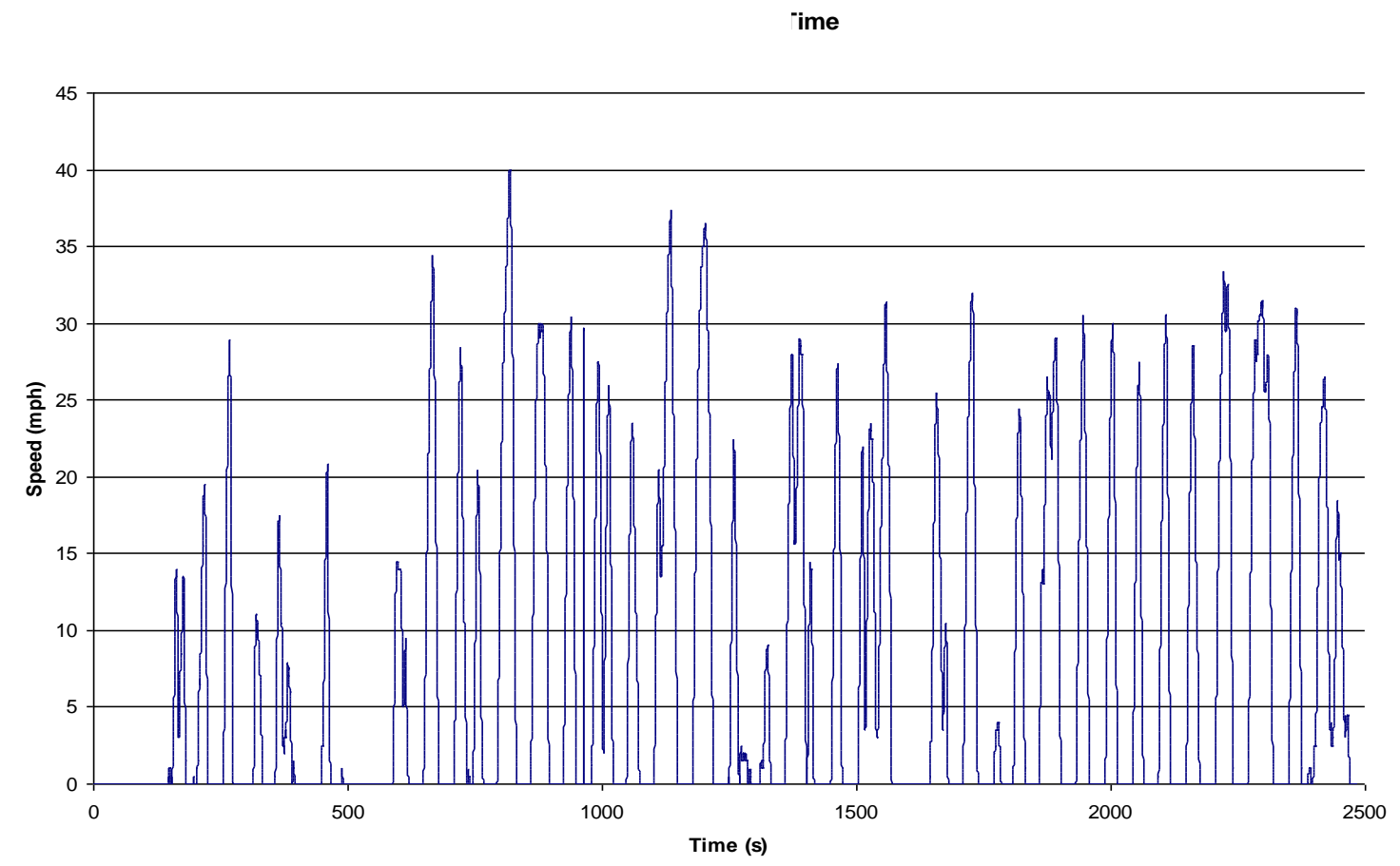

Figure 26 DDC Powered Bus with Soybean Oil B20 - Leg 1 of Test Route

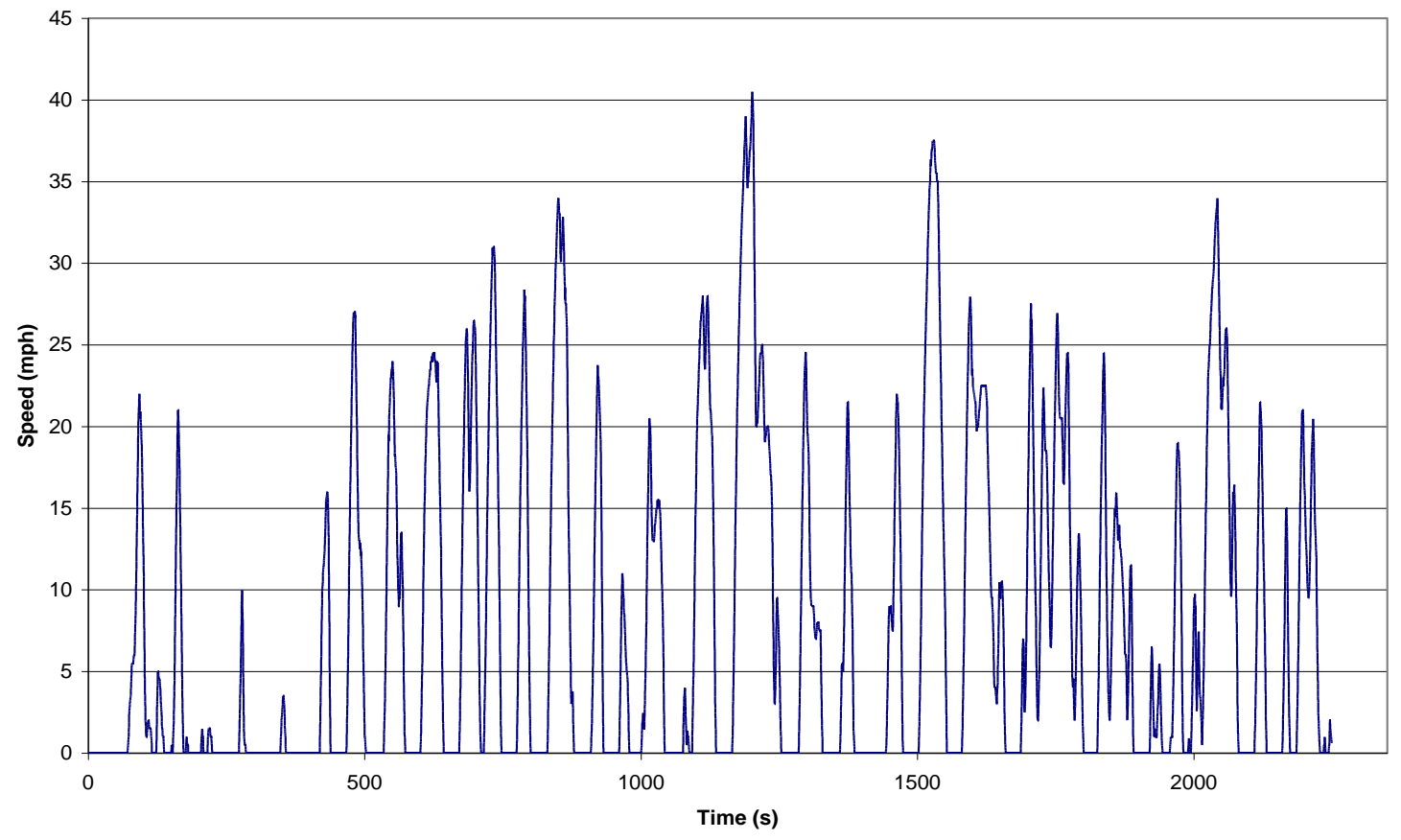

Figure 27 DDC Powered Bus with Soybean Oil B20 - Leg 2 of Test Route 




Figure 28 DDC Powered Bus with Palm Oil B20 - Leg 1 of Test Route



Figure 29 DDC Powered Bus with Palm Oil B20 - Leg 2 of Test Route 


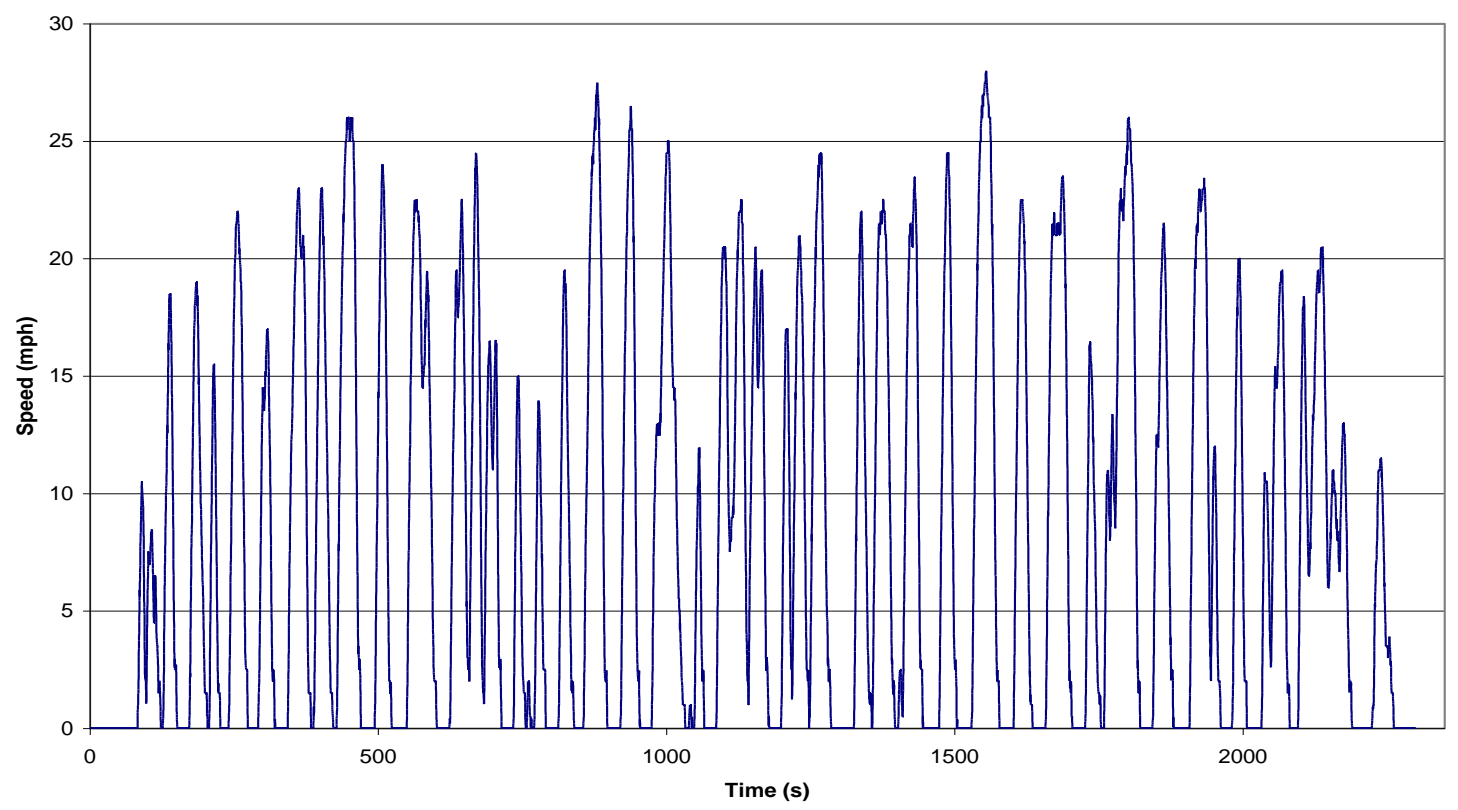

Figure 30 Cummins Powered Bus with ULSD - Leg 1 of Test Route



Figure 31 Cummins Powered Bus with ULSD - Leg 2 of Test Route 


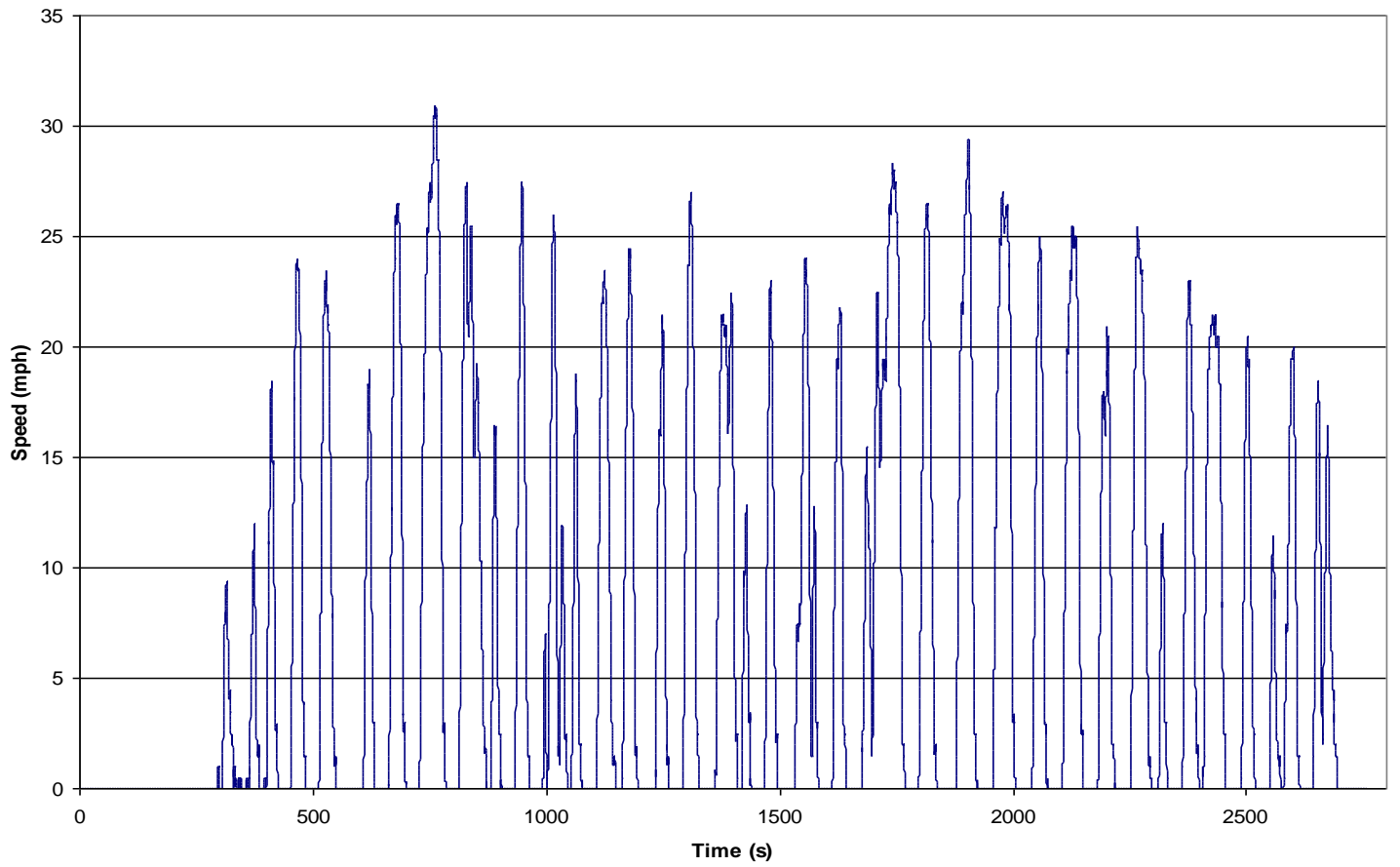

Figure 32 Cummins Powered Bus with Soybean Oil B20 - Leg 1 of Test Route

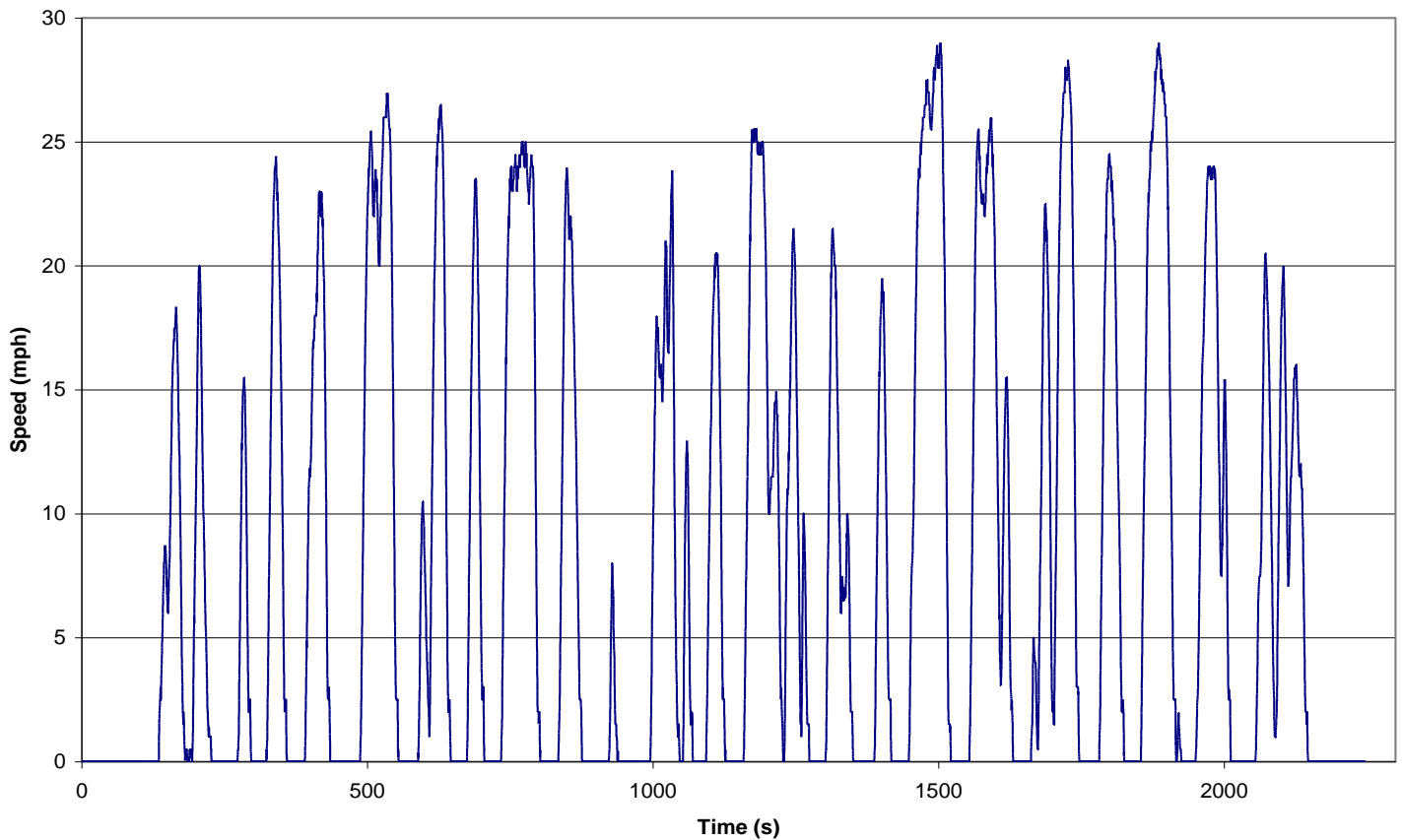

Figure 33 Cummins Powered Bus with Soybean Oil B20 - Leg 2 of Test Route 


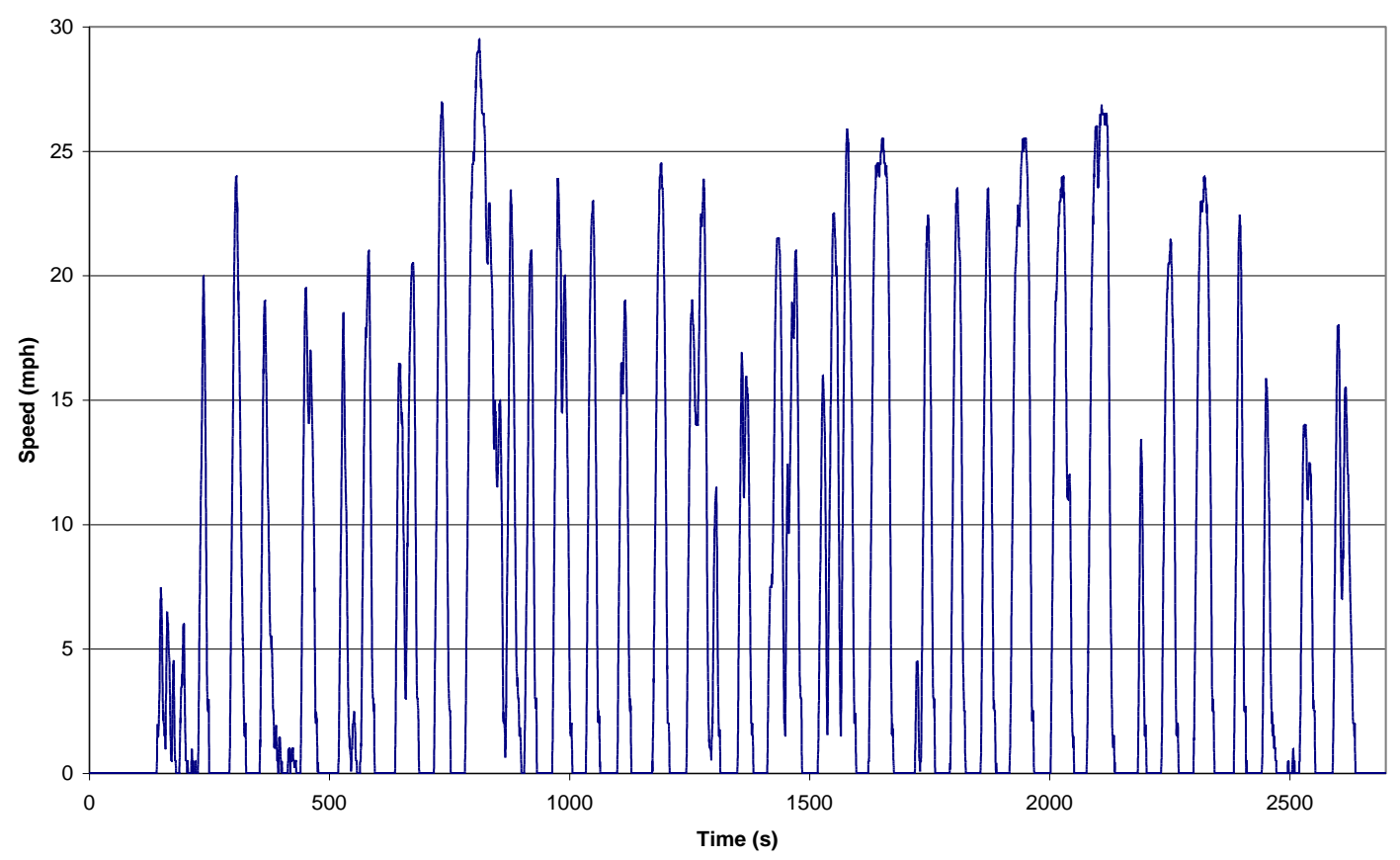

Figure 34 Cummins Powered Bus with Palm Oil B20 - Leg 1 of Test Route

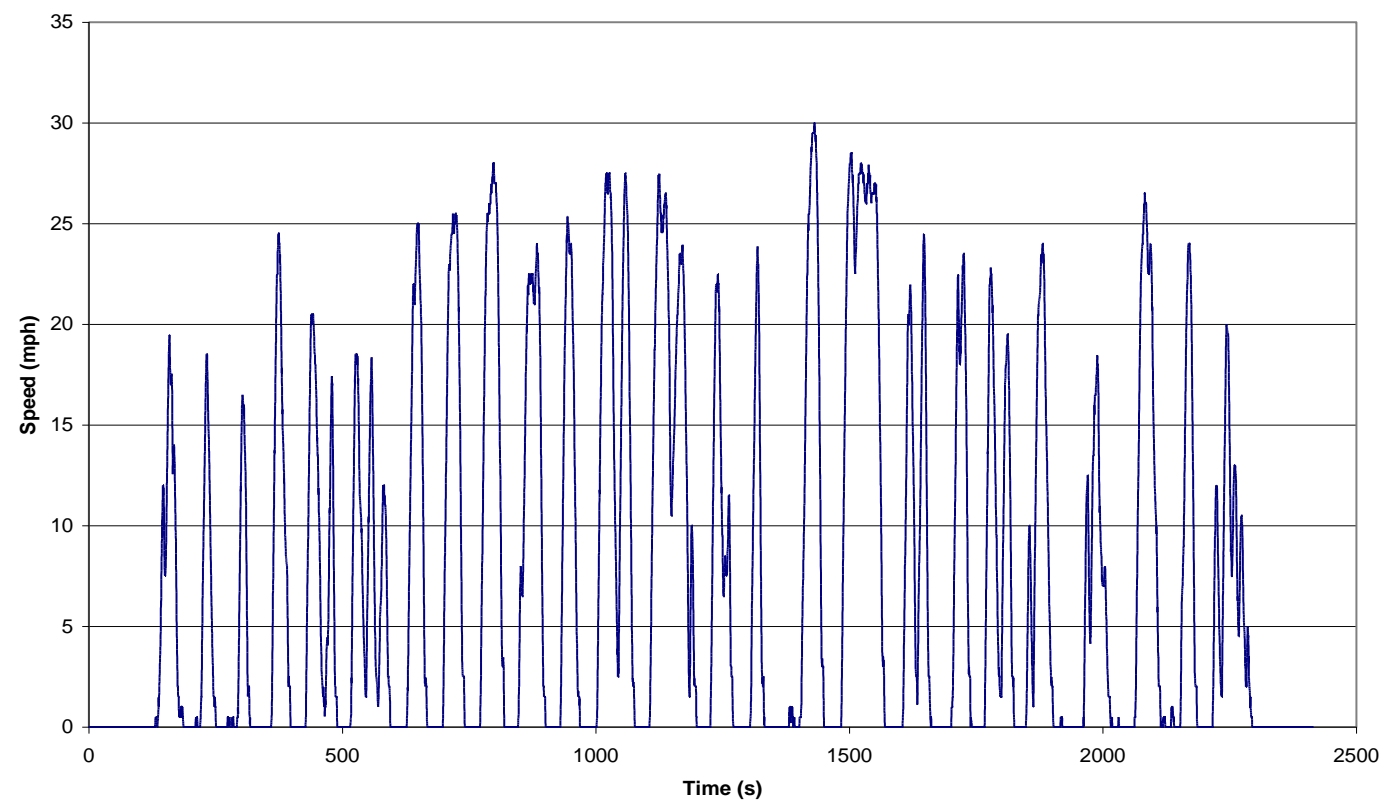

Figure 35 Cummins Powered Bus with Palm Oil B20 - Leg 2 of Test Route 


\subsubsection{Vehicle Acceleration Performance}

An acceleration analysis was also performed on the on-road data that were collected. Figure 36 through Figure 41 illustrates that, for the Cummins powered bus, slightly higher accelerations (1$2 \%$ ) were recorded for the biofuel tests versus ULSD. For the DDC powered bus, the highest recorded accelerations were obtained during the soybean oil-based biodiesel tests while the palm-based test showed no change in acceleration. Even though slight differences in measured accelerations were encountered during the on-road evaluation of the three fuels, the differences were not significant enough to impact overall vehicle performance during revenue service. Moreover, driver accounts of vehicle performance did not indicate a noticeable performance difference among the three candidate fuels.



Figure 36 On-road Acceleration Analysis Results for Bus 04208 - DDC S50 with ULSD Fuel 




Figure 37 On-road Acceleration Analysis Results for Bus 04208 - DDC S50 with Soybean Oil B20



Figure 38 On-road Acceleration Analysis Results for Bus 04208 - DDC S50 with Palm Oil B20 




Figure 39 On-road Acceleration Analysis Results for Bus 05108 - Cummins ISM with ULSD Fuel

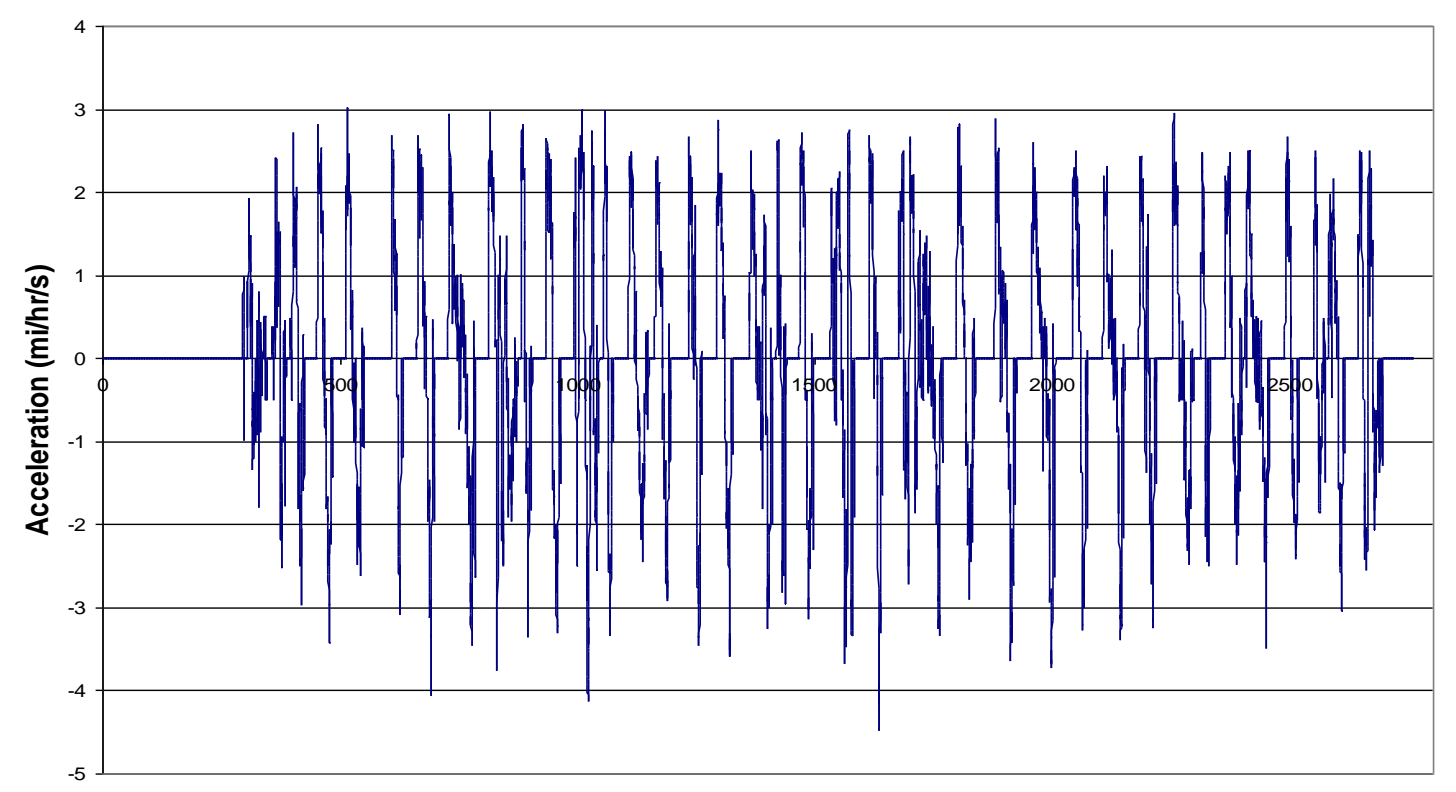

Time (s)

Figure 40 On-road Acceleration Analysis Results for Bus 05108 - Cummins ISM with Soybean Oil B20 




Figure 41 On-road Acceleration Analysis Results for Bus 05108 - Cummins ISM with Palm Oil B20

\subsubsection{Error in MEMS $\mathrm{CO}_{2}$ Measurement}

During test numbers M190057-2 and M190058-2 serial communication was lost from the $\mathrm{CO}_{2}$ analyzer. This resulted in an under estimation of $\mathrm{CO}_{2}$ produced thus creating a large percent error when compared to ECU fuel consumption. Due to the time constraint of this project these tests were not able to be re-run. Figure $42 \&$ Figure 43 shows the loss of serial communication with the $\mathrm{CO}_{2}$ analyzer. 




Figure 42 Test Number M190057-2 Loss of $\mathrm{CO}_{2}$ Serial Communication

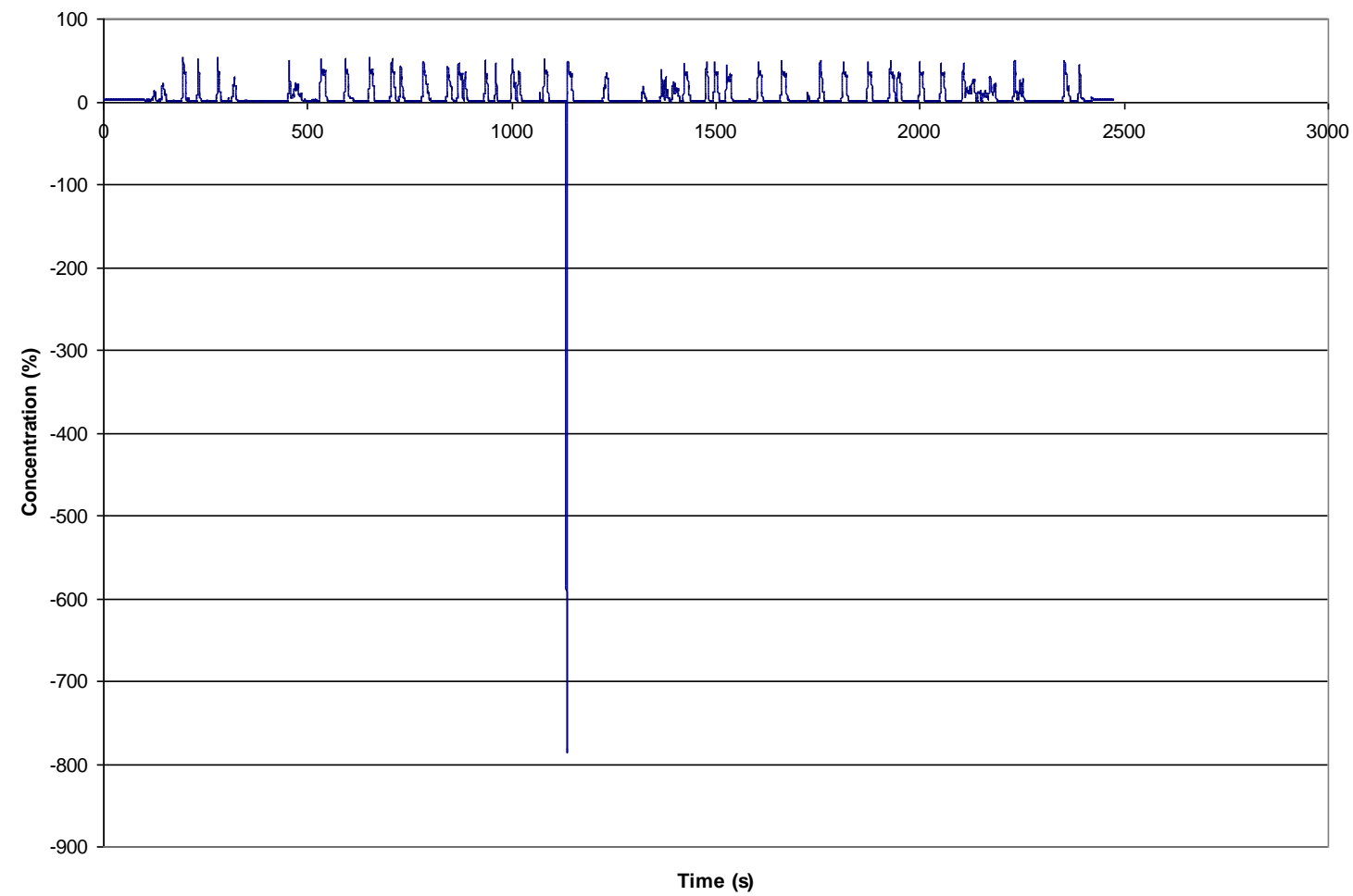

Figure 43 Test Number M190058-2 Loss of $\mathrm{CO}_{2}$ Serial Communication 


\section{CONCLUSIONS}

The use of biodiesel blends has become increasingly more popular as an alternative energy source for internal combustion compression-ignition engines. B20 blends offer cost savings, compared to their neat diesel counterparts due to government subsidies for the use of biodiesel, and generally exhibit reductions in PM, which has been long-recognized as a respiratory health hazard. Although the energy density of B20 is about 5-7\% less than that of ULSD, the improvement in combustion efficiency often translates into less of a fuel economy penalty. Blends higher than $20 \%$ are typically not employed due to an associated increase in $\mathrm{NO}_{\mathrm{x}}$ production.

The results for the two biodiesel fuels included in Table 12 \& Table 14 (DDC S50) and Table 13 \& Table 15 (Cummins ISM) are followed by parenthetical values that indicate the percentage difference when compared with the baseline value obtained from ULSD operation, for the respective parameters.

As indicated for the vehicle chassis dynamometer tests, B20 blends exhibited 5-7\% improvements in fuel economy, with similar vehicle averaged reductions in fuel consumption realized for both biodiesel blends. Oxides of nitrogen emissions measured from the tests for the DDC bus (bus 04208) were actually lower for B20 fuels than for the ULSD baseline fuel. NOx emissions recorded for the Cummins bus (bus 05108) were slightly higher for B20 biodiesel operation (2-3\%). PM was reduced by (20-30\%) for operation on both biodiesels for both vehicles, with higher reductions in PM being realized for operation with palm oil-based B20. For the in-use vehicle evaluations, both biodiesel blends exhibited slight differences in fuel economy when compared to ULSD - with an exception for the DDC bus (bus 04208) where fuel economy for the palm oil-based B20 was 20\% improved over the ULSD baseline. However, for the DDC palm oil biodiesel test, the brake-specific fuel consumption was consistent with other tests, indicating that much less work was performed by the vehicle for that particular instance of operation which was quantitatively supported by the kinetic energy analysis. 
Acceleration analysis of the chassis dynamometer tests reviled an increase in acceleration with the use of the biofuels. However these increases were not substantial enough to affect the overall performance of the vehicle, this was supported by the on-road test and driver accounts of noticing no difference in the performance of the three fuels.

Table 12 Summary of Vehicle/Fuel Performance Data from Chassis Dynamometer Tests with DDC Bus (Bus 04208)

\begin{tabular}{||l|c|c|c|c|c|c|c||}
\hline \hline DDC & \multicolumn{7}{|c||}{ Average Emissions Results are in $\mathrm{g} / \mathrm{mile}$} \\
\hline & $\mathrm{CO}$ & NOx & FIDHC & $\mathrm{PM}$ & $\mathrm{CO}_{2}$ & mile/gal & $\begin{array}{c}\text { Average } \\
\text { Acceleration } \\
\text { (mi/h/s })\end{array}$ \\
\hline ULSD & 1.35 & 16.2 & 0.24 & 0.51 & 4302 & 2.24 & 1.97 \\
\hline Soybean Oil B20 & 1.25 & 15.3 & 0.19 & 0.4 & 4258 & 2.39 & 2.02 \\
\hline Palm Oil B20 & 1.15 & 15.3 & 0.24 & 0.35 & 4208 & 2.41 & 1.95 \\
\hline \% Diff Soybean Oil B20 & -7.4 & -5.6 & -20.8 & -21.6 & -1.0 & 6.7 & 2.3 \\
\hline \% Diff Palm Oil B20 & -14.8 & -5.6 & 0.0 & -31.4 & -2.2 & 7.6 & -0.8 \\
\hline
\end{tabular}

Table 13 Summary of Vehicle/Fuel Performance Data from Chassis Dynamometer Tests with Cummins Bus (Bus 05108)

\begin{tabular}{||l|c|c|c|c|c|c|c||}
\hline \hline Cummins & \multicolumn{7}{|c||}{ Average Emissions Results are in } \\
\hline Fuel & $\mathrm{CO}$ & $\mathrm{NO}$ & $\mathrm{FIDHC}$ & $\mathrm{PM}$ & $\mathrm{CO}_{2}$ & mile/gal & $\begin{array}{c}\text { Average } \\
\text { Acceleration } \\
\text { (mi/h/s })\end{array}$ \\
\hline ULSD & 3.34 & 14.5 & 0.039 & 0.51 & 4182 & 2.31 & 1.95 \\
\hline Soybean Oil B20 & 3.05 & 14.8 & 0.043 & 0.4 & 4136 & 2.45 & 2.11 \\
\hline Palm Oil B20 & 3.00 & 14.9 & 0.041 & 0.35 & 4171 & 2.43 & 2.14 \\
\hline $\begin{array}{l}\text { \% Diff Soybean Oil } \\
\text { B20 }\end{array}$ & -8.7 & 2.1 & 10.3 & -21.6 & -1.1 & 6.1 & 8.2 \\
\hline \% Diff Palm Oil B20 & -10.2 & 2.8 & 5.1 & -31.4 & -0.3 & 5.2 & 9.6 \\
\hline \hline
\end{tabular}


Table 14 Summary of Vehicle/Fuel Performance Data from In-use Vehicle Tests with DDC Bus (Bus 04208)

\begin{tabular}{||l|c|c|c|c|c|c||}
\hline \hline DDC & \multicolumn{2}{|c|}{$\mathrm{g} / \mathrm{mile}$} & \multicolumn{2}{c|}{$\mathrm{g} / \mathrm{bhp}-\mathrm{h}$} & $\mathrm{mi} / \mathrm{gal}$ & $\mathrm{lb} / \mathrm{bhp}-\mathrm{h}$ \\
\hline Fuel & CO2 & NOx & CO2 & NOx & Fuel consumption & BSFC \\
\hline ULSD & 4155.4 & 18.4 & 498.1 & 2.2 & 2.35 & 0.345 \\
\hline Soybean Oil B20 & 3938.7 & 18.5 & 486.4 & 2.3 & 2.45 & 0.336 \\
\hline Palm Oil B20 & 3401.6 & 15.3 & 489.8 & 2.2 & 2.83 & 0.339 \\
\hline $\begin{array}{l}\text { \% Diff Soybean Oil } \\
\text { B20 }\end{array}$ & -5.2 & 0.7 & -2.4 & 3.2 & 4.3 & -2.6 \\
\hline \% Diff Palm Oil B20 & -18.1 & -16.8 & -1.7 & -0.7 & 20.7 & -1.7 \\
\hline
\end{tabular}

Table 15 Summary of Vehicle/Fuel Performance Data from In-use Vehicle Tests with Cummins Bus (Bus 05108)

\begin{tabular}{||l|c|c|c|c|c|c||}
\hline \hline Cummins & \multicolumn{2}{|c|}{$\mathrm{g} / \mathrm{mile}$} & \multicolumn{2}{c|}{$\mathrm{g} / \mathrm{bhp}-\mathrm{h}$} & $\mathrm{mi} / \mathrm{gal}$ & $\mathrm{lb} / \mathrm{bhp}-\mathrm{h}$ \\
\hline Fuel & CO2 & NOx & CO2 & NOx & $\begin{array}{c}\text { Fuel } \\
\text { consumption }\end{array}$ & BSFC \\
\hline ULSD & $\begin{array}{c}3926 . \\
1\end{array}$ & 18.2 & 497.8 & 2.3 & 2.45 & 0.345 \\
\hline Soybean Oil B20 & $\begin{array}{c}3936 . \\
0\end{array}$ & 16.2 & 495.6 & 2.0 & 2.46 & 0.343 \\
\hline Palm Oil B20 & $\begin{array}{c}4005 . \\
2\end{array}$ & 15.9 & 491.5 & 1.9 & 2.41 & 0.341 \\
\hline \% Diff Soybean Oil B20 & 0.3 & -11.1 & -0.4 & -13.4 & 0.4 & -0.4 \\
\hline \% Diff Palm Oil B20 & 2.0 & -12.7 & -1.3 & -17.7 & -1.6 & -1.2 \\
\hline
\end{tabular}




\section{RECOMMENDATIONS}

There are many things that could have been done differently to produce higher quality data over the course of this study. First of which is the gravimetric fuel measurement procedure, it was very difficult to obtain good gravimetric fuel data because of the method in which it was done. Gravimetric fuel data was collected by sliding a 55 gallon drum of fuel off a box and onto the scale. An apparatus needed to be built that would hold the drum above the scale while testing and then lower it when a measurement needed to be taken. Moreover a smaller fuel barrel should have been used for the on-road testing to make gravimetric measurements easier. Secondly a full fuel analysis needed to be completed on the mixed biodiesel fuels in order to provide more insight to the results. This should be standard operating procedure for any fuels testing that is being done. Also a fuel cooler should have been placed in line of the drum to cool returning fuel. The barrel reached high temperatures during the course of the on road tests. 


\section{REFERENCES}

1. National Biodiesel Board, "Biodiesel Basics," Web,25 Jul 2008, http://www.biodiesel.org/resources/biodiesel basics/default.shtm.

2. U.S. Environmental Protection agency, "U.S. EPA Smart Way to Grow And Go," Web, 28 July 2008, http://www.epa.gov/smartway/growandgo/documents/factsheet-biodiesel.htm.

3. Graboski, M.S., Ross, J.D., and McCormick, R.L., "Transient Emissions from No. 2 Diesel and Biodiesel Blends in a DDC Series 60 Engine," 961166, SAE International, Warrendale, Pennsylvania, USA, 1996.

4. Suryawanshi, J. G., "Performance and Emission Characteristics of CI Engine Fueled by Coconut Oil Methyl Ester," 2006-32-0077, SAE International, Warrendale, Pennsylvania, USA, 2006.

5. Payri, F., Macián, V., Arrègle, J., Tormos, B., and MartÍnez, J.L., "Heavy-Duty Diesel Engine Performance and Emission Measurements for Biodiesel (From Cooking Oil) Blends Used in the ECOBUS Project," 2005-01-2205, SAE International, Warrendale, Pennsylvania, USA, 2005.

6. Fang, H. L., Whitacre, S.D., Yamaguchi, E.S., and Boons, M., "Biodiesel Impact on Wear Protection of Engine Oils," 2007-01-4141, SAE International, Warrendale, Pennsylvania, USA, 2007.

7. Sem, T.R., "Effect of various lubricating oils on piston deposits in biodiesel-fueled engines," 2004-01-0098, SAE International, Warrendale, Pennsylvania, USA, 2004.

8. McKain, D.L., Atkinson, R.J., Clarke, N.N., Mucino, V.H., Figueroa, J.V.H.P., Villasenor, S.Z.H., Hernandez, C.F.G., Borrel, E.R., Maximo, R.P., and Cervantes, D.L., "Development of a Driving Schedule to Mimic Transit Bus Behavior in Mexico City," 2006-01-3394, SAE International, Warrendale, Pennsylvania, USA, 2006.

9. Wysor, T., and France, C., "Selection of Transit Cycles for Heavy-Duty Vehicles," PB294 221, U.S. Environmental Protection Agency, 1978.

10. Tompkins, B T., Esquivel, J., ad Jacobs, T.J., "Performance Parameter Analysis of a Biodiesel-Fuelled Medium Duty Engine" 2009-01-0481, SAE International, Warrendale, Pennsylvania, USA, 2009.

11. Suryawanshi, J.G., and Deshpanda, N.V., "Overview of EGR, Injection Timing and Pressure on Emissions and Performance of CI Engine with Pongamia Methyl Ester," 2005-26-346, SAE International, Warrendale, Pennsylvania, USA, 2005.

12. Nuszkowski, J., Tincher, R R., and Thompson, G J,. "Evaluation of the $\mathrm{NO}_{\mathrm{x}}$ Emissions from Heavy-Duty Diesel Engines with the Addition of Cetane Improvers," JAUTO1114, Proc. IMech. Vol.223 Part. D : J. Automobile Engineering. 
13. Ryan III, T., Buckingham, L., Dodge, L., and Olikara, C. "The Effects of Fuel Properties on Emissions From a 2.5gm NO $\mathrm{g}_{\mathrm{X}}$ Heavy-Duty Diesel Engine," 982491, SAE International, Warrendale, Pennsylvania, USA, 1998.

14. "Control of Air Pollution from new motor vehicles: Proposed Heavy-Duty Engine and Vehicle Standards and Highway Diesel Fuel Sulfur Control Requirements", EPA, 40 CFR Parts 69, 80 and 86, June 2, 2000.

15. Meriam Accutube Flow Handbook, 1984, Meriam Instrument., 10920 Madison Avenue, Cleveland, $\mathrm{OH}$.

16. Gautam, M., Clark, N. N., Thompson, G. J., and Lyons, D. W., "Assessment of Mobile Monitoring Technologies for Heavy-Duty Vehicle Emissions," White paper Submitted to the Settling Heavy-Duty Diesel Engine Manufacturers, Department of Mechanical and Aerospace Engineering, West Virginia University, Morgantown, WV, 1999.

17. U.S. Enviromental Protection Agency "Concent Decrees," 1998, Web, 29 Jul 2009, http://www.epa.gov/compliance/resources/decrees/civil/caa/detroitcd.pdf.

18. Horiba Instruments, "Automotive test systems," Web, 25 Jul 2008, http://www.emd.horiba.com/engmeas/be140ad.

19. SwRI Final Letter Report, "Heavy-Duty Diesel Engine NO, and PM Correction Factors,” SwRI Project 08-2597, July 1999.

20. Bolyard J., "Evaluation of an Air to Fuel Ratio derived Exhaust Flow For In-Use Emissions Testing," M.S. Thesis. West Virginia University. 2006.

21. Brettschneider, J., "Berechnung des Luftverhältnisses $\lambda$ von Luft-Kraftstoff-Gemischen und des Einflusses von MeBfehlern auf $\lambda$," Bosch Technische Berichte vol. 6 No.4, Germany, 1979.

22. Chang D.Y., and Van Gerpen J.H., "Determination of particulate and unburned hydrocarbon emissions from diesel engines fueled with biodiesel," 982527, SAE International, Warrendale, Pennsylvania, USA, 1998.

23. Krishnamurthy, M., and Gautam, M., "Quality Assurance of Exhaust Emissions Test Data Measured Using Portable Emissions Measurement System" 2005-01-3799, SAE International, Warrendale, Pennsylvania, USA, 2005.

24. "Standard Outline Dimensional Drawing for Annubar Primary Flow Element," Drawing No. C-3602, Dietrich Standard, Boulder, CO, 1999. 
Appendix A. Summary Short Reports of Chassis

Dynamometer Tests 
Test Sequence Number: 5310

WVU Test Reference Number: MDT-04208-Soybean Oil Based Biodiesel -MiamiD

$\begin{array}{ll}\text { Fleet Owner Full Name } & \text { Miami Dade Transit } \\ \text { Fleet Address } & 3300 \text { Northwest 32 Ave. } \\ \text { Fleet Address (City, State, Zip) } & \text { Miami FL 33142 } \\ & \\ \text { Vehicle Type } & \text { Transit Bus } \\ \text { Vehicle ID Number (VIN) } & 1 \text { N90401784A140216 } \\ \text { Vehicle Manufacturer } & \text { North American Bus Indust } \\ \text { Vehicle Model Year } & 2004 \\ \text { Gross Vehicle Weight (GVW) (Ib.) } & 42540 \\ \text { Vehicle Total Curb Weight (Ib.) } & 29840 \\ \text { Vehicle Tested Weight (Ib.) } & 35700 \\ \text { Odometer Reading (mile) } & 191800 \\ \text { Transmission Type } & \text { Auto } \\ \text { Transmission Configuration } & 5 \text { speed } \\ \text { Number of Axles } & 2 \\ \text { Engine Type } & \text { Detroit Diesel S-50 } \\ \text { Engine ID Number } & 6047 \mathrm{MKLE} \\ \text { Engine Model Year } & 2004 \\ \text { Engine Displacement (Liter) } & 8.5 \\ \text { Number of Cylinders } & 6 \\ \text { Engine Rated Power (hp) } & 275 \\ \text { Primary Fuel } & \\ \text { Particulate Trap Manufacturer } & \text { Soybean oil Based Biodiesel } \\ \text { Catalytic Converter Manufacturer } & \text { Done } \\ \text { Test Cycle } & \text { MiamiD } \\ \text { Test Date } & 4 / 17 / 08 \\ \text { Engineer } & \\ \text { Driver } & \text { Sindler, Petr } \\ & \text { England, Gary } \\ & \end{array}$

Emissions Results (g/mile)
\begin{tabular}{|c|c|c|c|c|c|c||c|c|c|}
\hline Run Seq. No. & $\mathrm{CO}$ & $\mathrm{NO}_{\mathrm{x}}{ }^{1}$ & $\mathrm{NO}_{\mathrm{x}}{ }^{2}$ & $\mathrm{FIDHC}$ & $\mathrm{PM}$ & $\mathrm{CO}_{2}$ & $\mathrm{mile} / \mathrm{gal}$ & $\mathrm{BTU} / \mathrm{mile}$ & Miles \\
\hline $5310-3$ & 2.94 & 13.50 & 15.09 & 0.042 & 1.69 & 4116 & 2.47 & 51890 & 2.59 \\
\hline $5310-4$ & 3.15 & 12.66 & 14.27 & 0.063 & 1.69 & 4187 & 2.42 & 52786 & 2.60 \\
\hline $5310-5$ & 3.06 & 13.26 & 14.91 & 0.025 & 1.69 & 4106 & 2.47 & 51762 & 2.60 \\
\hline & & & & & & & & & \\
\hline 5310 Average & 3.05 & 13.1 & 14.8 & 0.043 & 1.69 & 4136 & 2.45 & 52146 & 2.60 \\
\hline Std. Dev. & 0.10 & 0.4 & 0.4 & 0.019 & 0.00 & 44 & 0.03 & 558 & 0.01 \\
\hline CV\% & 3.4 & 3.3 & 2.7 & 43.1 & 0.2 & 1.1 & 1.1 & 1.1 & 0.2 \\
\hline
\end{tabular}

x-Not Reportable, a-Outlier, b-HC Not Reportable(Residual HC), c-missing component, d-Coefficient of Variation Too Large, ebelow detectable limit

Special Procedures:

B20 (soybean oil-based) 
Test Sequence Number: 5313

WVU Test Reference Number: MDT-04208-Palm Oil Based Biodiesel -MiamiD

$\begin{array}{ll}\text { Fleet Owner Full Name } & \text { Miami Dade Transit Agency } \\ \text { Fleet Address } & 3300 \text { Northwest 32 Ave. } \\ \text { Fleet Address (City, State, Zip) } & \text { Miami FL 33142 } \\ & \\ \text { Vehicle Type } & \text { Transit Bus } \\ \text { Vehicle ID Number (VIN) } & \text { N90401784A140216 } \\ \text { Vehicle Manufacturer } & \text { North American Bus Indust } \\ \text { Vehicle Model Year } & 2004 \\ \text { Gross Vehicle Weight (GVW) (Ib.) } & 42540 \\ \text { Vehicle Total Curb Weight (Ib.) } & 29840 \\ \text { Vehicle Tested Weight (Ib.) } & 35700 \\ \text { Odometer Reading (mile) } & 191800 \\ \text { Transmission Type } & \text { Auto } \\ \text { Transmission Configuration } & 5 \text { speed } \\ \text { Number of Axles } & 2 \\ \text { Engine Type } & \text { Detroit Diesel S-50 } \\ \text { Engine ID Number } & 6047 \mathrm{MKLE} \\ \text { Engine Model Year } & 2004 \\ \text { Engine Displacement (Liter) } & 8.5 \\ \text { Number of Cylinders } & 6 \\ \text { Engine Rated Power (hp) } & 275 \\ & \\ \text { Primary Fuel } & \text { Palm oil Based Biodiesel } \\ \text { Particulate Trap Manufacturer } & \text { none } \\ \text { Catalytic Converter Manufacturer } & \text { Nelson } \\ \text { Test Cycle } & \text { MiamiD } \\ \text { Test Date } & 4 / 18 / 08 \\ & \\ \text { Engineer } & \text { Sindler, Petr } \\ \text { Driver } & \text { England, Gary } \\ & \end{array}$

Emissions Results (g/mile)

Fuel Economy

\begin{tabular}{|c|c|c|c|c|c|c||c|c|c|}
\hline Run Seq. No. & $\mathrm{CO}$ & $\mathrm{NOx}^{1}$ & $\mathrm{NO}^{2}$ & $\mathrm{FIDHC}$ & $\mathrm{PM}$ & $\mathrm{CO}_{2}$ & mile/gal & BTU/mile & Miles \\
\hline $5313-2$ & 3.09 & 14.72 & 14.74 & 0.044 & 1.55 & 4166 & 2.44 & 52522 & 2.59 \\
\hline $5313-3$ & 2.71 & 13.50 & 15.01 & 0.049 & 1.56 & 4188 & 2.42 & 52792 & 2.55 \\
\hline $5313-4$ & 3.10 & 13.30 & 14.96 & 0.030 & 1.65 & 4159 & 2.44 & 52440 & 2.60 \\
\hline & & & & & & & & & \\
\hline 5313 Average & 2.97 & 13.8 & 14.9 & 0.041 & 1.59 & 4171 & 2.43 & 52585 & 2.58 \\
\hline Std. Dev. & 0.23 & & 0.1 & 0.010 & 0.06 & 15 & 0.01 & 184 & 0.03 \\
\hline CV\% & 7.6 & & 0.6 & 24.9 & 3.6 & 0.4 & 0.3 & 0.3 & 1.2 \\
\hline
\end{tabular}

x-Not Reportable, a-Outlier, b-HC Not Reportable(Residual HC), c-missing component, d-Coefficient of Variation Too Large, ebelow detectable limit

* CV\% and Std. Dev. was not calculated for $\mathrm{NO}_{\mathrm{X}}{ }^{1}$ because tests 3 and 4 were run in $\mathrm{NO} / \mathrm{NO}_{\mathrm{X}}$ split mode 
Test Sequence Number: 5315

WVU Test Reference Number: MDT-04208- ULSD -MiamiD

\author{
Fleet Owner Full Name \\ Miami Dade Transit Agency \\ Fleet Address \\ Fleet Address (City, State, Zip) \\ 3300 Northwest 32 Ave. \\ Miami FL 33142 \\ Vehicle Type \\ Vehicle ID Number (VIN) \\ Vehicle Manufacturer \\ Vehicle Model Year \\ Transit Bus \\ 1N90401784A140216 \\ North American Bus Indust \\ Gross Vehicle Weight (GVW) (Ib.) 42540 \\ Vehicle Total Curb Weight (Ib.) 29840 \\ Vehicle Tested Weight (Ib.) 35700 \\ Odometer Reading (mile) 191800 \\ Transmission Type Auto \\ Transmission Configuration 5 speed \\ Number of Axles 2 \\ Engine Type \\ Engine ID Number \\ Engine Model Year \\ Detroit Diesel S-50 \\ 6047MKLE \\ 2004 \\ $\begin{array}{ll}\text { Engine Displacement (Liter) } & 8.5 \\ \text { Number of Cylinders } & 6 \\ \text { Engine Rated Power (hp) } & 275\end{array}$ \\ Primary Fuel ULSD \\ Particulate Trap Manufacturer none \\ Catalytic Converter Manufacturer Nelson \\ Test Cycle MiamiD \\ Test Date 4/18/08 \\ Engineer Sindler, Petr \\ Driver England, Gary
}

Emissions Results (g/mile) $\quad$ Fuel Economy

\begin{tabular}{|c|c|c|c|c|c|c|c|c|c|}
\hline Run Seq. No. & $\mathrm{CO}$ & $\mathrm{NO}^{1}$ & $\mathrm{NO}^{2}$ & FIDHC & PM & $\mathrm{CO}_{2}$ & mile/gal & BTU/mile & Miles \\
\hline $5315-2$ & 3.33 & 14.50 & 14.54 & 0.041 & 2.32 & 4169 & 2.31 & 55296 & 2.60 \\
\hline $5315-4$ & 3.35 & 12.74 & 14.16 & 0.045 & 2.27 & 4095 & 2.35 & 54316 & 2.60 \\
\hline $5315-5$ & 3.32 & 12.97 & 14.81 & 0.032 & 2.34 & 4282 & 2.25 & 56784 & 2.60 \\
\hline 5315 Average & 3.34 & 13.4 & 14.5 & 0.039 & 2.31 & 4182 & 2.31 & 55465 & 2.60 \\
\hline Std. Dev. & 0.01 & & 0.3 & 0.007 & 0.03 & 94 & 0.05 & 1243 & 0.00 \\
\hline CV\% & 0.4 & & 2.0 & 17.4 & 1.4 & 2.2 & 2.2 & 2.2 & 0.1 \\
\hline
\end{tabular}

x-Not Reportable, a-Outlier, b-HC Not Reportable(Residual HC), c-missing component, d-Coefficient of Variation Too Large, ebelow detectable limit

* CV\% and Std. Dev. was not calculated for $\mathrm{NO}_{\mathrm{X}}{ }^{1}$ because tests 4 and 5 were run in $\mathrm{NO} / \mathrm{NO}_{\mathrm{X}}$ split mode

Special Procedures:

ulsd, runs1,2,3 NOx mode, runs 4,5 NO/NOx split

Observations:

run 4 started late, run 5 restarted 
Test Sequence Number: 5320

WVU Test Reference Number: MDT-05108- ULSD -MiamiD

\author{
Fleet Owner Full Name \\ Miami Dade Transit Agency \\ Fleet Address \\ Fleet Address (City, State, Zip) \\ 3300 Northwest 32 Ave. \\ Miami FL 33142 \\ Vehicle Type \\ Vehicle ID Number (VIN) \\ Vehicle Manufacturer \\ Vehicle Model Year \\ Transit Bus \\ 1N90401765A140345 \\ North American Bus Indust \\ Gross Vehicle Weight (GVW) (Ib.) 42550 \\ Vehicle Total Curb Weight (Ib.) 29600 \\ Vehicle Tested Weight (lb.) 35700 \\ Odometer Reading (mile) 152114 \\ Transmission Type Auto \\ Transmission Configuration 5 speed \\ Number of Axles 2 \\ Engine Type \\ Engine ID Number \\ Engine Model Year \\ Cummins ISM 280 \\ 35130187 \\ 2005 \\ $\begin{array}{ll}\text { Engine Displacement (Liter) } & 10.8 \\ \text { Number of Cylinders } & 6 \\ \text { Engine Rated Power (hp) } & 280\end{array}$ \\ Primary Fuel ULSD \\ Particulate Trap Manufacturer none \\ Catalytic Converter Manufacturer Nelson \\ Test Cycle MiamiD \\ Test Date 4/19/08 \\ Engineer Sindler, Petr \\ Driver England, Gary
}

Emissions Results (g/mile) $\quad$ Fuel Economy

\begin{tabular}{|c|c|c|c|c|c|c|c|c|c|}
\hline Run Seq. No. & $\mathrm{CO}$ & $\mathrm{NO}^{1}$ & $\mathrm{NO}^{2}$ & FIDHC & PM & $\mathrm{CO}_{2}$ & mile/gal & BTU/mile & Miles \\
\hline $5320-4$ & 1.23 & 16.25 & 16.29 & 0.21 & 0.46 & 4347 & 2.22 & 57609 & 2.62 \\
\hline $5320-6$ & 1.46 & 15.31 & 16.10 & 0.22 & 0.49 & 4285 & 2.25 & 56792 & 2.63 \\
\hline $5320-7$ & 1.36 & 15.38 & 16.09 & 0.30 & 0.59 & 4275 & 2.26 & 56662 & 2.64 \\
\hline 5320 Average & 1.35 & 15.6 & 16.2 & 0.24 & 0.51 & 4302 & 2.24 & 57021 & 2.63 \\
\hline Std. Dev. & 0.12 & & 0.1 & 0.05 & 0.06 & 39 & 0.02 & 513 & 0.01 \\
\hline CV\% & 8.7 & & 0.6 & 19.5 & 12.5 & 0.9 & 0.9 & 0.9 & 0.3 \\
\hline
\end{tabular}

x-Not Reportable, a-Outlier, b-HC Not Reportable(Residual HC), c-missing component, d-Coefficient of Variation Too Large, ebelow detectable limit

* CV\% and Std. Dev. was not calculated for $\mathrm{NO}_{\mathrm{X}}{ }^{1}$ because tests 6 and 7 were run in $\mathrm{NO} / \mathrm{NO}_{\mathrm{X}}$ split mode

Special Procedures:

ULSD fuel

\title{
Observations:
}

Blower was not at full flow on run 3 
Test Sequence Number: 5321

WVU Test Reference Number: MDT-05108-Soybean Oil Based Biodiesel -MiamiD

$\begin{array}{ll}\text { Fleet Owner Full Name } & \text { Miami Dade Transit Agency } \\ \text { Fleet Address } & 3300 \text { Northwest 32 Ave. } \\ \text { Fleet Address (City, State, Zip) } & \text { Miami FL 33142 } \\ & \\ \text { Vehicle Type } & \text { Transit Bus } \\ \text { Vehicle ID Number (VIN) } & 1 \text { N90401765A140345 } \\ \text { Vehicle Manufacturer } & \text { North American Bus Indust } \\ \text { Vehicle Model Year } & 2005 \\ \text { Gross Vehicle Weight (GVW) (Ib.) } & 42550 \\ \text { Vehicle Total Curb Weight (Ib.) } & 29600 \\ \text { Vehicle Tested Weight (Ib.) } & 35700 \\ \text { Odometer Reading (mile) } & 152100 \\ \text { Transmission Type } & \text { Auto } \\ \text { Transmission Configuration } & 5 \text { speed } \\ \text { Number of Axles } & 2 \\ \text { Engine Type } & \text { Cummins ISM 280 } \\ \text { Engine ID Number } & 35130187 \\ \text { Engine Model Year } & 2005 \\ \text { Engine Displacement (Liter) } & 10.8 \\ \text { Number of Cylinders } & 6 \\ \text { Engine Rated Power (hp) } & 280 \\ \text { Primary Fuel } & \\ \text { Particulate Trap Manufacturer } & \text { Soybean oil Based Biodiesel } \\ \text { Catalytic Converter Manufacturer } & \text { nene } \\ \text { Test Cycle } & \text { MiamiD } \\ \text { Test Date } & 4 / 19 / 08 \\ \text { Engineer } & \\ \text { Driver } & \text { Sindler, Petr } \\ & \text { England, Gary } \\ & \end{array}$

Emissions Results (g/mile)

Fuel Economy

\begin{tabular}{|c|c|c|c|c|c|c||c|c|c|}
\hline Run Seq. No. & $\mathrm{CO}$ & $\mathrm{NO}^{1}$ & $\mathrm{NO}^{2}$ & $\mathrm{FIDHC}$ & $\mathrm{PM}$ & $\mathrm{CO}_{2}$ & $\mathrm{mile} / \mathrm{gal}$ & $\mathrm{BTU} / \mathrm{mile}$ & Miles \\
\hline $5321-1$ & 1.28 & 15.18 & 15.20 & 0.21 & 0.41 & 4211 & 2.41 & 53064 & 2.63 \\
\hline $5321-2$ & 1.26 & 14.91 & 15.59 & 0.17 & 0.37 & 4288 & 2.37 & 54027 & 2.61 \\
\hline $5321-3$ & 1.20 & 14.49 & 15.19 & 0.19 & 0.43 & 4276 & 2.38 & 53871 & 2.63 \\
\hline & & & & & & & & & \\
\hline 5321 Average & 1.25 & 14.9 & 15.3 & 0.19 & 0.40 & 4258 & 2.39 & 53654 & 2.62 \\
\hline Std. Dev. & 0.04 & & 0.2 & 0.02 & 0.03 & 41 & 0.02 & 517 & 0.01 \\
\hline CV\% & 3.5 & & 1.3 & 11.1 & 7.0 & 1.0 & 1.0 & 1.0 & 0.5 \\
\hline
\end{tabular}

x-Not Reportable, a-Outlier, b-HC Not Reportable(Residual HC), c-missing component, d-Coefficient of Variation Too Large, ebelow detectable limit

* CV\% and Std. Dev. was not calculated for $\mathrm{NO}_{\mathrm{X}}{ }^{1}$ because tests 2 and 3 were run in $\mathrm{NO} / \mathrm{NO}_{\mathrm{X}}$ split mode 
Test Sequence Number: 5324

WVU Test Reference Number: MDT-05108- Palm Oil Based Biodiesel -MiamiD

\author{
Fleet Owner Full Name \\ Miami Dade Transit Agency \\ Fleet Address \\ Fleet Address (City, State, Zip) \\ 3300 Northwest 32 Ave. \\ Miami FL 33142 \\ Vehicle Type \\ Vehicle ID Number (VIN) \\ Vehicle Manufacturer \\ Vehicle Model Year \\ Transit Bus \\ 1N90401765A140345 \\ North American Bus Indust \\ Gross Vehicle Weight (GVW) (Ib.) 42550 \\ Vehicle Total Curb Weight (Ib.) 29600 \\ Vehicle Tested Weight (Ib.) 35700 \\ Odometer Reading (mile) \\ Transmission Type \\ Transmission Configuration \\ Number of Axles \\ Auto \\ 5 speed \\ 2 \\ Engine Type \\ Engine ID Number \\ Engine Model Year \\ Cummins ISM 280 \\ 35130187 \\ 2005 \\ $\begin{array}{ll}\text { Engine Displacement (Liter) } & 10.8 \\ \text { Number of Cylinders } & 6\end{array}$ \\ Engine Rated Power (hp) 280 \\ Primary Fuel \\ Particulate Trap Manufacturer \\ Palm oil Based Biodiesel \\ none \\ Nelson \\ MiamiD \\ Test Cycle \\ $4 / 19 / 08$ \\ Engineer \\ Sindler, Petr \\ Driver \\ England, Gary
}

Emissions Results (g/mile)

Fuel Economy

\begin{tabular}{|c|c|c|c|c|c|c|c|c|c|}
\hline Run Seq. No. & $\mathrm{CO}$ & $\mathrm{NO}^{1}$ & $\mathrm{NO}^{2}$ & FIDHC & PM & $\mathrm{CO}_{2}$ & mile/gal & BTU/mile & Miles \\
\hline $5324-1$ & 1.20 & 15.68 & 15.73 & 0.31 & 0.38 & 4294 & 2.37 & 54106 & 2.64 \\
\hline $5324-2$ & 1.21 & 15.32 & 15.39 & 0.16 & 0.33 & 4197 & 2.42 & 52886 & 2.62 \\
\hline 5324-3 & 1.08 & 14.42 & 15.08 & 0.21 & 0.33 & 4181 & 2.43 & 52682 & 2.64 \\
\hline $5324-4$ & 1.11 & 14.46 & 15.03 & 0.26 & 0.36 & 4160 & 2.44 & 52418 & 2.63 \\
\hline 5324 Average & 1.15 & 15.0 & 15.3 & 0.24 & 0.35 & 4208 & 2.41 & 53023 & 2.63 \\
\hline Std. Dev. & 0.06 & & 0.3 & 0.06 & 0.02 & 59 & 0.03 & 747 & 0.01 \\
\hline $\mathrm{CV} \%$ & 5.5 & & 1.9 & 27.5 & 6.4 & 1.4 & 1.4 & 1.4 & 0.3 \\
\hline
\end{tabular}

x-Not Reportable, a-Outlier, b-HC Not Reportable(Residual HC), c-missing component, d-Coefficient of Variation Too Large, ebelow detectable limit

* $\mathrm{CV} \%$ and Std. Dev. was not calculated for $\mathrm{NO}_{\mathrm{X}}{ }^{1}$ because tests 3 and 4 were run in $\mathrm{NO} / \mathrm{NO}_{\mathrm{X}}$ split mode 
Appendix B. Summary Short Reports of Chassis Dynamometer Acceleration Performance Tests 
Test Sequence Number: 5307

WVU Test Reference Number: MDT-04208- Soybean oil Based Biodiesel -MiamiD

$\begin{array}{ll}\text { Fleet Owner Full Name } & \text { Miami Dade Transit Agency } \\ \text { Fleet Address } & 3300 \text { Northwest 32 Ave. } \\ \text { Fleet Address (City, State, Zip) } & \text { Miami FL 33142 } \\ & \\ \text { Vehicle Type } & \text { Transit Bus } \\ \text { Vehicle ID Number (VIN) } & \text { 1N90401784A140216 } \\ \text { Vehicle Manufacturer } & \text { North American Bus Indust } \\ \text { Vehicle Model Year } & 2004 \\ \text { Gross Vehicle Weight (GVW) (Ib.) } & 42540 \\ \text { Vehicle Total Curb Weight (Ib.) } & 29840 \\ \text { Vehicle Tested Weight (Ib.) } & 35700 \\ \text { Odometer Reading (mile) } & 191800 \\ \text { Transmission Type } & \text { Auto } \\ \text { Transmission Configuration } & 5 \text { speed } \\ \text { Number of Axles } & 2 \\ \text { Engine Type } & \text { Detroit Diesel S-50 } \\ \text { Engine ID Number } & 6047 \text { MKLE } \\ \text { Engine Model Year } & 2004 \\ & \\ \text { Engine Displacement (Liter) } & 8.5 \\ \text { Number of Cylinders } & 6 \\ \text { Engine Rated Power (hp) } & 275 \\ \text { Primary Fuel } & \\ \text { Particulate Trap Manufacturer } & \text { Soybean oil Based Biodiesel } \\ \text { Catalytic Converter Manufacturer } & \text { none } \\ \text { Test Cycle } & \text { Miamidson } \\ \text { Test Date } & 4 / 16 / 08 \\ \text { Engineer } & \\ \text { Driver } & \text { Sindler, Petr } \\ & \text { England, Gary } \\ & \end{array}$

Emissions Results (g/mile)

\begin{tabular}{|c|c|c|c|c|c|c||c|c|c|}
\hline Run Seq. No. & $\mathrm{CO}$ & $\mathrm{NOx}^{1}$ & $\mathrm{NO}^{2}$ & $\mathrm{FIDHC}$ & $\mathrm{PM}$ & $\mathrm{CO}_{2}$ & $\mathrm{mile} / \mathrm{gal}$ & $\mathrm{BTU} / \mathrm{mile}$ & $\mathrm{Miles}$ \\
\hline $5307-1$ & 5.25 & 19.60 & 19.59 & 0.074 & $\mathrm{X}$ & 5024 & 2.02 & 63370 & 0.29 \\
\hline & & & & & & & & \\
\hline 5307 Average & 5.25 & 19.6 & 19.6 & 0.074 & $\mathrm{X}$ & 5024 & 2.02 & 63370 & 0.29 \\
\hline Std. Dev. & 0.00 & 0.0 & 0.0 & 0.000 & $\mathrm{X}$ & 0 & 0.00 & 0 & 0.00 \\
\hline CV\% & 0.0 & 0.0 & & 0.0 & $\mathrm{X}$ & 0.0 & 0.0 & 0.0 & 0.0 \\
\hline
\end{tabular}

x-Not Reportable, a-Outlier, b-HC Not Reportable(Residual HC), c-missing component, d-Coefficient of Variation Too Large, ebelow detectable limit

Test Purpose:

Acceleration ramps to $20 \mathrm{MPH}$ for power evaluation 
Test Sequence Number: 5314

WVU Test Reference Number: MDT-04208- Palm oil Based Biodiesel -MiamiD

$\begin{array}{ll}\text { Fleet Owner Full Name } & \text { Miami Dade Transit Agency } \\ \text { Fleet Address } & 3300 \text { Northwest 32 Ave. } \\ \text { Fleet Address (City, State, Zip) } & \text { Miami FL 33142 } \\ & \\ \text { Vehicle Type } & \text { Transit Bus } \\ \text { Vehicle ID Number (VIN) } & \text { N90401784A140216 } \\ \text { Vehicle Manufacturer } & \text { North American Bus Indust } \\ \text { Vehicle Model Year } & 2004 \\ \text { Gross Vehicle Weight (GVW) (Ib.) } & 42540 \\ \text { Vehicle Total Curb Weight (Ib.) } & 29840 \\ \text { Vehicle Tested Weight (Ib.) } & 35700 \\ \text { Odometer Reading (mile) } & 191800 \\ \text { Transmission Type } & \text { Auto } \\ \text { Transmission Configuration } & 5 \text { speed } \\ \text { Number of Axles } & 2 \\ \text { Engine Type } & \text { Detroit Diesel S-50 } \\ \text { Engine ID Number } & 6047 \mathrm{MKLE} \\ \text { Engine Model Year } & 2004 \\ \text { Engine Displacement (Liter) } & 8.5 \\ \text { Number of Cylinders } & 6 \\ \text { Engine Rated Power (hp) } & 275 \\ & \\ \text { Primary Fuel } & \text { Palm oil Based Biodiesel } \\ \text { Particulate Trap Manufacturer } & \text { none } \\ \text { Catalytic Converter Manufacturer } & \text { Nelson } \\ \text { Test Cycle } & \text { MiamiD } \\ \text { Test Date } & 4 / 18 / 08 \\ & \\ \text { Engineer } & \text { Sindler, Petr } \\ \text { Driver } & \text { England, Gary } \\ & \end{array}$

Emissions Results (g/mile)

\begin{tabular}{|c|c|c|c|c|c|c||c|c|c|}
\hline Run Seq. No. & $\mathrm{CO}$ & $\mathrm{NOx}^{1}$ & $\mathrm{NO}^{2}$ & $\mathrm{FIDHC}$ & $\mathrm{PM}$ & $\mathrm{CO}_{2}$ & $\mathrm{mile} / \mathrm{gal}$ & $\mathrm{BTU} / \mathrm{mile}$ & $\mathrm{Miles}$ \\
\hline $5314-1$ & 4.39 & 15.11 & 15.07 & 0.0085 & $\mathrm{X}$ & 4090 & 2.48 & 51590 & 0.73 \\
\hline & & & & & & & & \\
\hline 5314 Average & 4.39 & 15.1 & 15.1 & 0.0085 & $\mathrm{X}$ & 4090 & 2.48 & 51590 & 0.73 \\
\hline Std. Dev. & 0.00 & 0.0 & 0.0 & 0.000 & $\mathrm{X}$ & 0 & 0.00 & 0 & 0.00 \\
\hline CV\% & 0.0 & 0.0 & & 0.0 & $\mathrm{X}$ & 0.0 & 0.0 & 0.0 & 0.0 \\
\hline
\end{tabular}

x-Not Reportable, a-Outlier, b-HC Not Reportable(Residual HC), c-missing component, d-Coefficient of Variation Too Large, ebelow detectable limit 
Test Sequence Number: 5316

WVU Test Reference Number: MDT-04208- ULSD -MiamiD

$\begin{array}{ll}\text { Fleet Owner Full Name } & \text { Miami Dade Transit Agency } \\ \text { Fleet Address } & 3300 \text { Northwest 32 Ave. } \\ \text { Fleet Address (City, State, Zip) } & \text { Miami FL 33142 } \\ & \\ \text { Vehicle Type } & \text { Transit Bus } \\ \text { Vehicle ID Number (VIN) } & \text { N N90401784A140216 } \\ \text { Vehicle Manufacturer } & \text { North American Bus Indust } \\ \text { Vehicle Model Year } & 2004 \\ \text { Gross Vehicle Weight (GVW) (Ib.) } & 42540 \\ \text { Vehicle Total Curb Weight (Ib.) } & 29840 \\ \text { Vehicle Tested Weight (Ib.) } & 35700 \\ \text { Odometer Reading (mile) } & 191800 \\ \text { Transmission Type } & \text { Auto } \\ \text { Transmission Configuration } & 5 \text { speed } \\ \text { Number of Axles } & 2 \\ \text { Engine Type } & \text { Detroit Diesel S-50 } \\ \text { Engine ID Number } & 6047 \mathrm{MKLE} \\ \text { Engine Model Year } & 2004 \\ & \\ \text { Engine Displacement (Liter) } & 8.5 \\ \text { Number of Cylinders } & 6 \\ \text { Engine Rated Power (hp) } & 275 \\ \text { Primary Fuel } & \text { ULSD } \\ \text { Particulate Trap Manufacturer } & \text { none } \\ \text { Catalytic Converter Manufacturer } & \text { Nelson } \\ \text { Test Cycle } & \text { MiamiD } \\ \text { Test Date } & 4 / 18 / 08 \\ & \\ \text { Engineer } & \text { Sindler, Petr } \\ \text { Driver } & \text { England, Gary } \\ & \end{array}$

Emissions Results (g/mile)

\begin{tabular}{|c|c|c|c|c|c|c||c|c|c|}
\hline Run Seq. No. & $\mathrm{CO}$ & $\mathrm{NOx}^{1}$ & $\mathrm{NO}_{\mathrm{x}}{ }^{2}$ & $\mathrm{FIDHC}$ & $\mathrm{PM}$ & $\mathrm{CO}_{2}$ & $\mathrm{mile} / \mathrm{gal}$ & $\mathrm{BTU} / \mathrm{mile}$ & $\mathrm{Miles}$ \\
\hline $5316-1$ & 4.40 & 13.63 & 13.65 & 0.054 & $\mathrm{X}$ & 3748 & 2.57 & 49743 & 0.80 \\
\hline & & & & & & & & \\
\hline 5316 Average & 4.40 & 13.6 & 13.6 & 0.054 & $\mathrm{X}$ & 3748 & 2.57 & 49743 & 0.80 \\
\hline Std. Dev. & 0.00 & 0.0 & 0.0 & 0.000 & $\mathrm{X}$ & 0 & 0.00 & 0 & 0.00 \\
\hline CV\% & 0.0 & 0.0 & & 0.0 & $\mathrm{X}$ & 0.0 & 0.0 & 0.0 & 0.0 \\
\hline
\end{tabular}

x-Not Reportable, a-Outlier, b-HC Not Reportable(Residual HC), c-missing component, d-Coefficient of Variation Too Large, ebelow detectable limit 
Test Sequence Number: 5319

WVU Test Reference Number: MDT-05108- ULSD -MiamiD

$\begin{array}{ll}\text { Fleet Owner Full Name } & \text { Miami Dade Transit Agency } \\ \text { Fleet Address } & 3300 \text { Northwest } 32 \text { Ave. } \\ \text { Fleet Address (City, State, Zip) } & \text { Miami FL 33142 } \\ \text { Vehicle Type } & \text { Transit Bus } \\ \text { Vehicle ID Number (VIN) } & \text { N N90401765A140345 } \\ \text { Vehicle Manufacturer } & \text { North American Bus Indust } \\ \text { Vehicle Model Year } & 2005 \\ \text { Gross Vehicle Weight (GVW) (Ib.) } & 42550 \\ \text { Vehicle Total Curb Weight (Ib.) } & 29600 \\ \text { Vehicle Tested Weight (Ib.) } & 35700 \\ \text { Odometer Reading (mile) } & \\ \text { Transmission Type } & \text { Auto } \\ \text { Transmission Configuration } & 5 \text { speed } \\ \text { Number of Axles } & 2 \\ \text { Engine Type } & \text { Cummins ISM 280 } \\ \text { Engine ID Number } & 35130187 \\ \text { Engine Model Year } & 2005 \\ \text { Engine Displacement (Liter) } & 10.8 \\ \text { Number of Cylinders } & 6 \\ \text { Engine Rated Power (hp) } & 280 \\ \text { Primary Fuel } & \text { ULSD } \\ \text { Particulate Trap Manufacturer } & \text { none } \\ \text { Catalytic Converter Manufacturer } & \text { Nelson } \\ \text { Test Cycle } & \text { MiamiD } \\ \text { Test Date } & 4 / 19 / 08 \\ \text { Engineer } & \\ \text { Driver } & \text { Sindler, Petr } \\ & \text { England, Gary } \\ & \end{array}$

Emissions Results (g/mile) $\quad$ Fuel Economy

\begin{tabular}{|c|c|c|c|c|c|c|c|c|c|}
\hline Run Seq. No. & $\mathrm{CO}$ & $\mathrm{NOx}^{1}$ & $\mathrm{NO}^{2}$ & FIDHC & PM & $\mathrm{CO}_{2}$ & mile/gal & BTU/mile & Miles \\
\hline $5319-1$ & 2.36 & $\bar{X}$ & $\mathrm{X}$ & 0.24 & $X$ & 5128 & 1.88 & 67983 & 0.79 \\
\hline 5319 Average & 2.36 & $\mathrm{X}$ & $\mathrm{X}$ & 0.24 & $\mathrm{X}$ & 5128 & 1.88 & 67983 & 0.79 \\
\hline Std. Dev. & 0.00 & $\mathrm{X}$ & $\mathrm{X}$ & 0.00 & $\mathrm{X}$ & 0 & 0.00 & 0 & 0.00 \\
\hline CV\% & 0.0 & $X$ & & 0.0 & $\mathrm{X}$ & 0.0 & 0.0 & 0.0 & 0.0 \\
\hline
\end{tabular}

x-Not Reportable, a-Outlier, b-HC Not Reportable(Residual HC), c-missing component, d-Coefficient of Variation Too Large, ebelow detectable limit

Test Purpose:

Acceleration ramps from 0 to $20 \mathrm{mph}$ for power evaluation 
Test Sequence Number: 5322

WVU Test Reference Number: MDT-05108- Soybean oil Based Biodiesel -MiamiD

Fleet Owner Full Name

Fleet Address

Fleet Address (City, State, Zip)

Vehicle Type

Vehicle ID Number (VIN)

Vehicle Manufacturer

Vehicle Model Year

Gross Vehicle Weight (GVW) (Ib.)

Vehicle Total Curb Weight (Ib.)

Vehicle Tested Weight (Ib.)

Odometer Reading (mile)

Transmission Type

Transmission Configuration

Number of Axles

Engine Type

Engine ID Number

Engine Model Year

Engine Displacement (Liter)

Number of Cylinders

Engine Rated Power (hp)

Primary Fuel

Particulate Trap Manufacturer

Catalytic Converter Manufacturer

Test Cycle

Test Date

\section{Engineer}

Driver
Miami Dade Transit Agency

3300 Northwest 32 Ave.

Miami FL 33142

Transit Bus

1N90401765A140345

North American Bus Indust

2005

42550

29600

35700

Auto

5 speed

2

Cummins ISM 280

35130187

2005

10.8

6

280

Soybean oil Based Biodiesel

none

Nelson

MiamiD

4/19/08

Sindler, Petr

England, Gary

Emissions Results (g/mile)

Fuel Economy

\begin{tabular}{|c|c|c|c|c|c|c||c|c|c|}
\hline Run Seq. No. & $\mathrm{CO}$ & $\mathrm{NO}{ }^{1}$ & $\mathrm{NO}^{2}$ & $\mathrm{FIDHC}$ & $\mathrm{PM}$ & $\mathrm{CO}_{2}$ & $\mathrm{mile} / \mathrm{gal}$ & $\mathrm{BTU} / \mathrm{mile}$ & $\mathrm{Miles}$ \\
\hline $5322-1$ & 1.38 & 13.80 & 13.89 & 0.15 & $\mathrm{X}$ & 3911 & 2.60 & 49282 & 0.76 \\
\hline & & & & & & & & \\
\hline 5322 Average & 1.38 & 13.8 & 13.9 & 0.15 & $\mathrm{X}$ & 3911 & 2.60 & 49282 & 0.76 \\
\hline Std. Dev. & 0.00 & 0.0 & 0.0 & 0.00 & $\mathrm{X}$ & 0 & 0.00 & 0 & 0.00 \\
\hline CV\% & 0.0 & 0.0 & & 0.0 & $\mathrm{X}$ & 0.0 & 0.0 & 0.0 & 0.0 \\
\hline
\end{tabular}

x-Not Reportable, a-Outlier, b-HC Not Reportable(Residual HC), c-missing component, d-Coefficient of Variation Too Large, ebelow detectable limit 
Test Sequence Number: 5323

WVU Test Reference Number: MDT-05108- Palm oil Based Biodiesel -MiamiD

Fleet Owner Full Name

Fleet Address

Fleet Address (City, State, Zip)

Vehicle Type

Vehicle ID Number (VIN)

Vehicle Manufacturer

Vehicle Model Year

Gross Vehicle Weight (GVW) (Ib.)

Vehicle Total Curb Weight (Ib.)

Vehicle Tested Weight (Ib.)

Odometer Reading (mile)

Transmission Type

Transmission Configuration

Number of Axles

Engine Type

Engine ID Number

Engine Model Year

Engine Displacement (Liter)

Number of Cylinders

Engine Rated Power (hp)

Primary Fuel

Particulate Trap Manufacturer

Catalytic Converter Manufacturer

Test Cycle

Test Date

\section{Engineer}

Driver
Miami Dade Transit Agency

3300 Northwest 32 Ave.

Miami FL 33142

Transit Bus

1N90401765A140345

North American Bus Indust

2005

42550

29600

35700

Auto

5 speed

2

Cummins ISM 280

35130187

2005

10.8

6

280

Palm oil Based Biodiesel

none

Nelson

MiamiD

4/19/08

Sindler, Petr

England, Gary

Emissions Results (g/mile)

Fuel Economy

\begin{tabular}{|c|c|c|c|c|c|c||c|c|c|}
\hline Run Seq. No. & $\mathrm{CO}$ & $\mathrm{NO}{ }^{1}$ & $\mathrm{NOx}^{2}$ & $\mathrm{FIDHC}$ & $\mathrm{PM}$ & $\mathrm{CO}_{2}$ & $\mathrm{mile} / \mathrm{gal}$ & $\mathrm{BTU} / \mathrm{mile}$ & $\mathrm{Miles}$ \\
\hline $5323-1$ & 1.81 & 14.46 & 14.51 & 0.38 & $\mathrm{X}$ & 4045 & 2.51 & 50985 & 0.72 \\
\hline & & & & & & & & \\
\hline 5323 Average & 1.81 & 14.5 & 14.5 & 0.38 & $\mathrm{X}$ & 4045 & 2.51 & 50985 & 0.72 \\
\hline Std. Dev. & 0.00 & 0.0 & 0.0 & 0.00 & $\mathrm{X}$ & 0 & 0.00 & 0 & 0.00 \\
\hline CV\% & 0.0 & 0.0 & & 0.0 & $\mathrm{X}$ & 0.0 & 0.0 & 0.0 & 0.0 \\
\hline
\end{tabular}

x-Not Reportable, a-Outlier, b-HC Not Reportable(Residual HC), c-missing component, d-Coefficient of Variation Too Large, ebelow detectable limit 


\section{Appendix C. Summary Short Reports of In-Use Tests}




\section{Appendix Figure C-1 In-use Test Summary for DDC (Bus 04208) with ULSD - Leg 1}

\begin{tabular}{|c|c|c|c|c|c|c|}
\hline Seq. \& Run No. & \multicolumn{2}{|c|}{ M190045- 4} & Test Date & \multicolumn{3}{|c|}{$4-10-2008$} \\
\hline Leg & \multicolumn{6}{|c|}{ Miami-Dade Rt 7} \\
\hline Test Location & \multicolumn{6}{|l|}{ Miami } \\
\hline Engine Manuf. & \multicolumn{2}{|l|}{ DDC } & Engine $\mathrm{S} / \mathrm{N}$ & \multicolumn{3}{|c|}{ 04R0046535 } \\
\hline Engine Model Year & \multicolumn{2}{|l|}{2004} & VIN \# & \multicolumn{3}{|c|}{ 1N90401784A140216 } \\
\hline Engine Model & \multicolumn{6}{|l|}{ Series 50} \\
\hline Engine Configuration & \multicolumn{6}{|l|}{ Inline - 4} \\
\hline Engine Displacement & \multicolumn{6}{|l|}{8.5} \\
\hline Aftertreatment & \multicolumn{6}{|c|}{ Donaldson - Oxidation Catalyst } \\
\hline Engineer & \multicolumn{6}{|l|}{ Ron Jarrett } \\
\hline Ambient & \multicolumn{2}{|l|}{ Temp. } & \multicolumn{2}{|l|}{ Press } & \multicolumn{2}{|l|}{$\mathrm{RH}$} \\
\hline & \multicolumn{2}{|l|}{ deg. F } & \multicolumn{2}{|l|}{ in $\mathrm{Hg}$} & \multicolumn{2}{|l|}{$\%$} \\
\hline Pre & \multicolumn{2}{|l|}{83} & \multicolumn{2}{|l|}{30} & \multicolumn{2}{|l|}{69} \\
\hline Post & \multicolumn{2}{|l|}{82} & \multicolumn{2}{|l|}{29.99} & \multicolumn{2}{|l|}{65} \\
\hline ECU Distance & Miles & 4.86 & GPS Distance & & Miles & 4.67 \\
\hline ECU Inferred Work & bhp-hr & 37.36 & Data Duration & & $\mathrm{s}$ & 2032.6 \\
\hline $\mathrm{bsCO} 2$ & g/bhp-hr & 482.6 & Distance Specific CO2 & & $\mathrm{g} / \mathrm{mile}$ & 3705 \\
\hline bsNOx (Mexa) & g/bhp-hr & 2.09 & Distance Specific NOx (Mexa) & & $\mathrm{g} / \mathrm{mile}$ & 16.08 \\
\hline bsNOx Corr (Mexa) & $\mathrm{g} / \mathrm{bhp}-\mathrm{hr}$ & 2.30 & Distance Specific NOx Corr (Me) & & $\mathrm{g} / \mathrm{mile}$ & 17.71 \\
\hline bsNOx (EC) & g/bhp-hr & 1.71 & Distance Specific NOx (EC) & & $\mathrm{g} / \mathrm{mile}$ & 13.19 \\
\hline bsNOx Corr (EC) & g/bhp-hr & 1.89 & Distance Specific NOx Corr (EC) & & $\mathrm{g} / \mathrm{mile}$ & 14.52 \\
\hline Bsfc & lb/bhp-hr & 0.334 & Fuel Economy & & miles/gal & 2.59 \\
\hline \multicolumn{7}{|l|}{ Cycle Fuel Consumption } \\
\hline Emissions (gal) & ECU (gal) & Per Diff (\%) & & & & \\
\hline 1.87 & 1.98 & -5.94 & & & & \\
\hline
\end{tabular}




\section{Appendix Figure C-2 In-use Test Summary for DDC (Bus 04208) with ULSD - Leg 2}

\begin{tabular}{|c|c|c|c|c|c|c|}
\hline Seq. \& Run No. & \multicolumn{2}{|c|}{ M190045-5 } & Test Date & \multicolumn{3}{|c|}{ 4-10-2008 } \\
\hline Leg & \multicolumn{6}{|c|}{ Miami-Dade Rt 7} \\
\hline Test Location & \multicolumn{6}{|l|}{ Miami } \\
\hline Engine Manuf. & \multicolumn{2}{|l|}{ DDC } & Engine $\mathrm{S} / \mathrm{N}$ & \multicolumn{3}{|c|}{ 04R0046535 } \\
\hline Engine Model Year & \multicolumn{2}{|l|}{2004} & VIN \# & \multicolumn{3}{|c|}{ 1N90401784A140216 } \\
\hline Engine Model & \multicolumn{6}{|l|}{ Series 50} \\
\hline Engine Configuration & \multicolumn{6}{|l|}{ Inline - 4} \\
\hline Engine Displacement & \multicolumn{6}{|l|}{8.5} \\
\hline Aftertreatment & \multicolumn{6}{|c|}{ Donaldson - Oxidation Catalyst } \\
\hline Engineer & \multicolumn{6}{|l|}{ Ron Jarrett } \\
\hline \multirow[t]{2}{*}{ Ambient } & \multicolumn{2}{|l|}{ Temp. } & \multicolumn{2}{|l|}{ Press } & \multicolumn{2}{|l|}{$\mathrm{RH}$} \\
\hline & \multicolumn{2}{|l|}{ deg. $\mathrm{F}$} & \multicolumn{2}{|l|}{ in $\mathrm{Hg}$} & \multicolumn{2}{|l|}{$\%$} \\
\hline Pre & \multicolumn{2}{|l|}{82} & \multicolumn{2}{|l|}{29.99} & \multicolumn{2}{|l|}{72} \\
\hline Post & \multicolumn{2}{|l|}{86} & \multicolumn{2}{|l|}{29.99} & \multicolumn{2}{|l|}{60} \\
\hline ECU Distance & Miles & 4.87 & GPS Distance & & Miles & 4.63 \\
\hline ECU Inferred Work & bhp-hr & 43.68 & Data Duration & & $\mathrm{s}$ & 2266.8 \\
\hline $\mathrm{bsCO} 2$ & g/bhp-hr & 513.5 & Distance Specific CO2 & & $\mathrm{g} / \mathrm{mile}$ & 4604 \\
\hline bsNOx (Mexa) & g/bhp-hr & 1.91 & Distance Specific NOx (Mexa) & & $\mathrm{g} / \mathrm{mile}$ & 17.13 \\
\hline bsNOx Corr (Mexa) & g/bhp-hr & 2.12 & Distance Specific NOx Corr (Me) & & $\mathrm{g} / \mathrm{mile}$ & 19.04 \\
\hline bsNOx (EC) & g/bhp-hr & 1.58 & Distance Specific NOx (EC) & & $\mathrm{g} / \mathrm{mile}$ & 14.19 \\
\hline bsNOx Corr (EC) & g/bhp-hr & 1.76 & Distance Specific NOx Corr (EC) & & $\mathrm{g} / \mathrm{mile}$ & 15.78 \\
\hline Bsfc & $\mathrm{lb} / \mathrm{bhp}-\mathrm{hr}$ & 0.355 & Fuel Economy & & miles/gal & 2.09 \\
\hline \multicolumn{7}{|l|}{ Cycle Fuel Consumption } \\
\hline Emissions (gal) & ECU (gal) & Per Diff (\%) & & & & \\
\hline 2.32 & 2.19 & 5.61 & & & & \\
\hline
\end{tabular}


Appendix Figure C-3 In-use Test Summary for DDC (Bus 04208) with B20 (Soybean Oil) Leg 1

\begin{tabular}{|c|c|c|c|c|c|c|}
\hline Seq. \& Run No. & \multicolumn{2}{|l|}{ M190058-2 } & Test Date & \multicolumn{3}{|c|}{ 4-15-2008 } \\
\hline Leg & \multicolumn{6}{|c|}{ Miami-Dade Rt 7} \\
\hline Test Location & \multicolumn{6}{|l|}{ Miami } \\
\hline Engine Manuf. & \multicolumn{2}{|l|}{ DDC } & Engine $\mathrm{S} / \mathrm{N}$ & \multicolumn{3}{|c|}{ 04R0046535 } \\
\hline Engine Model Year & \multicolumn{2}{|l|}{2004} & VIN \# & \multicolumn{3}{|c|}{ 1N90401784A140216 } \\
\hline Engine Model & \multicolumn{6}{|l|}{ Series 50} \\
\hline Engine Configuration & \multicolumn{6}{|l|}{ Inline - 4} \\
\hline Engine Displacement & \multicolumn{6}{|l|}{8.5} \\
\hline Aftertreatment & \multicolumn{6}{|c|}{ Donaldson - Oxidation Catalyst } \\
\hline Engineer & \multicolumn{6}{|l|}{ Ron Jarrett } \\
\hline Ambient & \multicolumn{2}{|l|}{ Temp. } & \multicolumn{2}{|l|}{ Press } & \multicolumn{2}{|l|}{$\mathrm{RH}$} \\
\hline & \multicolumn{2}{|l|}{ deg. $F$} & \multicolumn{2}{|l|}{ in $\mathrm{Hg}$} & \multicolumn{2}{|l|}{$\%$} \\
\hline Pre & \multicolumn{2}{|l|}{70} & \multicolumn{2}{|l|}{30.03} & \multicolumn{2}{|l|}{67} \\
\hline Post & \multicolumn{2}{|l|}{70} & \multicolumn{2}{|l|}{30.02} & \multicolumn{2}{|l|}{74} \\
\hline ECU Distance & Miles & 4.87 & \multicolumn{2}{|l|}{ GPS Distance } & Miles & $\mathrm{N} / \mathrm{A}$ \\
\hline ECU Inferred Work & bhp-hr & 40.42 & \multicolumn{2}{|l|}{ Data Duration } & $\mathrm{s}$ & 2472 \\
\hline $\mathrm{bsCO} 2$ & g/bhp-hr & 360.86 & \multicolumn{2}{|l|}{ Distance Specific CO2 } & $\mathrm{g} / \mathrm{mile}$ & 2989 \\
\hline bsNOx (Mexa) & g/bhp-hr & 2.14 & \multicolumn{2}{|l|}{ Distance Specific NOx (Mexa) } & $\mathrm{g} / \mathrm{mile}$ & 17.80 \\
\hline bsNOx Corr (Mexa) & g/bhp-hr & 2.16 & \multicolumn{2}{|c|}{ Distance Specific NOx Corr (Mexa) } & $\mathrm{g} / \mathrm{mile}$ & 17.91 \\
\hline bsNOx (EC) & g/bhp-hr & 1.57 & \multicolumn{2}{|l|}{ Distance Specific NOx (EC) } & $\mathrm{g} / \mathrm{mile}$ & 13.04 \\
\hline bsNOx Corr (EC) & g/bhp-hr & 1.58 & \multicolumn{2}{|l|}{ Distance Specific NOx Corr (EC) } & $\mathrm{g} / \mathrm{mile}$ & 13.13 \\
\hline Bsfc & $\mathrm{lb} / \mathrm{bhp}-\mathrm{hr}$ & 0.249 & \multicolumn{2}{|l|}{ Fuel Economy } & miles/gal & 3.22 \\
\hline Cycle Fuel Consumptio & & & & & & \\
\hline Emissions (gal) & ECU (gal) & Per Diff (\%) & & & & \\
\hline 1.51 & 2.14 & -41.7 & & & & \\
\hline
\end{tabular}




\section{Appendix Figure C-4 In-use Test Summary for DDC (Bus 04208) with B20 (Soybean Oil) -}

Leg 2

\begin{tabular}{|c|c|c|c|c|c|c|}
\hline Seq. \& Run No. & \multicolumn{2}{|c|}{ M190058-3 } & Test Date & \multicolumn{3}{|c|}{ 4-15-2008 } \\
\hline Leg & \multicolumn{6}{|c|}{ Miami-Dade Rt 7} \\
\hline Test Location & \multicolumn{6}{|l|}{ Miami } \\
\hline Engine Manuf. & \multicolumn{2}{|l|}{ DDC } & Engine $\mathrm{S} / \mathrm{N}$ & \multicolumn{3}{|c|}{ 04R0046535 } \\
\hline Engine Model Year & \multicolumn{2}{|l|}{2004} & VIN \# & \multicolumn{3}{|c|}{ 1N90401784A140216 } \\
\hline Engine Model & \multicolumn{6}{|l|}{ Series 50} \\
\hline Engine Configuration & \multicolumn{6}{|l|}{ Inline - 4} \\
\hline Engine Displacement & \multicolumn{6}{|l|}{8.5} \\
\hline Aftertreatment & \multicolumn{6}{|c|}{ Donaldson - Oxidation Catalyst } \\
\hline Engineer & \multicolumn{6}{|l|}{ Ron Jarrett } \\
\hline Ambient & \multicolumn{2}{|l|}{\begin{tabular}{|l} 
Temp. \\
\end{tabular}} & \multicolumn{2}{|l|}{ Press } & \multicolumn{2}{|l|}{$\mathrm{RH}$} \\
\hline & \multicolumn{2}{|l|}{ deg. $F$} & \multicolumn{2}{|l|}{ in $\mathrm{Hg}$} & \multicolumn{2}{|l|}{$\%$} \\
\hline Pre & \multicolumn{2}{|l|}{70} & \multicolumn{2}{|l|}{30.02} & \multicolumn{2}{|l|}{74} \\
\hline Post & \multicolumn{2}{|l|}{67} & \multicolumn{2}{|l|}{30.02} & \multicolumn{2}{|l|}{70} \\
\hline ECU Distance & Miles & 4.80 & GPS Distance & & Miles & $\mathrm{N} / \mathrm{A}$ \\
\hline ECU Inferred Work & bhp-hr & 38.92 & Data Duration & & $\mathrm{s}$ & 2249.4 \\
\hline $\mathrm{bsCO} 2$ & $\mathrm{~g} / \mathrm{bhp}-\mathrm{hr}$ & 486.38 & Distance Specific $\mathrm{CO} 2$ & & $\mathrm{~g} / \mathrm{mile}$ & 3938 \\
\hline bsNOx (Mexa) & $\mathrm{g} / \mathrm{bhp}-\mathrm{hr}$ & 2.27 & Distance Specific NOx (Mexa) & & $\mathrm{g} / \mathrm{mile}$ & 18.40 \\
\hline bsNOx Corr (Mexa) & g/bhp-hr & 2.28 & Distance Specific NOx Corr (Me) & & $\mathrm{g} / \mathrm{mile}$ & 18.51 \\
\hline bsNOx (EC) & g/bhp-hr & 1.73 & Distance Specific NOx (EC) & & $\mathrm{g} / \mathrm{mile}$ & 14.05 \\
\hline bsNOx Corr (EC) & g/bhp-hr & 1.74 & Distance Specific NOx Corr (EC) & & $\mathrm{g} / \mathrm{mile}$ & 14.14 \\
\hline Bsfc & $\mathrm{lb} / \mathrm{bhp}-\mathrm{hr}$ & 0.336 & Fuel Economy & & miles/gal & 2.44 \\
\hline \multicolumn{7}{|l|}{ Cycle Fuel Consumption } \\
\hline Emissions (gal) & ECU (gal) & Per Diff (\%) & & & & \\
\hline 1.96 & 2.04 & -4.28 & & & & \\
\hline
\end{tabular}




\section{Appendix Figure C-5 In-use Test Summary for DDC (Bus 04208) with B20 (Palm Oil) - Leg 1}

\begin{tabular}{|c|c|c|c|c|c|c|}
\hline Seq. \& Run No. & \multicolumn{2}{|c|}{ M190057-2 } & Test Date & \multicolumn{3}{|c|}{$4-15-2008$} \\
\hline Leg & \multicolumn{6}{|c|}{ Miami-Dade Rt 7} \\
\hline Test Location & \multicolumn{6}{|l|}{ Miami } \\
\hline Engine Manuf. & \multicolumn{2}{|l|}{ DDC } & Engine $\mathrm{S} / \mathrm{N}$ & \multicolumn{3}{|c|}{ 04R0046535 } \\
\hline Engine Model Year & \multicolumn{2}{|l|}{2004} & VIN \# & \multicolumn{3}{|c|}{ 1N90401784A140216 } \\
\hline Engine Model & \multicolumn{6}{|l|}{ Series 50} \\
\hline Engine Configuration & \multicolumn{6}{|l|}{ Inline - 4} \\
\hline Engine Displacement & \multicolumn{6}{|l|}{8.5} \\
\hline Aftertreatment & \multicolumn{6}{|c|}{ Donaldson - Oxidation Catalyst } \\
\hline Engineer & \multicolumn{6}{|l|}{ Ron Jarrett } \\
\hline Ambient & \multicolumn{2}{|l|}{ Temp. } & \multicolumn{2}{|l|}{ Press } & \multicolumn{2}{|l|}{$\mathrm{RH}$} \\
\hline & \multicolumn{2}{|l|}{ deg. $F$} & \multicolumn{2}{|l|}{ in $\mathrm{Hg}$} & \multicolumn{2}{|l|}{$\%$} \\
\hline Pre & \multicolumn{2}{|l|}{64} & \multicolumn{2}{|l|}{31.11} & \multicolumn{2}{|l|}{52} \\
\hline Post & \multicolumn{2}{|l|}{69} & \multicolumn{2}{|l|}{30.1} & \multicolumn{2}{|l|}{59} \\
\hline ECU Distance & Miles & 4.92 & GPS Distance & & Miles & $\mathrm{N} / \mathrm{A}$ \\
\hline ECU Inferred Work & bhp-hr & 42.16 & Data Duration & & $\mathrm{s}$ & 2373.6 \\
\hline $\mathrm{bsCO} 2$ & g/bhp-hr & -89.09 & Distance Specific CO2 & & $\mathrm{g} / \mathrm{mile}$ & -763 \\
\hline bsNOx (Mexa) & $\mathrm{g} / \mathrm{bhp}-\mathrm{hr}$ & 2.07 & Distance Specific NOx (Mexa) & & $\mathrm{g} / \mathrm{mile}$ & 17.81 \\
\hline bsNOx Corr (Mexa) & g/bhp-hr & 2.06 & Distance Specific NOx Corr (Me) & & $\mathrm{g} / \mathrm{mile}$ & 17.67 \\
\hline bsNOx (EC) & g/bhp-hr & 1.97 & Distance Specific NOx (EC) & & $\mathrm{g} / \mathrm{mile}$ & 16.95 \\
\hline bsNOx Corr (EC) & g/bhp-hr & 1.96 & Distance Specific NOx Corr (EC) & & $\mathrm{g} / \mathrm{mile}$ & 16.82 \\
\hline Bsfc & $\mathrm{lb} / \mathrm{bhp}-\mathrm{hr}$ & -0.061 & Fuel Economy & & miles/gal & -12.62 \\
\hline \multicolumn{7}{|l|}{ Cycle Fuel Consumption } \\
\hline Emissions (gal) & ECU (gal) & Per Diff (\%) & & & & \\
\hline-0.38 & 2.21 & -666.88 & & & & \\
\hline
\end{tabular}




\section{Appendix Figure C-6 In-use Test Summary for DDC (Bus 04208) with B20 (Palm Oil) -}

Leg 2

\begin{tabular}{|c|c|c|c|c|c|c|}
\hline Seq. \& Run No. & \multicolumn{2}{|c|}{ M190057-3 } & Test Date & \multicolumn{3}{|c|}{ 4-15-2008 } \\
\hline Leg & \multicolumn{6}{|c|}{ Miami-Dade Rt 7} \\
\hline Test Location & \multicolumn{6}{|l|}{ Miami } \\
\hline Engine Manuf. & \multicolumn{2}{|l|}{$\mathrm{DDC}$} & Engine $\mathrm{S} / \mathrm{N}$ & \multicolumn{3}{|c|}{ 04R0046535 } \\
\hline Engine Model Year & \multicolumn{2}{|l|}{2004} & VIN \# & \multicolumn{3}{|c|}{ 1N90401784A140216 } \\
\hline Engine Model & \multicolumn{6}{|l|}{ Series 50} \\
\hline Engine Configuration & \multicolumn{6}{|l|}{ Inline - 4} \\
\hline Engine Displacement & \multicolumn{6}{|l|}{8.5} \\
\hline Aftertreatment & \multicolumn{6}{|c|}{ Donaldson - Oxidation Catalyst } \\
\hline Engineer & \multicolumn{6}{|l|}{ Ron Jarrett } \\
\hline Ambient & \multicolumn{2}{|l|}{ Temp. } & \multicolumn{2}{|l|}{ Press } & \multicolumn{2}{|l|}{$\mathrm{RH}$} \\
\hline & \multicolumn{2}{|l|}{ deg. $F$} & \multicolumn{2}{|l|}{ in $\mathrm{Hg}$} & \multicolumn{2}{|l|}{$\%$} \\
\hline Pre & \multicolumn{2}{|l|}{69} & \multicolumn{2}{|l|}{30.1} & \multicolumn{2}{|l|}{59} \\
\hline Post & \multicolumn{2}{|l|}{67} & \multicolumn{2}{|l|}{30.08} & \multicolumn{2}{|l|}{66} \\
\hline ECU Distance & Miles & 4.81 & \multicolumn{2}{|l|}{ GPS Distance } & Miles & $\mathrm{N} / \mathrm{A}$ \\
\hline ECU Inferred Work & bhp-hr & 33.45 & \multicolumn{2}{|l|}{ Data Duration } & $\mathrm{s}$ & 2130.8 \\
\hline $\mathrm{bsCO} 2$ & $\mathrm{~g} / \mathrm{bhp}-\mathrm{hr}$ & 489.78 & \multicolumn{2}{|l|}{ Distance Specific CO2 } & $\mathrm{g} / \mathrm{mile}$ & 3401 \\
\hline bsNOx (Mexa) & g/bhp-hr & 2.20 & \multicolumn{2}{|l|}{ Distance Specific NOx (Mexa) } & $\mathrm{g} / \mathrm{mile}$ & 15.28 \\
\hline bsNOx Corr (Mexa) & $\mathrm{g} / \mathrm{bhp}-\mathrm{hr}$ & 2.20 & \multicolumn{2}{|l|}{ Distance Specific NOx Corr (Mexa) } & $\mathrm{g} / \mathrm{mile}$ & 15.28 \\
\hline bsNOx (EC) & $\mathrm{g} / \mathrm{bhp}-\mathrm{hr}$ & 1.87 & \multicolumn{2}{|l|}{ Distance Specific NOx (EC) } & $\mathrm{g} / \mathrm{mile}$ & 12.99 \\
\hline bsNOx Corr (EC) & g/bhp-hr & 1.87 & \multicolumn{2}{|l|}{ Distance Specific NOx Corr (EC) } & $\mathrm{g} / \mathrm{mile}$ & 12.99 \\
\hline Bsfc & lb/bhp-hr & 0.339 & \multicolumn{2}{|l|}{ Fuel Economy } & miles/gal & 2.83 \\
\hline Cycle Fuel Consumptiol & & & & & & \\
\hline Emissions (gal) & ECU (gal) & Per Diff (\%) & & & & \\
\hline 1.70 & 1.73 & -1.74 & & & & \\
\hline
\end{tabular}


Appendix Figure C-7 In-use Test Summary for Cummins (Bus 05108) with ULSD - Leg 1

\begin{tabular}{|c|c|c|c|c|c|}
\hline Seq. \& Run No. & \multicolumn{2}{|c|}{ M190082 - 2} & Test Date & \multicolumn{2}{|l|}{$5-1-2008$} \\
\hline Leg & \multicolumn{5}{|c|}{ Miami 1 ULSD } \\
\hline Test Location & \multicolumn{5}{|l|}{ Miami } \\
\hline Engine Manuf. & \multicolumn{2}{|l|}{ Cummins } & Engine $\mathrm{S} / \mathrm{N}$ & \multicolumn{2}{|l|}{35130187} \\
\hline Engine Model Year & \multicolumn{2}{|l|}{2005} & VIN \# & \multicolumn{2}{|c|}{ 1N90401765A140345 } \\
\hline Engine Model & \multicolumn{5}{|l|}{ ISM } \\
\hline Engine Configuration & \multicolumn{5}{|l|}{ Inline - 6} \\
\hline Engine Displacement & \multicolumn{5}{|l|}{10.8} \\
\hline Aftertreatment & \multicolumn{5}{|c|}{ Donaldson - Catalyst } \\
\hline Engineer & \multicolumn{5}{|l|}{ Dan Carder } \\
\hline Ambient & \multicolumn{2}{|l|}{ Temp. } & Press & \multicolumn{2}{|l|}{$\mathrm{RH}$} \\
\hline & \multicolumn{2}{|l|}{ deg. F } & in $\mathrm{Hg}$ & \multicolumn{2}{|l|}{$\%$} \\
\hline Pre & \multicolumn{2}{|l|}{82} & 30.05 & \multicolumn{2}{|l|}{54} \\
\hline Post & \multicolumn{2}{|l|}{78} & 30.04 & \multicolumn{2}{|l|}{60} \\
\hline ECU Distance & Miles & 5.13 & GPS Distance & Miles & 4.88 \\
\hline ECU Inferred Work & bhp-hr & 38.59 & Data Duration & $\mathrm{s}$ & 2298.6 \\
\hline $\mathrm{bsCO} 2$ & g/bhp-hr & 503.6 & Distance Specific CO2 & $\mathrm{g} / \mathrm{mile}$ & 3786 \\
\hline bsNOx (Mexa) & g/bhp-hr & 2.28 & Distance Specific NOx (Mexa) & $\mathrm{g} / \mathrm{mile}$ & 17.17 \\
\hline bsNOx Corr (Mexa) & g/bhp-hr & 2.35 & Distance Specific NOx Corr (Mex & $\mathrm{g} / \mathrm{mile}$ & 17.71 \\
\hline bsNOx (EC) & g/bhp-hr & 2.02 & Distance Specific NOx (EC) & $\mathrm{g} / \mathrm{mile}$ & 15.22 \\
\hline bsNOx Corr (EC) & g/bhp-hr & 2.08 & Distance Specific NOx Corr (EC) & $\mathrm{g} / \mathrm{mile}$ & 15.69 \\
\hline Bsfc & $\mathrm{lb} / \mathrm{bhp}-\mathrm{hr}$ & 0.348 & Fuel Economy & miles/gal & 2.54 \\
\hline \multicolumn{6}{|l|}{ Cycle Fuel Consumption } \\
\hline Emissions (gal) & ECU (gal) & Per Diff (\%) & & & \\
\hline 2.01 & 2.08 & -3.18 & & & \\
\hline
\end{tabular}




\section{Appendix Figure C-8 In-use Test Summary for Cummins (Bus 05108) with ULSD - Leg 2}

\begin{tabular}{|c|c|c|c|c|c|c|}
\hline Seq. \& Run No. & \multicolumn{2}{|c|}{ M190082- 3} & Test Date & \multicolumn{3}{|c|}{$5-1-2008$} \\
\hline Leg & \multicolumn{6}{|c|}{ Miami 2 ULSD } \\
\hline Test Location & \multicolumn{6}{|l|}{ Miami } \\
\hline Engine Manuf. & \multicolumn{2}{|l|}{ Cummins } & Engine $\mathrm{S} / \mathrm{N}$ & \multicolumn{3}{|c|}{35130187} \\
\hline Engine Model Year & \multicolumn{2}{|l|}{2005} & VIN \# & \multicolumn{3}{|c|}{ 1N90401765A140345 } \\
\hline Engine Model & \multicolumn{6}{|l|}{ ISM } \\
\hline Engine Configuration & \multicolumn{6}{|l|}{ Inline - 6} \\
\hline Engine Displacement & \multicolumn{6}{|l|}{10.8} \\
\hline Aftertreatment & \multicolumn{6}{|c|}{ Donaldson - Catalyst } \\
\hline Engineer & \multicolumn{6}{|l|}{ Dan Carder } \\
\hline Ambient & \multicolumn{2}{|l|}{ Temp. } & \multicolumn{2}{|l|}{ Press } & \multicolumn{2}{|l|}{$\mathrm{RH}$} \\
\hline & \multicolumn{2}{|l|}{ deg. $F$} & \multicolumn{2}{|l|}{ in $\mathrm{Hg}$} & \multicolumn{2}{|l|}{$\%$} \\
\hline Pre & \multicolumn{2}{|l|}{78} & \multicolumn{2}{|l|}{30.04} & \multicolumn{2}{|l|}{60} \\
\hline Post & \multicolumn{2}{|l|}{77} & \multicolumn{2}{|l|}{30.04} & \multicolumn{2}{|l|}{55} \\
\hline ECU Distance & Miles & 5.00 & GPS Distance & & Miles & 4.78 \\
\hline ECU Inferred Work & bhp-hr & 41.3 & Data Duration & & $\mathrm{s}$ & 2814.6 \\
\hline $\mathrm{bsCO} 2$ & g/bhp-hr & 492.01 & Distance Specific CO2 & & $\mathrm{g} / \mathrm{mile}$ & 4065 \\
\hline bsNOx (Mexa) & g/bhp-hr & 2.21 & Distance Specific NOx (Mexa) & & $\mathrm{g} / \mathrm{mile}$ & 18.27 \\
\hline bsNOx Corr (Mexa) & g/bhp-hr & 2.26 & Distance Specific NOx Corr (Me) & & $\mathrm{g} / \mathrm{mile}$ & 18.73 \\
\hline bsNOx (EC) & g/bhp-hr & 1.96 & Distance Specific NOx (EC) & & $\mathrm{g} / \mathrm{mile}$ & 16.22 \\
\hline bsNOx Corr (EC) & g/bhp-hr & 2.01 & Distance Specific NOx Corr (EC) & & $\mathrm{g} / \mathrm{mile}$ & 16.63 \\
\hline Bsfc & $\mathrm{lb} / \mathrm{bhp}-\mathrm{hr}$ & 0.340 & Fuel Economy & & miles/gal & 2.36 \\
\hline \multicolumn{7}{|l|}{ Cycle Fuel Consumption } \\
\hline Emissions (gal) & ECU (gal) & Per Diff (\%) & & & & \\
\hline 2.111914478 & 2.15855 & -2.2082 & & & & \\
\hline
\end{tabular}




\section{Appendix Figure C-9 In-use Test Summary for Cummins (Bus 05108) with B20 (Soybean Oil) - Leg 1}

\begin{tabular}{|c|c|c|c|c|c|}
\hline Seq. \& Run No. & \multicolumn{2}{|c|}{ M190083-2 } & Test Date & \multicolumn{2}{|l|}{$5-2-2008$} \\
\hline Leg & \multicolumn{5}{|c|}{ Miami 1 B20 Soybean oil Based Diesel } \\
\hline Test Location & \multicolumn{5}{|l|}{ Miami } \\
\hline Engine Manuf. & \multicolumn{2}{|l|}{ Cummins } & Engine $\mathrm{S} / \mathrm{N}$ & \multicolumn{2}{|l|}{35130187} \\
\hline Engine Model Year & \multicolumn{2}{|l|}{2005} & VIN \# & \multicolumn{2}{|c|}{ 1N90401765A140345 } \\
\hline Engine Model & \multicolumn{5}{|l|}{ ISM } \\
\hline Engine Configuration & \multicolumn{5}{|l|}{ Inline -6} \\
\hline Engine Displacement & \multicolumn{5}{|l|}{10.8} \\
\hline Aftertreatment & \multicolumn{5}{|c|}{ Donaldson - Catalyst } \\
\hline Engineer & \multicolumn{5}{|l|}{ Dan Carder } \\
\hline Ambient & \multicolumn{2}{|l|}{ Temp. } & Press & \multicolumn{2}{|l|}{$\mathrm{RH}$} \\
\hline & \multicolumn{2}{|l|}{ deg. $F$} & in $\mathrm{Hg}$ & \multicolumn{2}{|l|}{$\%$} \\
\hline Pre & \multicolumn{2}{|l|}{76} & 30.05 & \multicolumn{2}{|l|}{59} \\
\hline Post & \multicolumn{2}{|l|}{78} & 30.06 & \multicolumn{2}{|l|}{64} \\
\hline ECU Distance & Miles & 4.91 & GPS Distance & Miles & 4.64 \\
\hline ECU Inferred Work & bhp-hr & 43.18 & Data Duration & $\mathrm{s}$ & 2757 \\
\hline $\mathrm{bsCO} 2$ & g/bhp-hr & 483.3 & Distance Specific CO2 & $\mathrm{g} / \mathrm{mile}$ & 4248 \\
\hline bsNOx (Mexa) & g/bhp-hr & 2.01 & Distance Specific NOx (Mexa) & $\mathrm{g} / \mathrm{mile}$ & 17.72 \\
\hline bsNOx Corr (Mexa) & g/bhp-hr & 2.03 & Distance Specific NOx Corr (Me) & $\mathrm{g} / \mathrm{mile}$ & 17.85 \\
\hline bsNOx (EC) & g/bhp-hr & 1.94 & Distance Specific NOx (EC) & $\mathrm{g} / \mathrm{mile}$ & 17.08 \\
\hline bsNOx Corr (EC) & g/bhp-hr & 1.95 & Distance Specific NOx Corr (EC) & $\mathrm{g} / \mathrm{mile}$ & 17.20 \\
\hline bsfc & $\mathrm{lb} / \mathrm{bhp}-\mathrm{hr}$ & 0.334 & Fuel Economy & miles/gal & 2.26 \\
\hline \multicolumn{6}{|l|}{ Cycle Fuel Consumption } \\
\hline Emissions (gal) & ECU (gal) & Per Diff (\%) & & & \\
\hline 2.16 & 2.27 & -4.94 & & & \\
\hline
\end{tabular}




\section{Appendix Figure C-10 In-use Test Summary for Cummins (Bus 05108) with B20 (Soybean Oil) - Leg 2}

\begin{tabular}{|c|c|c|c|c|c|}
\hline Seq. \& Run No. & \multicolumn{2}{|c|}{ M190083 - 3} & Test Date & \multicolumn{2}{|l|}{$5-2-2008$} \\
\hline Leg & \multicolumn{5}{|c|}{ Miami 2 B20 Soybean oil Based Diesel } \\
\hline Test Location & \multicolumn{5}{|l|}{ Miami } \\
\hline Engine Manuf. & \multicolumn{2}{|l|}{ Cummins } & Engine $\mathrm{S} / \mathrm{N}$ & \multicolumn{2}{|l|}{35130187} \\
\hline Engine Model Year & \multicolumn{2}{|l|}{2005} & VIN \# & \multicolumn{2}{|c|}{ 1N90401765A140345 } \\
\hline Engine Model & \multicolumn{5}{|l|}{ ISM } \\
\hline Engine Configuration & \multicolumn{5}{|l|}{ Inline -6} \\
\hline Engine Displacement & \multicolumn{5}{|l|}{10.8} \\
\hline Aftertreatment & \multicolumn{5}{|c|}{ Donaldson - Catalyst } \\
\hline Engineer & \multicolumn{5}{|c|}{ Dan Carder } \\
\hline Ambient & \multicolumn{2}{|l|}{ Temp. } & Press & \multicolumn{2}{|l|}{$\mathrm{RH}$} \\
\hline & \multicolumn{2}{|l|}{ deg. $F$} & in $\mathrm{Hg}$ & \multicolumn{2}{|l|}{$\%$} \\
\hline Pre & \multicolumn{2}{|l|}{80} & 30.06 & \multicolumn{2}{|l|}{50} \\
\hline Post & \multicolumn{2}{|l|}{78} & 30.06 & \multicolumn{2}{|l|}{52} \\
\hline ECU Distance & Miles & 4.84 & GPS Distance & Miles & 4.64 \\
\hline ECU Inferred Work & bhp-hr & 34.59 & Data Duration & $\mathrm{s}$ & 2245.8 \\
\hline bsCO2 & g/bhp-hr & 507.7 & Distance Specific CO2 & $\mathrm{g} / \mathrm{mile}$ & 3624 \\
\hline bsNOx (Mexa) & g/bhp-hr & 2.04 & Distance Specific NOx (Mexa) & $\mathrm{g} / \mathrm{mile}$ & 14.62 \\
\hline bsNOx Corr (Mexa) & g/bhp-hr & 2.04 & Distance Specific NOx Corr (Me) & $\mathrm{g} / \mathrm{mile}$ & 14.62 \\
\hline bsNOx (EC) & g/bhp-hr & 2.00 & Distance Specific NOx (EC) & $\mathrm{g} / \mathrm{mile}$ & 14.28 \\
\hline bsNOx Corr (EC) & g/bhp-hr & 2.00 & Distance Specific NOx Corr (EC) & $\mathrm{g} / \mathrm{mile}$ & 14.28 \\
\hline Bsfc & $\mathrm{lb} / \mathrm{bhp}-\mathrm{hr}$ & 0.351 & Fuel Economy & miles/gal & 2.65 \\
\hline \multicolumn{6}{|l|}{ Cycle Fuel Consumption } \\
\hline Emissions (gal) & ECU (gal) & Per Diff (\%) & & & \\
\hline 1.82 & 1.95 & -7.07 & & & \\
\hline
\end{tabular}




\section{Appendix Figure C-11 In-use Test Summary for Cummins (Bus 05108) with B20 (Palm Oil) - Leg 1}

\begin{tabular}{|c|c|c|c|c|c|}
\hline Seq. \& Run No. & \multicolumn{2}{|c|}{ M190084 -2 } & Test Date & \multicolumn{2}{|l|}{$5-2-2008$} \\
\hline Leg & \multicolumn{5}{|c|}{ Miami 1 B20 Palm oil Based Diesel } \\
\hline Test Location & \multicolumn{5}{|l|}{ Miami } \\
\hline Engine Manuf. & \multicolumn{2}{|l|}{ Cummins } & Engine $\mathrm{S} / \mathrm{N}$ & \multicolumn{2}{|l|}{35130187} \\
\hline Engine Model Year & \multicolumn{2}{|l|}{2005} & VIN \# & \multicolumn{2}{|c|}{ 1N90401765A140345 } \\
\hline Engine Model & \multicolumn{5}{|l|}{ ISM } \\
\hline Engine Configuration & \multicolumn{5}{|l|}{ Inline -6} \\
\hline Engine Displacement & \multicolumn{5}{|l|}{10.8} \\
\hline Aftertreatment & \multicolumn{5}{|c|}{ Donaldson - Catalyst } \\
\hline Engineer & \multicolumn{5}{|l|}{ Dan Carder } \\
\hline Ambient & \multicolumn{2}{|l|}{ Temp. } & Press & \multicolumn{2}{|l|}{$\mathrm{RH}$} \\
\hline & \multicolumn{2}{|l|}{ deg. $F$} & in $\mathrm{Hg}$ & \multicolumn{2}{|l|}{$\%$} \\
\hline Pre & \multicolumn{2}{|l|}{80} & 30.05 & \multicolumn{2}{|l|}{52} \\
\hline Post & \multicolumn{2}{|l|}{84} & 30.05 & \multicolumn{2}{|l|}{52} \\
\hline ECU Distance & Miles & 4.88 & GPS Distance & Miles & 4.71 \\
\hline ECU Inferred Work & bhp-hr & 41.0 & Data Duration & $\mathrm{s}$ & 2718 \\
\hline bsCO2 & g/bhp-hr & 489.1 & Distance Specific CO2 & $\mathrm{g} / \mathrm{mile}$ & 4105 \\
\hline bsNOx (Mexa) & g/bhp-hr & 1.93 & Distance Specific NOx (Mexa) & $\mathrm{g} / \mathrm{mile}$ & 16.24 \\
\hline bsNOx Corr (Mexa) & g/bhp-hr & 1.95 & Distance Specific NOx Corr (Me) & $\mathrm{g} / \mathrm{mile}$ & 16.37 \\
\hline bsNOx (EC) & g/bhp-hr & 1.99 & Distance Specific NOx (EC) & $\mathrm{g} / \mathrm{mile}$ & 16.77 \\
\hline bsNOx Corr (EC) & g/bhp-hr & 2.01 & Distance Specific NOx Corr (EC) & $\mathrm{g} / \mathrm{mile}$ & 16.91 \\
\hline Bsfc & $\mathrm{lb} / \mathrm{bhp}-\mathrm{hr}$ & 0.338 & Fuel Economy & miles/gal & 2.34 \\
\hline \multicolumn{6}{|l|}{ Cycle Fuel Consumption } \\
\hline Emissions (gal) & ECU (gal) & Per Diff (\%) & & & \\
\hline 2.08 & 2.15 & -3.63 & & & \\
\hline
\end{tabular}




\section{Appendix Figure C-12 In-use Test Summary for Cummins (Bus 05108) with B20 (Palm}

Oil) - Leg 2

\begin{tabular}{|c|c|c|c|c|c|}
\hline Seq. \& Run No. & \multicolumn{2}{|c|}{ M190084 -3 } & Test Date & \multicolumn{2}{|l|}{$5-2-2008$} \\
\hline Leg & \multicolumn{5}{|c|}{ Miami 2 B20 Palm oil Based Diesel } \\
\hline Test Location & \multicolumn{5}{|l|}{ Miami } \\
\hline Engine Manuf. & \multicolumn{2}{|l|}{ Cummins } & Engine $\mathrm{S} / \mathrm{N}$ & \multicolumn{2}{|l|}{35130187} \\
\hline Engine Model Year & \multicolumn{2}{|l|}{2005} & VIN \# & \multicolumn{2}{|c|}{ 1N90401765A140345 } \\
\hline Engine Model & \multicolumn{5}{|l|}{ ISM } \\
\hline Engine Configuration & \multicolumn{5}{|l|}{ Inline -6} \\
\hline Engine Displacement & \multicolumn{5}{|l|}{10.8} \\
\hline Aftertreatment & \multicolumn{5}{|c|}{ Donaldson - Catalyst } \\
\hline Engineer & \multicolumn{5}{|l|}{ Dan Carder } \\
\hline Ambient & \multicolumn{2}{|l|}{ Temp. } & Press & \multicolumn{2}{|l|}{$\mathrm{RH}$} \\
\hline & \multicolumn{2}{|l|}{ deg. $F$} & in $\mathrm{Hg}$ & \multicolumn{2}{|l|}{$\%$} \\
\hline Pre & \multicolumn{2}{|l|}{83} & 30.03 & \multicolumn{2}{|l|}{50} \\
\hline Post & \multicolumn{2}{|l|}{80} & 30.01 & \multicolumn{2}{|l|}{54} \\
\hline ECU Distance & Miles & 4.82 & GPS Distance & Miles & 4.63 \\
\hline ECU Inferred Work & bhp-hr & 38.18 & Data Duration & $\mathrm{s}$ & 2413.6 \\
\hline bsCO2 & g/bhp-hr & 493.72 & Distance Specific CO2 & $\mathrm{g} / \mathrm{mile}$ & 3905 \\
\hline bsNOx (Mexa) & g/bhp-hr & 1.90 & Distance Specific NOx (Mexa) & $\mathrm{g} / \mathrm{mile}$ & 15.05 \\
\hline bsNOx Corr (Mexa) & g/bhp-hr & 1.94 & Distance Specific NOx Corr (Me) & $\mathrm{g} / \mathrm{mile}$ & 15.36 \\
\hline bsNOx (EC) & g/bhp-hr & 1.91 & Distance Specific NOx (EC) & $\mathrm{g} / \mathrm{mile}$ & 15.17 \\
\hline bsNOx Corr (EC) & g/bhp-hr & 1.95 & Distance Specific NOx Corr (EC) & $\mathrm{g} / \mathrm{mile}$ & 15.49 \\
\hline Bsfc & $\mathrm{lb} / \mathrm{bhp}-\mathrm{hr}$ & 0.342 & Fuel Economy & miles/gal & 2.46 \\
\hline \multicolumn{6}{|l|}{ Cycle Fuel Consumption } \\
\hline Emissions (gal) & ECU (gal) & Per Diff (\%) & & & \\
\hline 1.95 & 2.07 & -5.84 & & & \\
\hline
\end{tabular}

